\title{
Bibliografia historii wychowania, szkolnictwa i myśli pedagogicznej w Polsce za rok 2007 (z uzupełnieniami za lata poprzednie)
}

\begin{abstract}
WSTĘP oświaty i wychowania.

Schemat układu bibliografii:

I. Opracowania ogólne. Bibliografie

II. Rozwój oświaty, wychowania i myśli pedagogicznej

1. Opracowania ogólne

2. Okres do 1795 roku

3. Okres 1795-1918

4. Okres 1918-1939

5. Okres 1939-1945

6. Okres 1945-1989

7. Okres 1989-2007

8. Oświata polonijna
\end{abstract}

Bibliografia rejestruje druki zwarte, artykuły z czasopism i prac zbiorowych wydane w $2007 \mathrm{r}$. oraz pozycje z lat wcześniejszych, które nie znalazły się w poprzednich częściach bibliografii publikowanych na łamach „Biuletynu Historii Wychowania” od 2002 r. Nie uwzględniono recenzji opublikowanych w 2007 r., a dotyczących pozycji z lat poprzednich, które zarejestrowane były we wcześniejszych częściach bibliografii. Bibliografia ma układ według podanego niżej schematu. W poszczególnych działach i poddziałach (z wyjątkiem poddziału 5. Szkoły wyższe w Dziale III, gdzie zastosowano układ według nazw szkół oraz poddziału 2. Poszczególne biografie w Dziale IV, w którym pozycje ułożone zostały według nazwisk osób) zastosowano układ alfabetyczny według haseł autorskich lub tytułowych. Opisy w razie potrzeby zostały uzupełnione adnotacjami, a w przypadku prac zbiorowych wyszczególniono składające się na nie artykuły, dotyczące historii

III. Dzieje szkół różnych stopni

1. Szkoły podstawowe i zakłady wychowawcze

2. Szkoły średnie ogólnokształcące

3. Szkoły zawodowe

4. Zakłady kształcenia nauczycieli (z wyjątkiem szkół wyższych)

5. Szkoły wyższe

IV. Biografie

1. Zbiory życiorysów

2. Poszczególne biografie

V. Dzieje oświaty pozaszkolnej

1. Oświata dorosłych

2. Biblioteki

VI. Dzieje ruchu nauczycielskiego

1. Opracowania ogólne

2. Pamiętniki nauczycieli

VII. Organizacje młodzieżowe 


\section{WYKAZ SKRÓTÓW CZASOPISM}

Acta UL - Acta Universitatis Lodziensis

Acta Univ. Wr. - Acta Universitatis Wratislaviensis

Annales APC - Annales Academiae Padegaogiae Cracoviensis

Annales UMSC - Annales Universitatis Mariae Curie-Skłodowska

Aparat Represji w Pol. Lud. - Aparat Represji w Polsce Ludowej

Arch. Bibl. i Muz. Kośc. - Archiwa, Biblioteki i Muzea Kościelne

Arch. Hist. i Filoz. Med. - Archiwum Historii i Filozofii Medycyny

Białorus. Zesz. Hist. - Białoruskie Zeszyty Historyczne

Biul. IPN - Biuletyn Instytutu Pamięci Narodowej

Biul. Hist. Pogranicza - Biuletyn Historii Pogranicza

Biul. Hist. Wychowania - Biuletyn Historii Wychowania

Biul. Wojsk. Slużby Archiw. - Biuletyn Wojskowej Służby Archiwalnej

Bron. Zesz. Hist.-Liter. - Bronowickie Zeszyty Historyczno-Archiwalne

Ciech. Rocz. Muz. - Ciechanowiecki Rocznik Muzealny

Czasop. Prawno-Hist. - Czasopismo Prawno-Historyczne

Dzieje Najn. - Dzieje Najnowsze

Bist.-Badawczy Biul. Filat. Historyczno-Badawczy Biuletyn Filatelistyczny

Jęz. Pol. - Język Polski

Kiel. Studia Teol. - Kieleckie Studia Teologiczne

Krak. Studia Małop. - Krakowskie Studia Małopolskie

Kresy Poludn.-Wsch. - Kresy Południowo-Wschodnie

Kron. M. Łodzi. - Kronika Miasta Łodzi

Kutn. Zesz. Region. - Kutnowskie Zeszyty Regionalne

Kw. Hist. Nauki i Techn. - Kwartalnik Historii Nauki i Techniki

Kw. Hist. Żydów - Kwartalnik Historii Żydów

Lub. Rocz. Pedag. - Lubelski Rocznik Pedagogiczny

Nadwarc. Rocz. Hist.-Archiw. - Nadwarciański Rocznik Historyczno-Archiwalny

Niepodl. i Pam. - Niepodległość i Pamięć

Pr. Hum. - Prace Humanistyczne

Pr. Nauk. Akad. Im. J. Dlugosza - Prace Naukowe Akademii im. Jana Długosza

Pr. Nauk. UŚ w Katowicach - Prace Naukowe Uniwersytetu Śląskiego w Katowicach

Prz. Archeol. - Przegląd Archeologiczny

Prz. Hist.-Ośw. - Przegląd Historyczno-Oświatowy

Prz. Hum. - Przegląd Humanistyczny

Prz. Zach. - Przegląd Zachodni

Radz. Rocz. Hum. - Radzyński Rocznik Humanistyczny

Rocz. Bial.-Podl. - Rocznik Bialskopodlaski

Rocz. Bibl. Nauk. PAU i PAN Kr. - Rocznik Biblioteki Naukowej PAU i PAN w Krakowie

Rocz. Bibliot. - Roczniki Biblioteczne

Rocz. Chetm. - Rocznik Chełmski

Rocz. Gdyń. - Rocznik Gdyński

Rocz. Grudz. - Rocznik Grudziądzki

Rocz. Gniew. - Rocznik Gniewkowski

Rocz. Hist. Harcerstwa - Rocznik Historii Harcerstwa

Rocz. Hist. MHPRL - Rocznik Historyczny Muzeum Historycznego Polskiego Ruchu Ludowego

Rocz. Hum. - Roczniki Humanistyczne

Rocz. Jasiel. - Rocznik Jasielski 
Rocz. Jel.-Górs. - Rocznik Jeleniogórski

Rocz. Konin. - Rocznik Koniński

Rocz. Lubus. - Rocznik Lubuski

Rocz. Łódz. - Rocznik Łódzki

Rocz. Łubow. - Rocznik Łukowicki

Rocz. Maz. - Rocznik Mazowiecki

Rocz. Miel. - Rocznik Mielecki

Rocz. Nauk Spot. - Rocznik Nauk Społecznych

Rocz. Pedag. - Rocznik Pedagogiczny

Rocz. Pol.-Niem. - Rocznik Polsko-Niemiecki

Rocz. Przem. - Rocznik Przemyski

Rocz. PTN na Obczyźnie - Rocznik Polskiego Towarzystwa Naukowego na Obczyźnie

Rocz. Tor. - Rocznik Toruński

Rocz. Wiel. - Rocznik Wieluński

Rocz. Wołom. - Rocznik Wołomiński

Rocz. Zabłud. - Rocznik Zabłudowski

Rocz. Żyr. - Rocznik Żyrardowski

Studia Hist. - Studia Historyczne

Studia Polit. - Studia Polityczne

Studia Teol. - Studia Teologiczne

Studia Zach. - Studia Zachodnie

Studia Ziel.-Górs. - Studia Zielonogórskie

Śl. Kw. Hist. Sobótka - Śląski Kwartalnik Historyczny Sobótka

Śl. Studia Hist.-Teol. - Śląskie Studia Historyczno-Teologiczne

Tarn. Studia Teol. - Tarnowskie Studia Teologiczne

Teki Archiw. - Teki Archiwalne

Zap. Hist. - Zapiski Historyczne

Zap. Kuj.-Dobrz. - Zapiski Kujawsko-Dobrzyńskie

Zesz. Hist. Politech. Łódz. - Zeszyty Historyczne Politechniki Łódzkiej

Zesz. Liter. - Zeszyty Literackie

Zesz. Nauk. UJ - Zeszyty Naukowe Uniwersytetu Jagiellońskiego

Żyr. Rocz. Muz. - Żyrardowski Rocznik Muzealny 


\section{OPRACOWANIA OGÓLNE. BIBLIOGRAFIE}

1. APANEL Danuta, Dąbrowska Joanna: III Walne Zebranie Członków Towarzystwa Historii Edukacji. Biul. Hist. Wychowania. 2005/2006 [nr] 1/2 [dr.:] 2007 s. 259-260.

Warszawa, 24 X 2005 r.

2. BIBLIOGRAFIA „Przeglądu Historyczno-Oświatowego” za 60 lat działalności wydawniczej (1947-2007). Oprac. Iwona Czarnecka i Karol Poznański. Prz. Hist.-Ośw. R. 50: 2007 nr 4 s. $3-132$.

3. BIBLIOGRAFIA dziejów oświaty i wychowania w Galicji 1772-1918. Cz. 2: Źródła drukowane. Pod red. Andrzeja Meissnera i Juliana Dybca. Rzeszów 2007 Wydaw. Uniw. Rzeszowskiego ss. 336.

Cz. 1. 1992.

4. BIBLIOGRAFIA historii wychowania, szkolnictwa i myśli pedagogicznej w Polsce za rok 2003 (z uzupełnieniami za poprzednie lata). Oprac. Anna Gruca. Biul. Hist. Wychowania. 2005/2006 [nr] 1/2 [dr.:] 2007 s. 147-192.

Toż za rok 2004. Tamże s. 193-247.

5. GLÜCK Helmut, Schröder Konrad: Deutschlernen in den polnischen Ländern vom 15. Jahrhundert bis 1918. Eine teilkommentierte Bibliographie. Wiesbaden 2007 Harrasowitz ss. XLVIII, 271. (Fremdsprachen in Geschichte und Gegenwart; 2).

6. GULCZYŃSKA Justyna: Konferencja w Kamieniu Śląskim. Biul. Hist. Wychowania. 2005/2006 [nr] 1/2 [dr.:] 2007 s. 250-252.

22-23 VI 2006 r.; nt.: Wkład towarzystw oświatowych w rozwój kultury europejskiej - przeszłość - teraźniejszość - przyszłość.

7. HAJDUK Łukasz: Stan i perspektywy rozwoju refleksji nad edukacją dorosłych. Konferencja jubileuszowa z okazji 60-lecia powołania w Uniwersytecie Jagiellońskim Katedry Oświaty i Kultury Dorosłych. Kraków, 24-25.04.2006 r. Rocz. Pedag. T. 30: 2007 s. 83-86.

8. KALINOWSKI Marian, Pełka Jerzy: Zarys dziejów resocjalizacji nieletnich. Wyd. 2 rozsz. Warszawa 2003 Wydaw. Akad. Pedagogiki Specjalnej ss. 367.

Rec.: Pękowska Marzena, Prz. Hist.-Ośw. R. 50: 2007 nr 3 s. 201-203.

Wyd. 1. 1996.

9. KIERUZEL Marcin: Ważny element tożsamości miasta. Muzeum Oświaty Ziemi Łódzkiej. Kron. M. Łodzi. 2007 [nr] 2 s. 49-54.

Powstało w $1983 \mathrm{r}$.

10. KORZENIECKA-BONDAR Alicja: Odejście od przeciętności - XX-lecie Letniej Szkoły Młodych Pedagogów. Rocz. Pedag. T. 30: 2007 s. 193-203.

Organizowanej przez Polski Komitet Nauk Pedagogicznych PAN.

11. KWIATKOWSKA Henryka: Sprawozdanie z działalności Komitetu Nauk Pedagogicznych PAN za rok 2006. Rocz. Pedag. T. 30: 2007 s. 47-63.

12. RATAJCZAK Krzysztof: „Milites dei” - o interdyscyplinarności badań nad dziejami zakonów rycerskich na ziemiach polskich i w regionie nadbałtyckim z perspektywy historii wychowania. W: Mundus hominis. Cywilizacja, kultura, natura. Wokół interdyscyplinarności badań historycznych. Pod red. Stanisława Rosika i Przemysława Wiszewskiego. Wrocław 2006 s. 501-513. 
13. SMOŁALSKI Antoni: Pedeutologia historyczna. Wrocław 2006 MarMar Marian Kaczorowski ss. 147.

Rec.: Mauersberg Stanisław, Prz. Hist.-Ośw. R. 50: 2007 nr 1/2 s. 227-228.

14. SZELOCH Ewa: Żydzi i ich rola w dziejach Polski w syntezach i podręcznikach szkolnych Adama Szelągowskiego. W: Wielokulturowe środowisko historyczne Lwowa w XIX i XX w. T. 5. Pod red. Jerzego Maternickiego, Leonida Zaszkilniaka. Rzeszów 2007 s. 450-463.

15. WIECZOREK Barbara: Bibliografia pedagogiki 2005 (Książki wydane w Polsce: wybór). Rocz. Pedag. T. 30: 2007 s. 223-229.

16. WIERZBICKA Beata: Materiały rękopiśmienne, źródła drukowane oraz zestawienie literatury dotyczącej kolegium oo. Pijarów w Podolińcu. Almanach Sądecki. R. 16: 2007 nr 1/2 s. 19-24.

\title{
II. ROZWÓJ OŚWIATY, WYCHOWANIA I MYŚLI PEDAGOGICZNEJ
}

\author{
1. Opracowania ogólne
}

17. ADAMCZYK Jerzy: Instytucja prefekta szkolnego w diecezjalnym ustawodawstwie synodalnym w Polsce w latach 1983-2005. Resovia Sacra. R. 13: 2006 s. 335-348, rias.

18. BIERUŃ. Monografia historyczna. Pod red. Ryszarda Kaczmarka i Jerzego Myszora. Bieruń 2007 Bieruński Ośr. Kultury ss. 421, nlb. 2, il., mapy.

Z treści: Fic Maciej: Szkolnictwo s. 359-394.

19. BOGUS Marzena: Kotulowie i ich działania oświatowe na Śląsku Cieszyńskim w XIX i XX wieku. Ostrava 2006 Filozofická Fakulta Ostravská Univerzity ss. 279, tabl. 16.

Rec.: Kubacz Adam, Śl. Kw. Hist. Sobótka. R. 62: 2007 nr 4 s. 531-533.

20. BRESLAUER Schulen. Geschichte und Architektur. Hrsg. von Maria Zwierz. Wrocław 2005 Muzeum Architektury ss. 255, tabl. 16, il.

Tyt. oryg.: Wrocławskie szkoły. Historia i architektura. Wrocław 2004.

21. ČEPIL' Mariâ: Formuvannâ nacional'noi svìdomosti učnivs'koi molodì Haličini (1848-1939 rr.). Drohobič 2005 Kolo ss. 539, nlb. 1, il.

Rec.: Kucha Ryszard, Lub. Rocz. Pedag. T. 26: 2006 s. 265-266.

22. CWER Andrzej: Wołanie o szkołę rycerską w Rzeczypospolitej. Prz. Hist.-Ośw. R. 50: 2007 nr 3 s. 5-128.

$\mathrm{XV}-\mathrm{XX}$ w.

23. CZARNECKA Ewa: Wychowanie przez sztukę w działalności instytucji oświatowo-wychowawczych w Płocku w latach 1900-1939. Płock 2006 Wydaw. Państ. Wyższej Szkoły Zawodowej ss. 244. PWSZ w Płocku. (Monografie; t. 3).

24. CZARNECKA Iwona: Sprawozdanie z pierwszego biennale historyków edukacji na temat: „Być dzieckiem w XVIII-XIX wieku”, Święta Katarzyna, 25-26 września 2006 roku. Prz. Hist.-Ośw. R. 50: $2007 \mathrm{nr}$ 1/2 s. 247-250. 
25. DOLEŽAL Horst: Oberschlesische Studenten an der medizinischen Fakultät der Universität Wien in den Jahren 1818 bis 1938. W: Górny Śląsk - dokumentowanie dziejów lecznictwa ze szczególnym uwzględnieniem ziem dawnych księstw cieszyńskiego i opawskiego. Praca zbiorowa. Pod red. Jerzego Mariana Dyrdy i Joanny Miozgi. Katowice 2007 s. 154-195.

26. DUCH i czas. Materiały do dziejów Szubina i Ziemi Szubińskiej. [Cz.] 3. Red. i oprac. graf. Kamila Czechowska, Mirosław Rzeszowski. Szubin 2007 MZS; K-PTK ss. 159, il. Muzeum Ziemi Szubińskiej im. Zenona Erdmanna w Szubinie oraz Kujawsko-Pałuckie Tow. Kult. w Szubinie.

Z treści: Andruszkiewicz Jacek: Zakład dla Nieletnich w Szubinie w latach 1888-1989 (zapiski historyczno-sentymentalne) s. 7-22; Polańska Mariola: Szkoła tysiąclecia w Szubinie 1962-2007 s. 90-94; Zaremba Urszula: Zygmunt Bałka (1904-1975) nauczyciel, kierownik szkoły w Buszkowie s. 111-112; Polańska M.: Idzi Domiński (1932-1983) pedagog, dyrektor, działacz s. 120-122; Duda Anna: Aleksander Kazimierz Waligórski (1932-2005) magister ekonomii, pedagog, dyrektor Technikum Ekonomicznego - pierwszej szkoły średniej w Szubinie, członek jednej z pierwszych aresztowanych przez Niemców rodzin w czasie II wojny światowej w Szubinie s. 142-148.

27. DZIĘGIELÓW 1305-2005. Zespół red. Zofia Fober, Tomasz Lenkiewicz, Katarzyna Bogdał; przy rozdz. współpr. Emil Gajdacz. Dzięgielów 2007 Centrum Misji i Ewangelizacji Wydaw. „Warto” ss. 117, nlb. 2, il.

Z treści: „Aż dotąd pomagał nam Pan” czyli Zakłady Opiekuńczo-Wychowawcze i Diakonat Żeński Eben-Ezer s. 22-29; „By język giętki powiedział wszystko co pomyśli głowa” czyli dzięgielowskiej oświaty s. 54-67; Prawdziwe przytulisko czyli Dom Dziecka s. 68-73.

28. EDUKACJA. Konteksty historyczno-pedagogiczne. Red. nauk. Mirosław Piwowarczyk. Kraków 2007 Oficyna Wydawnicza „Impuls” ss. 201, nlb. 3.

Z treści: Piwowarczyk M.: Wstęp s. 7-11; Rok Bogdan: Wychowanie wiejskich dzieci w świetle poradników Józefa Legowicza s. 83-95; Walasek Stefania: Nauczyciele i ich rola w edukacji społeczeństwa byłej guberni wileńskiej w XIX i na początku XX wieku s. 97-109; Skotnicka Małgorzata: Misja kulturalna inteligencji polskiej w dwudziestoleciu międzywojennym. Casus Jakuba Mortkowicza i Antoniego Osuchowskiego oraz Liceum Krzemienieckiego s. 111-122; Piwowarczyk M.: Towarzystwa i organizacje kulturalno-oświatowe społeczności lokalnej Kalisza w II Rzeczypospolitej s. 141-153; Malik Małgorzata: Walka z analfabetyzmem na Dolnym Śląsku w latach 1945-1951 s. 155-165.

29. GMINA Pokrzywnica. Z historii, oświaty, kultury i samorządu gminnego. Praca zbior. pod red. Mariana Kalinowskiego; aut. Elżbieta Barbarska [i in.]. Pokrzywnica-Otwock 2007 Inwestprojekt-System ss. 182, tabl. 2, il., mapy.

Z treści: Szkolnictwo s. $75-142$.

30. IDEAŁY wychowania i wzory osobowe narodu polskiego w XIX i XX wieku. T. 1. Pod red. Elwiry J. Kryńskiej. Białystok 2006 Trans Humana Wydaw. Uniwersyteckie ss. 270, il.

Z treści: Kryńska E. J.: Ideał wychowania a wzór osobowy. Niektóre typy uznawanych wzorów osobowych w XIX i XX wieku s. 23-32; Kryński Andrzej: Idea narodowa w działalności misyjnej Maksymiliana Ryłło SJ: 1802-1848 s. 35-45; Konopacki Artur: Wychowanie ziemiaństwa polskiego na Litwie w XIX wieku w świetle pamiętnika Gabrieli Puzyniny s. 46-52; Dąbrowska Joanna: Kobieta aktywna zawodowo w XIX wieku na przykładzie Klementyny z Tańskich Hoffmanowej s. 53-65; Stawiak-Ososińska Małgorzata: Etos Polki w okresie międzypowstaniowym (1811-1862) s. 66-75; Walewander Edward: Etos wychowania w życiu w działalności pasterskiej Biskupa Lubelskiego Mariana Leona Fulmana s. 76-80; Kosińska Marzena: Bogdan Jański [1807-1840] - przyjaciel i duchowy przewodnik artystów s. 81-89; Markiewiczowa Hanna: Etos dobroczynności w pracach Warszawskiego Towarzystwa Dobroczynności s. 90-99; Galek Czesław: Ideały wychowawcze Bolesława Prusa s. 100-111; Kula Ewa: Wpływ ideologii pozytywizmu na poglądy pedagogiczne nauczycieli zatrudnionych w rządowych szkołach średnich Królestwa Polskiego w latach 1862-1873 s. 112-121; Pisulińska Joanna: Bohaterowie żydowscy w XIX-wiecznych syntezach i podręcznikach dziejów Polski s. 122-132; Apanel Danuta: Patriotyczna postawa Dzieci Wrzesińskich jako swoisty etos wychowania w dziejach narodu polskiego s. 133-142; Nawrot Monika: Wartości i tradycje narodowe w nauczaniu domowym 
w Wielkopolsce w drugiej połowie XIX i początkach XX wieku w świetle ówczesnej prasy s. 145-163; Burzyńska-Wentland Lidia: „Ojczyzna, Nauka, Cnota” etosem wychowawczym młodzieży polskiej z Prus Zachodnich w XIX i na początku XX wieku s. 164-173; Szewczuk Dariusz: Wychowawcze aspekty działalności ochronek na Lubelszczyźnie w początkach XX wieku s. 174-184; Koszyk Irena, Białokur Marek: Maria Skłodowska-Curie (1867-1934). Wzór ponadczasowych postaw i ideałów s. 185-195; Pękowska Marzena: Wkład nauczycieli Zakładu dla Głuchoniemych we Lwowie w tworzeniu modelu nauczyciela szkoły specjalnej (1830-1914) s. 196-205; Kurek Jacek: Perła w koronie. U źródeł górnośląskiego etosu wychowania s. 206-215; Zakrzewska Aldona: Józef Piłsudski - inicjator i przywódca ruchu strzeleckiego s. 216-230; Frątczak Kornelia: Józef Piłsudski - bojownik o wyzwolenie Ojczyzny - romantyk nowego pokolenia s. 231-241; Wróblewska Urszula: Etos wychowania tatarskiego na przykładzie Aleksandra Sulkiewicza s. 242-252; Marszałek Katarzyna: Źródła etosu wychowania harcerskiego s. 253-261.

Toż. T. 2. Białystok 2006 ss. 425, il.

Z treści: Szablicka-Żak Jolanta: Spory o koncepcje wychowania w debatach parlamentarnych w Drugiej Rzeczypospolitej s. 13-21; Magiera Elżbieta: Stosunek wychowania państwowego do wychowania narodowego w opinii twórców ideologii wychowawczej sanacji s. 22-30; Mauersberg Stanisław: Józef Piłsudski - wzór osobowy nakreślony na podstawie czynów, pism i przemówień s. 31-45; Wyszczelski Lech: Józef Piłsudski o wychowaniu wojskowym s. 46-55; Tomaszewski Roman: Etos polskiego wychowania wojskowego w XX wieku s. 56-66; Osiński Zbigniew: Nowy człowiek i nowy obywatel - wychowawcza wizja Janusza Jędrzejewicza s. 67-80; Juchcińska Kamila: Udział Janusza Jędrzejewicza w wypracowaniu i upowszechnianiu doktryny wychowania państwowego s. 81-92; Maliszewski Krzysztof: Wolna osobowość. Aksjocentryczny ideał człowieka w międzywojennej pedagogice kultury s. 93-99; Furmańska Małgorzata: „Czas wyzwolić rozum” s. 100-106; Kulbaka Jacek: Maria Grzegorzewska [1888-1967] i jej wizja dobrego nauczyciela s. 107-117; Bednarzak-Libera Mirosława: Ignacy Solarz (1891-1940) ludowiec - wychowawca młodzieży wiejskiej i spółdzielca s. 118-148; Karolewicz Grażyna: Ojciec Jacek Woroniecki (1878-1949) jako wychowawca inteligencji katolickiej s. 149-158; Białokur Marek: W służbie narodu polskiego. Joachim Bartoszewicz na polu działalności wychowawczej i patriotycznej s. 159-169; Puchowska Małgorzata: „Europejczyk, et quidem Polak”. Z dziejów edukacji w szkołach jezuickich Drugiej Rzeczypospolitej s. 170-182; Wysocki Roman: Rola polskich wzorców narodowych w procesie kształtowania postawy młodzieży ukraińskiej w Drugiej Rzeczypospolitej s. 183-194; Glimos-Nadgórska Anna: Górnośląskie założenia wychowawcze czasów pruskich a cele wychowania państwowego realizowane w szkolnictwie powszechnym międzywojennego województwa śląskiego s. 195-206; Szarkowska Agnieszka: Etos wychowawczy szkół prywatnych w województwie białostockim w Drugiej Rzeczypospolitej s. 207-226; Pałgan Iwona: Radomscy nauczyciele szkół średnich ogólnokształcących jako lokalni wychowawcy Polski Odrodzonej s. 227-234; Litwiński Robert: W służbie państwa i obywateli. Wzorzec osobowy policjanta w Drugiej Rzeczypospolitej s. 235-245; Walczak Marian: Meandry wychowawcze okresu okupacji 1939-1945 s. 249-250; Kubis Barbara: Pomniki w słowach - o nieznanych bohaterach drugiej wojny światowej s. 251-260; Sadowska Joanna: Próby kształtowania młodego pokolenia w PRL na przykładzie działań ZMS s. 261-270; Małachowski Ryszard: Etos działalności wychowawczej księdza Aleksandra Zienkiewicza w warunkach zmian ustrojowych państwa polskiego s. 271-283; Skoneczny Tomasz: Wartości wychowania chłopskiego w okresie transformacji ustrojowych przełomu lat czterdziestych i pięćdziesiątych XX wieku w Polsce s. 284-294; Jakubowicz Ewa: Sprawa wychowania na Zjeździe Oświatowym 2-5 maja 1957 roku s. 295-301; Raźniewska Joanna: Uczyć dobrej roboty na co dzień - postać i koncepcje postaw Tadeusza Kotarbińskiego s. 302-310; Czarnecka Iwona: Współpraca Polskiego Związku Głuchych i Sekcji Szkolnictwa Specjalnego ZNP na rzecz osób głuchych s. 311-318.

Rec. Skreczko Adam, Prz. Hist.-Ośw. R. 50: 2007 nr 3 s. 207-209.

31. JUCHCIŃSKA-GIŁKA Kamila, Nawrot-Borowska Monika: Pierwsze Biennale Historyków Edukacji „Być dzieckiem w XVIII-XX wieku” Kielce-Święta Katarzyna, 25-26 września 2006 r. Biul. Hist. Wychowania. 2005/2006 [nr] 1/2 [dr.:] 2007 s. 253-257.

32. KIERNIKOWSKI Paweł: Organizacja oświaty w Chełmie w latach 1918-1944. Rocz. Chetm. T. 10: 2006 s. 223-260.

33. KOŁODZIEJ Katarzyna: Dzieje szkół prowadzonych przez Zgromadzenie Sióstr Służek Najświętszej Maryi Panny Niepokalanej w Sandomierzu. W 85 rocznicę działalności oświatowej Zgromadzenia w Sandomierzu i z okazji jubileuszu 10-lecia Katolickiego Liceum Ogólnokształcą- 
cego im. św. Jadwigi Królowej w Sandomierzu. Sandomierz 2007 Wydaw. Diec. i Drukarnia ss. 238 , il.

34. KRAWIEC Jan: Działalność duszpastersko-wychowawcza salezjanów w Pogrzebieniu w latach 1930-2005. W: Dzieje salezjanów na ziemi raciborskiej. Kraków 2006 ss. 17-142.

35. KREJPOWICZ Sławomir: Żyrardowskie Towarzystwo „Wychowanie”. Żyr. Rocz. Muz. R. 6: $2006 \mathrm{nr} 7$ s. $47-52$.

Od 1908 r. do pocz. 1. 30. XX w.

36. KSZTAŁCENIE oficerów korpusu technicznego Polskiej Marynarki Wojennej w latach 1931-2006. Red. nauk. Jerzy Będźmirowski. Gdynia 2006 Akad. Marynarki Wojennej im. Bohaterów Westerplatte ss. 131, nlb. 2. Akad. Marynarki Wojennej im. Bohaterów Westerplatte.

Treść: Nawrot Dariusz: Powstanie, rozwój i działalność Korpusu Technicznego Oficerów Marynarki Wojennej II RP s. 3-34; Sługocki Józef K.: Wydział Techniczny Szkoły Podchorążych Marynarki Wojennej w latach 1931-1939 s. 35-59; Będźmirowski J.: Udział flot sojuszniczych Francji i Wielkiej Brytanii w kształceniu oficerów Korpusu Technicznego PMW s. 60-72; Zalewski Bogdan: Kształcenie oficerów technicznych Marynarki Wojennej i rozwój morskiej myśli technicznej w Polsce po II wojnie światowej s. 73-94; Będźmirowski J.: Współpraca Marynarki Wojennej PRL z Marynarką Wojenną ZSRR w zakresie kształcenia i szkolenia specjalistycznego oficerów Korpusu Technicznego s. 95-108; Korczewski Zbigniew: Dzień dzisiejszy i perspektywy rozwojowe Wydziału Mechaniczno-Elektrycznego Akademii Marynarki Wojennej s. 109-131.

37. KUCZ Anna: „Manuductio ad amplectendam doctrinam et virtytem” - o umiłowaniu nauki i cnoty w łacińskiej szkole na Śląsku. Śl. Studia Hist.-Teol. T. 39: 2006 z. 2 s. 421-428, somm.

XV-XVII w.

38. KUPISIEWICZ Małgorzata: Polskie dylematy oświatowe w latach 1970-2006. Próba retrospektywnego spojrzenia na podstawie wywiadów prasowych prof. Czesława Kulisiewicza. Warszawa-Pułtusk 2007 Akad. Hum. im. Aleksandra Gieysztora ss. 282. (Biblioteka „Artes Liberale” Akademii Humanistycznej im. Aleksandra Gieysztora; 3).

39. LEGNICKIE Conversatorium Organowe 1986-2005. Materiały z sesji naukowej Conversatorium Organowe a poziom kształcenia młodych organistów, towarzyszącej XX Legnickiemu Conversatorium Organowemu, Legnica, 8 września 2005. Red. nauk. Marcin Tadeusz Łukaszewski. Warszawa-Legnica 2006 Wydaw. AM im. F. Chopina; Biuro Organizacyjne Legnickiego Conversatorium Organowego. LCK im. H. Karlińskiego ss. 118. Akad. Muzyczna im. Fryderyka Chopina w Warszawie, Legnickie Centrum Kultury im. Henryka Karlińskiego, Legnickie Conversatorium Organowe.

Z treści: Łukaszewski M. T.: Organowa twórczość kompozytorów warszawskich w latach 1945-2005 i jej zastosowanie w pedagogice na przykładzie 20-letniej działalności „Conversatorium Organowego” w Legnicy s. 30-44; Kruzel-Sosnowska Marietta: Wpływ konkursów organowych organizowanych w ramach „Legnickiego Conversatorium Organowego" na poziom nauczania w średnich szkołach muzycznych s. 45-53; WęgrzynKlisowska Walentyna: Legnicka szkoła organistowska w latach 1891-1944 s. 54-59; Dziadek Magdalena: Początki akademickiej organistyki w Polsce s. 60-67; Wygranienko Rostislaw: Muzyka krajów Europy Wschodniej jako katalizator idei integracji w kształceniu młodych organistów s. 68-72; Kunecka Krystyna, Grabska Teofila: „Legnickie Conversatorium Organowe” 1986-2005 - Dokumentacja s. 73-118.

40. MICHNA Gustaw, Faruga Andrzej: Od Cieszyna do Olsztyna. Z przeszłości rolnictwa Ziemi Cieszyńskiej i Wyższego Szkolnictwa Rolniczego Warmii i Mazur (XIX i XX wiek). Olsztyn 2006 Warmińsko-Mazurskie Koło Macierzy Ziemi Cieszyńskiej ss. 114, il.

Z okazji 120-lecia Macierzy Szkolnej dla Księstwa Cieszyńskiego (1885-2005).

41. MOŚ Wojciech B[ogusław], Soszyński Włodzimierz: Polskie szkolnictwo wojskowe 1908-1939. Odznaki, emblematy, dokumenty. Kraków-Bytom 2007 Avalon; we współpr. z Muzeum Górnośląskim ss. 134, il. 
42. NASALSKA Ewa: Wysiedlenie Niemców jako element szkolnej edukacji historycznej w latach 1956-2006. Rocz. Pol.-Niem. [T.] 15: 2007 s. 79-104, sum.

43. NAUCZANIE muzyki na Pomorzu i Kujawach. Pod red. Aleksandry Kłaput-Wiśniewskiej. Bydgoszcz 2007 Wydaw. Uczelniane AM im. F. Nowowiejskiego ss. 188, il. Akad. Muzyczna im. Feliksa Nowowiejskiego w Bydgoszczy. (Prace Zbiorowe AM; nr 25).

Treść: Szwankowski Jerzy: Kształcenie muzyczne uczniów Królewskiego Katolickiego Gimnazjum w Chojnicach w latach 1815-1920 s. 9-19; Rondomańska Zenona: Nauczyciele z Pomorza pracujący w szkolnictwie polskim na Warmii w okresie międzywojennym s. 21-41; Kłaput-Wiśniewska A.: Szkolenie nauczycieli śpiewu i nadzór metodyczny nad nauczaniem muzyki w szkolnictwie powszechnym w Bydgoszczy w latach 1920-1939 s. 43-60; Kuczma Rajmund: Nauczanie muzyki w etatowych orkiestrach wojskowych w latach 1920-1939 s. 61-69; Ryszkowska Eulalia, Ryszkowska Joanna: Pomoce do nauczania muzyki wydane przed 1945 rokiem w zbiorach Wypożyczalni Zbiorów Dźwiękowych WiMBP w Bydgoszczy s. 71-86; Wróbel-Sawosz Danuta: Działalność Szkoły Muzycznej w Nakle w czasie okupacji niemieckiej (1939-1945) s. 87-95; Sienkiewicz-Bloch Eleonora: Okręgowy Zespół Metodyczno-Programowy Szkolnictwa Artystycznego w Bydgoszczy (1956-1985) s. 97-110; Weber Alicja: Edukacyjno-artystyczna działalność Społecznego Ogniska Artystycznego nr 1 w Bydgoszczy w latach 1954-1974 s. 111-150; Zielińska Zofia: Ognisko muzyczne w Mogilnie. Historia i podstawy prawne działalności Ogniska s. 151-164; Grzywacz Piotr: Nauka gry na rogu myśliwskim w Zespole Szkół Leśnych i Agrotechnicznych w Tucholi s. 165-188.

44. NIKITENKO Danuta, Nikitenko Włodzimierz: Szkolnictwo ukraińskie w Legnicy. Prz. Zach. R. 63: 2007 nr 3 s. 166-187, sum.

Od 1956 r.

45. PAŃSTWO a wychowanie. Idee - mity - stereotypy. Praca zbior. pod red. Andrzeja Dymera i Tomasza Sikorskiego. Szczecin 2005 Print Group Daniel Krzanowski ss. 340, nlb. 1, il. Centrum Edukacyjne Archidiec. Szczecińsko-Kamieńskiej, Inst. Pedagogiki Uniw. Szczecińskiego.

Z treści: Strzelecki Michał: Ideały wychowania obywatelskiego w interpretacjach polskiej myśli społeczno-politycznej okresu II Rzeczypospolitej s. 11-32; Wójcik Alicja: Ideały wychowania narodowego w myśli politycznej ludowców do odzyskania niepodległości w 1918 roku s. 33-48; Wojdyło Witold: Wychowanie religijne i jego implikacje w myśli politycznej obozu narodowego 1918-1939 s. 49-57; Radomski Grzegorz: Wychowawcze aspekty działalności samorządu terytorialnego w interpretacjach ruchu narodowego w XX wieku s. 59-74; Jakubiak Krzysztof: Główne wartości piłsudczykowskiej ideologii państwowej i jej wpływ na kształtowanie doktryny wychowawczej sanacji s. 75-87; Jakubiak K.: Udział społeczno-kulturalnych i pedagogicznych wydawnictw periodycznych w wypracowywaniu i upowszechnianiu ideologii wychowawczej sanacji s. 89-93; Sikorski T.: Obywatel-Polak. Refleksja nad ideałem wychowania państwowego w publicystyce konserwatywnej II Rzeczypospolitej s. 95-121; Macała Jarosław: Wychowanie państwowe w państwach faszystowskich w opinii środowisk katolickich II RP s. 123-140; Brodacka-Adamowicz Ewa: Podręczniki do nauki języka polskiego dla szkoły średniej ogólnokształcącej autorstwa Stanisława Łempickiego i Henryka Gaertnera s. 143-160; Wiśniewska Małgorzata: Wychowanie państwowe młodzieży żeńskiej do wybuchu II wojny światowej s. 161-175; Magiera Elżbieta: Wychowanie państwowe w szkolnictwie powszechnym okresu międzywojennego (1918-1939) s. 177-187; Magiera E.: Wychowanie państwowe wobec doktryny wychowawczej Kościoła katolickiego w II Rzeczypospolitej s. 189-200; Mazur Mariusz: Koncepcja obywatela na łamach prasy okresu stalinowskiego s. 201-217; Krasucki Eryk: Młodzi obywatele - dzieci i młodzież na polskich znaczkach pocztowych (1947-1956) s. 219-229; Cichosz Wojciech: Zarys dziejów wychowania katolickiego w Polsce s. 231-244.

46. PARTEKA Witold: Szkolnictwo oficerskie Polskiej Marynarki Handlowej w Gdyni w latach 1930-2007. Rocz. Gdyń. Nr 19: 2007 s. 91-106.

47. PIERWSZA księga jubileuszowa wsi Lubatowa wydana w 630-lecie jej istnienia. Red. Janusz Podlaszczak. Rzeszów 2006 Poligrafia Wyższego Seminarium Duchownego ss. 368, tabl. 48 , il.

Z treści: Matusik Grażyna, Owsiana Danuta, Ceglarz Andrzej: Oświata w Lubatowej na przestrzeni XX wieku s. 149-182; Podlaszczak J.: Oświata, kultura i sport s. 283-298. 
48. PILAREK Sławomir: Inicjatywy Szkolnego Związku Sportowego związane z działalnością programową w Polsce, ze szczególnym uwzględnieniem Górnego Śląska i Zagłębia Dąbrowskiego w latach 1957-1998 (zarys problematyki). W: Szkice z historii oraz organizacji kultury fizycznej i turystyki in memoriam Stanisław Podobiński et Andrzej Wasiak. Praca zbior. pod red. Andrzeja Nowakowskiego. Wadowice 2007 s. 31-46.

49. POWIĄZANIA rodzinne wśród twórców polskiej teorii i praktyki edukacyjnej. Pod red. Wiesława Jamrożka [i in.]. Poznań 2007 Wydaw. Poznańskie ss. 311.

Treść: Szulakiewicz Władysława: Biografistyka w polskiej historiografii edukacyjnej s. 9-33; Ratajczak Krzysztof: Jadwiga i Jagiełło a odnowienie Uniwersytetu Krakowskiego 1390-1400 s. 35-44; Winiarz Adam: Eustachego i Marianny Potockich troska o edukację swoich dzieci s. 45-55; Gawlik Stanisław: Uwarunkowania rodzinne działalności pedagogicznej Grzegorza Piramowicza s. 57-64; Wolter Edyta: Ekologiczne przesłanki w twórczości naukowej Jana i Jędrzeja Śniadeckich s. 65-69; Apanel Danuta: Wkład rodziny Czackich w rozwój polskiej teorii i praktyki edukacyjnej s. 71-79; Dąbrowska Joanna Elżbieta: W kręgu Hoffmanowej... s. 81-92; Kabacińska Katarzyna: Działalność edukacyjna wybranych przedstawicieli rodu Potockich s. 93-98; Michalska Iwonna, Michalski Grzegorz: Działalność rodziny Arctów na rzecz edukacji s. 99-110; Pękowska Marzena: Powiązania rodzinne wśród nauczycieli lwowskich szkół dla głuchoniemych i niewidomych dzieci (1830-1939) s. 111-119; Kabzińska Łucja, Kabziński Krzysztof: Andrzej Samulowski (1840-1928) jako przedstawiciel rodu warmińskich działaczy kulturalno-oświatowych s. 121-135; Gulczyńska Justyna: Społeczno-edukacyjna działalność sióstr [Marii, Lucyny i Zofii] Sokolnickich s. 137-145; Sapia-Drewniak Eleonora: Wpływ pokolenia dziadków na kształtowanie się drogi życiowej nauczycieli śląskich s. 147-155; Wałęga Agnieszka: Środowisko rodzinne a działalność pedagogiczna rodzeństwa Wandy, Stefana i Henryka Szumanów s. 157-169; Wira-Świątkowska Katarzyna: Rodzina w kontekście wyborów życiowych Marii WeryhoRadziwiłłowiczowej s. 171-177; Łozowska Kamilla: Społeczno-edukacyjna aktywność rodziny Krzywickich s. 179-186; Kula Ewa: Życie rodzinne nauczycieli męskich szkół średnich w Królestwie Polskim w latach 1862-1873 (na przykładzie nauczycieli gimnazjów w Kielcach i Radomiu) s. 187-195; Stopińska-Pająk Agnieszka: Izabella Moszczeńska i jej rodzina - w służbie polskiej oświaty s. 197-204; Koźmian Danuta: Rodzina i jej wpływ na poglądy i działalność Heleny Witkowskiej (1870-1938) i Janusza Jędrzejewicza (1885-1951) s. 205-215; Posłuszna Małgorzata: Wkład Teodora i Wacława Męczkowskich w rozwój polskiej pedagogiki s. 217-225; Kowalska Joanna: Społeczno-edukacyjna działalność Ludwika Posadzy i Stefanii Marianny z Marciszewskich Posadzowej s. 227-230; Jałmużna Tadeusz: Dom rodzinny i jego oddziaływanie na zainteresowania i działalność pedagogiczną Stanisława Mariana Dobrowolskiego s. 231-239; Hubicka Sylwia Ewa: Rzeczpospolita Lutycka - marzenie Olgi i Andrzeja Małkowskich s. 241-251; Jamrożek W.: Ignacy i Zofia Solarzowie - twórcy wiejskiego uniwersytetu ludowego s. 253-258; Waszczykowska Sylwia: Ewa i Feliks Przyłubscy oraz Janina i Antoni Maćkowiakowie na rzecz edukacji wczesnoszkolnej s. 259-264; Stolińska-Pobralska Nella, Pobralski Jerzy: Biograficzne uwarunkowania systemu wychowawczego Kazimierza Lisieckiego s. 265-272; Głowacka-Sobiech Edyta: „Kamykowe małżeństwo”. O Janinie i Aleksandrze Kamińskich s. 273-280; Jałmużna Tomasz: Niepubliczne średnie szkoły ogólnokształcące w Łodzi prowadzone przez rodziny - przeszłość i teraźniejszość s. 281-285; Buczek Katarzyna: Lwowsko-krakowskie korzenie Jana Hulewicza - zarys problemu s. 287-293; Kusztelak Andrzej: Wkład par małżeńskich w rozwój teorii i praktyki edukacyjnej w polskich szkołach poza granicami kraju s. 295-303; Ryś Jan, Ślęczka Ryszard: Studenci z rodzin nauczycielskich w Akademii Pedagogicznej w Krakowie w latach 1999-2004 s. 305-311.

50. ROLA oświaty i szkolnictwa w procesie kształtowania się świadomości narodowej na pograniczu polsko-litewsko-białoruskim. Red. Wojciech Śleszyński. Białystok 2007 Wydaw. Prymat Mariusz Śliwowski ss. 384, nlb. 4, il. Inst. Historii Uniw. w Białymstoku. (Wspólne Dziedzictwo Ziem Północno-Wschodnich Dawnej Rzeczypospolitej; t. 6).

Materiały z międzynarodowej konferencji, 16-17 XI 2007 r.

Tom dedykowany prof. Zofii Tomczonek.

Z treści: Smolarczyk Andrzej: Zofia Tomczonek - badacz kresów północno-wschodnich II Rzeczypospolitej s. 11-14; Smolarczyk A.: Wykaz prac Zofii Tomczonek s. 15-19; Łopatecki Karol: Marzenia o nowej utopii - rola edukacji w kształtowaniu tożsamości narodowej w rzekomej „Konstytucji Baranowskiego z 1696 r." s. 21-32; Krahel Tadeusz: Seminarium Duchowne w Białymstoku (1820-1843) s. 33-37; Rutkowski Marek: Funkcjonowanie szkół publicznych i prywatnych w Królestwie Polskim po powstaniu listopadowym s. 39-57; Miodowski Adam: Stopień alfabetyzacji społeczności powiatu białostockiego u schyłku XIX wieku 
na tle lokalnych uwarunkowań rosyjskiej polityki oświatowej s. 69-84; Kozyrska Antonina: Kwestia języka nauczania religii w szkołach rzymsko-katolickiej diecezji wileńskiej na początku XX wieku s. 85-100; Szpoper Dariusz, Dąbrowski Przemysław: Idea utworzenia wyższego zakładu naukowego w Wilnie na początku XX wieku s. 101-118; Białokur Marek: Działalność oświatowo-wychowawcza polskiego środowiska w Wilnie u progu XX stulecia w świetle wspomnień s. 119-129; Snopko Jan: Między edukacją a polityką. O polskie szkolnictwo w Wilnie podczas okupacji niemieckiej w latach 1915-1918 s. 131-138; Januszewska-Jurkiewicz Joanna: Uczniowie wyznania mojżeszowego w szkołach wileńskich w okresie Litwy Środkowej s. 139-149; Śleszyński Wojciech: Wychować lojalnych obywateli. Polityka oświatowa władz polskich na ziemiach północno-wschodnich II Rzeczypospolitej (1919-1939) s. 151-158; Kubis Barbara: Wpływ wychowania rodzinnego na kształtowanie się świadomości narodowej na Kresach Północno-Wschodnich w okresie II Rzeczypospolitej s. 159-171; Smolarczyk A.: Powszechność nauczania w województwie poleskim w latach 1919-1939 s. 173-192; Pačkovǐc Alena: Udzel pol'skìh gramadskih arganìzacyj u vyhavannì ì asvece nasel'ìctva Zahodnâj Belarusì (1921-1939 gg.) s. 201-209; Jekabsons Ëriks: Polskie, białoruskie i litewskie szkolnictwo na Łotwie W okresie międzywojennym s. 211-220; Ladyseŭ Uladzìmìr: Prablema étnakul'turnaj samaìdèntyfikacyì belarusaŭ u mižvaennaj Pol’ščy s. 221-225; Švajko Valentina: Russkaâ pressa i biblioteki v Zapadnoj Belarusi v 1920-30-e gg. s. 227-234; Zackiewicz Grzegorz: Seweryn Wysłouch o problemie kształtowania się białoruskiej świadomości narodowej na ziemiach północno-wschodnich II Rzeczypospolitej s. 235-242; Stobniak-Smogorzewska Janina: Wychowanie młodzieży i działalność oświatowa kresowego osadnictwa wojskowego 1920-1940 s. 255-257; Harrčenko Oksana: Reformirovanie sistemy škol'nogo obrazovaniâ v Zapadnoj Belarusi. Sentâbr' 1939 - iûn' 1941 gg. s. 259-266; Autuchiewicz Jerzy: Sowiecki system oświatowy wobec deportowanych dzieci polskich w latach 1940-1946 s. 267-275; Sychowicz Krzysztof: Działalność aparatu bezpieczeństwa wobec środowiska oświatowego w woj. białostockim w latach 1945-1949 s. 277-287; Magier Dariusz: Jaką świadomość kształtowała oświata Polski stalinowskiej? Ustrój szkolnictwa w pierwszych latach Polski Ludowej s. 289-299; Szumski Jan: Szkolnictwo polskojęzyczne w zachodnich obwodach BSRS w latach 1944-1948 s. 301-309; Pogorzelski Krzysztof: Problem analfabetyzmu i próby jego likwidacji przez władzę ludową na Białostocczyźnie w latach 1944-1952 s. 311-325; Iwaniuk Sławomir: Szkolnictwo białoruskie w świetle akt Prezydium Powiatowej Rady Narodowej i Urzędu Powiatowego w Hajnówce z lat [1946-1953] 1954-1975 s. 327-337; Jarmusik Edmund: Rola Kościoła i rodziny w religijnym wychowaniu dzieci i młodzieży na Białorusi s. 339-346; Matelski Dariusz: Rola oświaty i szkolnictwa w procesie kształtowania się świadomości narodowej Niemców na pograniczu polsko-litewsko-białoruskim s. 347-376; Nieciecki Jan: „Avant-cour” białostockiej rezydencji s. 379-384.

51. ROMANIUK Zbigniew: Szkolnictwo w Brańsku na przestrzeni dziejów. Brańsk-Białystok 2007 Libra ss. 183, nlb. 36, tabl. 24, il.

52. SEPIOŁ Andrzej Stanisław: Rozwój szkolnictwa na terenie Harklowej do końca XIX wieku. Rocz. Jas. T. 6: 2006 s. 73-96.

Od XVI w.

53. SIEDEM wieków szkolnictwa w Rawie Mazowieckiej. Pod red. Eugeniusza Walczuka. Łódź 2007 Papier-Service Wojciech Grochowalski ss. 432, il.

Treść: Walczuk E.: Słowo wstępne s. 5-6; Szymczakowa Alicja: Początki szkolnictwa (XIV-XVI w.) s. 9-27; Wojtyska Henryk Damian: Kolegium jezuickie - pierwsza szkoła średnia w Rawie (1620-1773) s. 29-60; Puś Wiesław: Szkolnictwo w Rawie i powiecie rawskim w okresie zaborów (1793-1914) s. 61-69; Massalski Adam: Szkoła obwodowo-powiatowa w Rawie (1835-1862) s. 71-95; Mirek Agata: Odbudowa i rozwój szkolnictwa powszechnego w Rawie i powiecie rawskim po odzyskaniu niepodległości (1918-1939) s. 97-118; Grochowolski Wojciech: Szkolnictwo średnie w Rawie Mazowieckiej w okresie międzywojennym (1918-1939) s. 119-134; Góral Jan: Szkolnictwo jawne i tajne w powiecie rawskim w latach okupacji hitlerowskiej (1939-1945) s. 135-167; Walczuk E.: Zarys powstania i rozwoju szkolnictwa zawodowego w Rawie Mazowieckiej s. 169-222; Zakrzewski Bogusław: Wkład polskich pedagogów z Galicji, Kresów i Rosji w oświatę na ziemi rawskiej s. 223-262; Błądek Witold: Stefania Zakrzewska s. 263-265; Wspomnienia o szkole i nauczycielach, czasach przemocy i nadziei s. 269-337; Zakrzewski B.: Biogramy wybranych nauczycieli i społeczników s. 339-356; Walczuk E.: Maturzyści z lat 1945-1955 s. 357-368; Stowarzyszenie Wychowanków Gimnazjum i Liceum Ogólnokształcącego im. Marii Skłodowskiej-Curie s. 369-394. 
54. STARNAWSKI Jerzy: Uniwersytet świątynią wiedzy. Łódź 2007 Woj. i MBP im. Marszałka Józef Piłsudskiego ss. 90, nlb. 1, tabl. 1.

XIV-XX w.; Publ. wyd. z okazji 85. rocznicy urodzin prof. Jerzego Starnawskiego.

55. [STO] 100 lat salezjanów w Przemyślu. [Red.] Jerzy Gocko, Kazimierz Skałka. Przemyśl-Kraków 2007 Poligrafia Inspektoratu Tow. Salezjańskiego ss. 193, nlb. 4, tabl. 32, il.

Z treści: Żurek Waldemar W.: Inicjatywy wychowawcze i dydaktyczne salezjanów w Przemyślu 1907-2007 s. 87-126; Kulpaczyński Stanisław: System prewencyjny w działalności pedagogiczno-wychowawczej salezjanów w Przemyślu 1907-2007 s. 129-140.

56. TOMASZEWSKI Roman: W Polsce i na obczyźnie 1939-1956. Zarys dziejów szkolnictwa wojskowego. Torun 2006 Adam Marszałek ss. 279, il., rès., rez., sum., Zsfg.

57. TRADYCJE nauki legnickiej. Konferencja naukowa z okazji 480 rocznicy założenia uniwersytetu w Legnicy, 12 października 2006 r. Red. nauk. Stanisław Dąbrowski. Legnica 2007 Państ. Wyższa Szkoła Zawodowa im. Witelona w Legnicy ss. 142.

Rec.: Laszewski Witold, Szkice Legnickie. T. 28: 2007 s. 335-336.

58. TRZCIANA. Zarys dziejów wsi. Zespół red. Zofia Dziedzic, Zbigniew Lis, Janusz Pisula. Trzciana 2007 Tow. Przyj. Trzciany; Urząd Gm. w Świlczy; Gm. Centrum Kultury w Świlczy z siedzibą w Trzcianie ss. 800 , tabl. 48 , il.

Z treści: Oświata i szkolnictwo: Dziedzic Z.: Wychowanie przedszkolne s. 399-406; Dziedzic Z.: Szkolnictwo podstawowe s. 407-467; Kalendarium ZS [Zespołu Szkół] w Trzcianie s. 467-470; Uzupełnienia: Stawarz Adam: Wspomnienia z okresu rozbudowy szkoły s. 471-475; Irzyński Jan: Harcerskie tradycje s. 475480; Dziedzic Z.: Szkolnictwo artystyczne w Trzcianie (1993-2007) s. 481-490; Dziedzic Z.: Szkoła w Trzcianie-Słotwince (1914-1998) s. 491-502; Dziedzic S.: Znak czasów i tożsamości. Szkoła „u Christianach” s. 503-527; Szumilas Marian: Pracownicy Zespołu Szkół w latach 1945-2006 s. 528-536.

59. W SŁUŻBIE nauki, kultury i edukacji. Księga pamiątkowa dedykowana prof. Lechowi Mokrzeckiemu z okazji jubileuszu pięćdziesięciolecia pracy zawodowej. Pod red. Romualda Grzybowskiego i Tomasza Maliszewskiego. Gdańsk 2006 Wydaw. Uniw. Gdańskiego ss. 488, il.

60. WALCZAK Aleksander: 85 lat polskiego szkolnictwa morskiego. Nautologia. R. 40: 2005 s. $72-76$.

Lata $1920-2005$.

61. WAWER i jego osiedla. Pod red. Jana Czerniawskiego; przy współpr. Mirosławy Skoczeń. Warszawa 2007 Wydz. Kultury dla Dzielnicy Wawer m. st. Warszawy ss. 465, tabl. LX, il. (Biblioteka Wawerska; 3).

Z treści: Frącek Teresa Antonietta: Siostry Franciszkanki Rodziny Maryi w służbie dzieciom s. 191-228; Bojanowicz Teresa: Placówki oświatowe s. 341-386.

62. WIDELAK Dariusz: Z dziejów szkolnictwa na Ziemi Strzeleckiej w XX i XXI wieku. Opole 2007 Wydaw. UO ss. 188, tabl. 4, il. Uniw. Opolski. (Studia i Monografie; nr 383).

63. WILCZYŃSKI Zenon: Oświata na terenie gminy Wąbrzeźno w okresie międzywojennym i w czasie drugiej wojny światowej. W: Historia gminy Wąbrzeźno. Pod red. Romana Czai. Wąbrzeźno 2006 s. 243-275.

64. Z DZIEJÓW oświaty na ziemiach polskich w XIX i XX wieku. Studia i szkice. From history of education on Polish lands in 19th and 20th centuries. Studies and drafts. Pod red. Marzeny Pękowskiej. Kielce 2007 Wszechnica Świętokrzyska. Wydaw. Uczelniane ss. 378, il., sum. (Prace Wszechnicy Świętokrzyskiej; nr 109).

Treść: Pękowska M.: Wstęp s. 9-11; Massalski Adam: Nauczyciele języka polskiego szkół średnich męskich rządowych w Królestwie Polskim w latach 1833-1862 s. 15-77; Kula Ewa: Nauczyciele religii rzymsko- 
katolickiej w rządowych męskich szkołach średnich Królestwa Polskiego w latach 1862-1873 s. 79-104; Rędziński Kazimierz: Z dziejów szkolnictwa żydowskiego w Będzinie w latach 1871-1914 s. 105-134; Stawiak-Ososińska Małgorzata: Poglądy pedagogiczne Narcyzy Żmichowskiej (w świetle „Pogadanek pedagogicznych” i „Listów” s. 135-156; Meissner Andrzej: Sprawozdania instytucji szkolnych, organizacji i towarzystw kulturalno-oświatowych jako źródło do dziejów oświaty w Galicji s. 159-168; Ogliczenko Lilia: Źródła do dziejów ruchu studenckiego w Centralnym Państwowym Archiwum Historycznym Ukrainy we Lwowie s. 169-181; Rusiecki Mieczysław: Katecheci szkół elementarnych w Galicji na przełomie XIX/XX wieku s. 183-214; Haratyk Anna: Wychowanie patriotyczne i obywatelskie na galicyjskich koloniach wakacyjnych s. 215-225; Krasińska Izabela, Stawiak-Ososińska M.: Towarzystwo Szkoły Ludowej i jego działalność na rzecz abstynencji w Galicji w latach 1904-1914 s. 227-239; Łapot Mirosław: Powstanie pierwszych żydowskich zakładów dla sierot w Galicji s. 241-261; Majewski Stanisław: Organizacja i potrzeby szkolnictwa II Rzeczypospolitej w okresie pokryzysowym 1936-1939 s. 265-302; Walasek Stefania: Towarzystwa i organizacje oświatowe na ziemiach północno-wschodnich ze szczególnym uwzględnieniem Wilna s. 303-312; Pękowska M.: Wprowadzenie do badań nad żydowskimi stowarzyszeniami i zakładami dla głuchych i niewidomych w II RP s. 313-321; Łozowska Kamilla: Edukacja seksualna w dwudziestoleciu międzywojennym s. 323-335; Nowak-Starz Grażyna, Zdziebło Kazimiera: Ewolucja wybranych systemów szkolnictwa pielęgniarskiego na przełomie XIX i XX wieku s. 337-350; Krasuski Józef: Jawne i tajne szkolnictwo polskie pod okupacją niemiecką, sowiecką i litewską w okresie II wojny światowej s. 353-364; Adamczyk Mieczysław: Szkolnictwo i oświata na łamach konspiracyjnej prasy ludowej drugiej wojny światowej s. 365-375.

65. Z TRADYCJI historii kultury i oświaty. Studia ofiarowane Jerzemu Kukulskiemu w siedemdziesiątą rocznicę urodzin i czterdziestą rocznicę pracy naukowej. Pod red. Michała Pindery. Piotrków Trybunalski 2007 Nauk. Wydaw. Piotrkowskie przy Filii Akad. Świętokrzyskiej ss. 699, nlb. 5. Akad. Świętokrzyska im. Jana Kochanowskiego w Kielcach. Filia w Piotrkowie Trybunalskim.

Z treści: Pindera M.: Jerzy Kukulski - życie i działalność naukowo-dydaktyczna s. 11-15; Pindera Agata P.: Bibliografia prac profesora Jerzego Kukulskiego w latach 1967-2006 s. 17-21; Bartczak Zenon: Piotrkowskie gimnazjum rządowe w okresie międzypowstaniowym s. 35-50; Chmielewski Witold, Kowalski Seweryn: Zygmunt Kowalski (1914-1985) - pracowite życie pedagoga s. 89-121; Frycie Stanisław: Przekłady obcej prozy - powieści oraz opowiadań historycznych i biograficznych dla dzieci i młodzieży z lat 1970-1989 s. 155-169; Goriszowski Włodzimierz: Literatura historyczna oraz społeczno-polityczna, jej czytelnictwo w procesie patriotycznego wychowania młodych czytelników s. 187-198; Jaworski Rafał: Relacja Ambrogio Contarniego jako źródło do edukacji synów Kazimierza Jagiellończyka s. 199-208; Kowolik Piotr: Myśl filozoficzno-pedagogiczna w zniewolonej Polsce s. 227-244; Lech Andrzej: Istota i cele aktywności kulturalnej młodzieży chłopskiej w okresie II Rzeczypospolitej s. 245-254; Massalski Adam: Nauczyciele przedmiotów matematyczno-przyrodniczych szkół średnich w Królestwie Polskim w latach 1833-1862 s. 279-327; Motylski Jan Andrzej: Organizacja szkolnictwa powszechnego w Piotrkowie Trybunalskim w latach 1918-1939 s. 347-367; Olszewska Małgorzata: Kwalifikacje zawodowe i procedury zatrudniania nauczycieli publicznych szkół powszechnych w latach 20. XX wieku ze szczególnym uwzględnieniem województwa wołyńskiego s. 403-415; Pindera M.: Poglądy myślicieli o nauczycielu w Polsce w XIX stuleciu s. 477-497; Wołoszyński Ryszard W.: Doskonalenie nauczycieli historii w Piotrkowie Trybunalskim 1974-1981 s. 679-687.

\section{Okres do 1795 roku}

66. BUDZYŃSKI Józef: Czy na dawnym Śląsku był antysemityzm? Przyczynki szkolne do historii Żydów w XVII i XVIII w. Rocz. Łubowicki. T. 1: 2003 s. 96-115, Zsfg., shrnutí.

67. BUDZYŃSKI J.: Dawna szkoła humanistyczna w kręgu języka i literatury. Pr. Nauk. Akad. im. J. Dtugosza. Filologia Pol. Historia i teoria literatury. [T.] 10: 2006 s. 5-12.

XVI w. 
68. BUDZYŃSKI J.: Dialog szkolny w procesie formowania człowieczeństwa w dawnych gimnazjach humanistycznych (XVI-XVIII w.). Pr. Nauk. Akad. im. J. Dtugosza. Filologia Pol. Historia i teoria literatury. [T.] 10: 2006 s. 13-20.

69. CHORĄŻYCZEWSKI Waldemar, Roszak Stanisław: Bunt w konwikcie. Karta z dziejów oświaty w czasach saskich. W: Między Lwowem a Wrocławiem. Księga jubileuszowa profesora Krystyna Matwijowskiego. Pod red. Bogdana Roka i Jerzego Maronia. Torun 2006 s. 631-640.

70. DĘBOWSKA Maria: Kształcenie dziewcząt w klasztorze norbertanek w Imbramowicach w XVIII wieku. W: Historia świadectwem czasów. Księdzu profesorowi Markowi Tomaszowi Zahajkiewiczowi. Red. Włodzimierz Bielak, Stanisław Tylus. Lublin 2006 s. 177-192.

71. GERLIC Henryk: Udział cystersów rudzkich w kształceniu kadry nauczycielskiej na Śląsku w XVIII wieku. W: Klasztor w państwie średniowiecznym i nowożytnym. Red. Marek Derwich, Anna Pobóg-Lenartowicz. Warszawa-Wrocław-Opole 2005 s. 405-426.

72. HOSZOWSKA Mariola: Arianie i problem polskiej tolerancji religijnej w podręcznikach historii późnego Oświecenia. W: Wielokulturowe środowisko historyczne Lwowa w XIX i XX w. T. 5. Pod red. Jerzego Maternickiego, Leonida Zaszkilniaka. Rzeszów 2007 s. 107-129.

73. HOSZOWSKA M.: Obraz kobiet w XVIII-wiecznych podręcznikach historii ojczystej na przykładzie opracowania Fryderyka Augusta Schmidta. Kresy Poludn.-Wsch. R. 1: 2003 nr 1 s. $67-78$.

74. KACZMAREK Krzysztof: Król Władysław Jagiełło wobec krakowskich szkół cystersów i dominikanów. W: Klasztor w państwie średniowiecznym i nowożytnym. Red. Marek Derwich, Anna Pobóg-Lenartowicz. Warszawa-Wrocław-Opole 2005 s. 341-350.

75. KACZMAREK K.: Związki norbertanów z Uniwersytetem Krakowskim na tle innych zakonów w okresie średniowiecza. W: Premonstratensi na ziemiach polskich w średniowieczu i epoce nowożytnej. Pod red. Jerzego Rajmana. Annales APC. Folia 40: Studia Historica. [T.] 5: 2007 s. $159-170$.

76. KARDAŚ Artur: Edukacja i wychowanie młodzieży miejskiej w Rzeczypospolitej okresu baroku. Wybrane zagadnienia. W: Cnoty i wady. Społeczeństwo baroku po obu stronach Karpat. Pod red. J[ózefa] Mareckiego i L[ucyny] Rotter. Kraków 2007 s. 183-195.

77. KOLEGIA uniwersyteckie średniowiecznej Europy. Katalog wystawy Muzeum Uniwersytetu Jagiellońskiego. University colleges of medieval Europe. Catalogue of the exhibition Jagiellonian University Museum. Koncepcja i red. merytoryczna Maria Natalia Gajek. Kraków 2007 Muzeum UJ ss. 357, nlb. 2, il.

Treść: Waltoś Stanisław: Wprowadzenie s. 7-13; Pietrzyk Zdzisław, Tatarzyński Ryszard: Kolegia w ustroju uniwersyteckim s. 17-29; Węcławowicz Tomasz: Średniowieczne kolegia uniwersyteckie i ich rekonstrukcje s. 31-46; Dybiec Julian: Nauczanie w średniowiecznych uniwersytetach s. 47-68; Markowski Mieczysław: Uprawianie nauki w średniowiecznych uniwersytetach s. 69-96; Stopka Krzysztof: Życie codzienne w kolegiach uniwersyteckich średniowiecza s. 97-124; Katalog s. 125-357.

78. KRUKOWSKI Jan: Nauczyciele szkół parafialnych Krakowa w XVI wieku. Kraków 2007 Wydaw. Nauk. Akad. Pedag. ss. 190, nlb. 2, tabl. 10, il. Akad. Pedag. im. Kom. Edukacji Nar. w Krakowie. (Prace Monograficzne; nr 463).

79. KRYŃSKA Elwira J.: Staropolski etos wychowania. Białystok 2006 Trans Human ss. 157.

Rec.: Skreczko Adam, Prz. Hist.-Ośw. R. 50: 2007 nr 3 s. 205-206. 
80. LEWANDOWSKA-MALEC Izabela: Spór akademików z jezuitami o monopol na szkolnictwo wyższe w Koronie. Zagadnienia historycznoprawne. W: Cuius regio, eius religio? II. Publikacja po Zjeździe Historyków Państwa i Prawa, Lublin, [20-23] wrzesień 2006 r. Red. Grzegorz Górski, Leszek Ćwikła, Marzena Lipska. Lublin 2006 s. 85-96.

81. MAGRYŚ Roman: Kształt historiograficzny „Stanu oświecenia w Polsce” Hugona Kołłątaja. Pr. Hum. [Rzeszów]. Ser. 1. Nr 32: 2006 [z.] 7 s. 76-90, streszcz.

82. MIESZEK Małgorzata: Kilka uwag o intermediach z lwowskiego kolegium księży teatynów. Acta UL. Folia Litteraria Polonica. [Vol.] 9: 2007 s. 53-61.

Teatr szkolny, XVII w.

83. MYSZOR Jerzy: Ślązacy na uniwersytetach średniowiecznych. W: Słowianie, Górnoślązacy, Rudzianie. Red. Andrzej Złoty. Katowice 2007 s. 29-40.

84. PELCZAR Roman: Szkoła kolegiacka i jej rola w życiu kulturalnym Jarosławia w XVI-XVIII wieku. Prz. Hist.-Ośw. R. 50: 2007 nr 1/2 s. 5-19.

85. PELCZAR R.: Teatr Collegium Nobilium teatynów w Warszawie w XVIII wieku i jego rola kulturotwórcza. Pam. Teatr. R. 55: 2007 z. 1/2 s. 41-52.

86. PIETRZYK Zdzisław, Tatarzyński Ryszard: Idea uniwersytetu: królowa Jadwiga i Stanisław ze Skarbimierza. W: Święta Jadwiga Królowa [1374-1399]. Abyśmy byli godni tego dziedzictwa. Red. Helena Byrska, Antoni Bednarz. Kraków 2006 s. 29-47.

87. PUCHOWSKI Kazimierz: Jezuickie kolegia szlacheckie Rzeczypospolitej Obojga Narodów. Studium z dziejów edukacji elit. Gdańsk 2007 Wydaw. Uniw. Gdańskiego ss. 636, il., sum.

XVII-XVIII w.

88. RÓŻAŃSKI Mieczysław: Ideał wychowawczy szkół parafialnych. W: Cnoty i wady. Społeczeństwo baroku po obu stronach Karpat. Pod red. J[ózefa] Mareckiego i L[ucyny] Rotter. Kraków 2007 s. 173-182.

89. RULES for behavior of Jewish teachers in the schools of Galicia and Ludomeria. Ed. by Rachel Manekin. Gal-Ed. Vol. 20: 2006 s. 113-124, sum. s. 138-139.

Z 1. 1780-1787.; w jęz. hebr.

90. STASIAK Arkadiusz M.: Kongres badaczy osiemnastego wieku. „Wiek XVIII: Polityka Kultura - Edukacja" (Wrocław 19-21 X 2006). Rocz. Hum. T. 55: 2007 z. 2 s. 265-266.

91. ŚWIDERSKA-WŁODARCZYK Urszula: Ambicje edukacyjne szlachty polskiej na przełomie średniowiecza i czasów nowożytnych. W: Opuscula archaeologica. Opera dedicata in professorem Thaddeum Malinowski. Red. nauk. Wojciech Dzieduszycki. Zielona Góra 2007 s. 339-351.

92. WALCZAK Wojciech: O wykształceniu duchowieństwa unickiego w Rzeczypospolitej w XVII-XVIII wieku. W: Nad społeczeństwem staropolskim. T. 1: Kultura, instytucje, gospodarka w XVI-XVIII stuleciu. Pod red. Karola Łopateckiego i Wojciecha Walczaka. Białystok 2007 s. $483-491$.

93. WIERZBICKI Piotr: Szlachta w kolegium oo. Pijarów w Podolińcu (1699-1711). Zesz. Sadec.-Spiskie. T. 2: 2007 s. 38-70, streszcz. słowackie. 
94. WIJACZKA Jacek: Podróż śląskiego szlachcica na studia do Królewca w 1719 roku. W: Etniczne, kulturowe i religijne pogranicza Rzeczypospolitej w XVI-XVIII wieku. Pod red. Krzysztofa Mikulskiego i Agnieszki Zielińskiej-Nowickiej. Toruń 2005 s. 278-287.

95. WOLAŃSKI Filip: Młodość i edukacja polskich bohaterów narodowych w świetle osiemnastowiecznych biografii. W: Etniczne, kulturowe i religijne pogranicza Rzeczypospolitej w XVI-XVIII wieku. Pod red. Krzysztofa Mikulskiego i Agnieszki Zielińskiej-Nowickiej. Toruń 2005 s. 311-316.

96. WRÓBEL-LIPOWA Krystyna: Dziecko w polskiej rodzinie ziemiańskiej w XVIII wieku. Res Historica. T. 23: 2006 s. 49-57.

\section{Okres 1795-1918}

97. BARNAŚ-BARAN Ewa: Sprawozdanie z międzynarodowej konferencji naukowej pt. „System oświaty w Galicji 1772-1918 i jego rola w przemianach cywilizacyjnych”. Biul. Hist. Wychowania. 2005/2006 [nr] 1/2 [dr.:] 2007 s. 248-249.

Kraków, 29-31 V 2006 r.

98. BEDNARZAK-LIBERA Mirosław: Działalność towarzystw oświatowych wśród chłopów w Europie Środkowej do 1914 r. W: Dzieje partii i stronnictw chłopskich w Europie. T. 1: Narodziny i rozwój. Kom. red. Józef Ryszard Szaflik [i in.]. Pułtusk-Warszawa 2007 s. 331-357.

99. BEREŚ Ewa: Z działalności Towarzystwa Szkoły Ludowej w Krośnie w latach 1901-1914. W: Szkice z dziejów Polski południowo-wschodniej i Europy XIX i XX wieku. Prace uczniów ofiarowane w sześćdziesiątą piątą rocznicę urodzin profesora Mariana Stolarczyka. Pod red. Andrzeja Bonusiaka, Edyty Czop, Jerzego Kuzickiego. Przemyśl 2005 s. 108-117.

100. BŁASZCZYK Grzegorz: Pierwsi Polacy na Uniwersytecie Dorpackim w latach 1802-1832. Kw. Hist. Nauki i Techn. R. 52: 2007 nr 3/4 s. 185-223.

101. BRZEZIŃSKA Jadwiga: Instytut profesorski w Tartu (1828-1838) i jego rola w kształceniu kadry naukowej dla carskiej Rosji. W: Medycyna i farmacja XIX i XX wieku. Zagadnienia wybrane. Pokłosie Jubileuszowego Naukowego XX Krajowego Zjazdu Polskiego Towarzystwa Historii Medycyny i Farmacji. Pod red. Romana Meissnera. Poznań 2007 s. 43-51.

102. BUDNY Rafał: Stowarzyszenie Katolickich Nauczycieli Wielkiego Księstwa Poznańskiego w „Kartkach mojego życia” Piotra Palińskiego (1892-1896). W: Z dziejów pogranicza kujawsko-wielkopolskiego. Zbiór studiów. Pod red. Dariusza Karczewskiego. Strzelno 2007 s. 125-134.

103. BUJAKOWSKI Maciej: Polska Macierz Szkolna w Bielsku-Białej. W: Dzieje partii i stronnictw chłopskich w Europie. T. 1: Narodziny i rozwój. Kom. red. Józef Ryszard Szaflik [i in.]. Pułtusk-Warszawa 2007 s. 359-368.

104. DĘBSKI Andrzej: Protesty pedagogów wobec kina i ruch reformy kinowej we Wrocławiu przed I wojną światową. Śl. Kw. Hist. Sobótka. R. 62: 2007 nr 4 s. 453-460.

105. ENGELGARD Jan: Narodowa Demokracja wobec bojkotu szkoły rosyjskiej 1905-1911. Niepodl. i Pam. R. 14: 2007 nr 2 s. 93-103.

W aneksie: Uchwała Zjazdu Stronnictwa Demokratyczno-Narodowego 2 czerwca 1911 roku w sprawie bojkotu szkoły rosyjskiej. 
106. FITA Stanisław: Lubelscy wychowankowie Szkoły Głównej Warszawskiej - ich rola w kulturze miasta i regionu. W: Hieronim Łopaciński. Epoka, ludzie, region. Materiały z konferencji naukowej, Lublin, 19-20 września 2006 r. Pod red. Zdzisława Bielenia. Lublin 2006 s. 165-174.

107. GIEŁDOŃ-PASZEK Aleksandra: Zarys teorii i praktyki dydaktycznej w zakresie malarstwa pejzażowego na akademiach sztuk pięknych w Europie i w Polsce od momentu powstania akademii do początków XX wieku. Cieszyn 2006 Uniw. Śląski w Katowicach. Inst. Sztuki. Wydz. Artystyczny ss. 136, nlb. 1.

108. GŁOWACKA-SOBIECH Edyta: Wychowanie ku „najwyższym” wartościom w działalności i programie „Eleusis” w okresie niewoli narodowej. Biul. Hist. Wychowania. 2005/2006 [dr.:] 2007 [nr] 1/2 s. 51-57.

109. GRABOWSKI Piotr: Rola polskiej kartografii wobec zaostrzenia ustawodawstwa w zaborze pruskim na przełomie XIX i XX wieku. Masovia. T. 10: 2007 s. 3-11.

Wpływ na wychowanie patriotyczne.

110. HAŁABUDA Marek: Krakowskie Seminarium Duchowne (1801-1901). Kraków 2007 WN PAT ss. 381. PAT w Krakowie. Wydz. Hist. Kościoła. (Rozprawy Doktorskie).

111. HAPTAŚ Krzysztof: Uczniowie z Mielca i regionu w III Gimnazjum im. Franciszka Józefa I we Lwowie w latach 1858-1908. Przyczynek do dziejów kształcenia gimnazjalnego młodzieży z powiatu mieleckiego. Rocz. Miel. T. 9: 2006 [dr.:] 2007 s. 155-159.

112. HARATYK Anna: Udział społeczeństwa galicyjskiego w opiece nad dziećmi ubogimi i osieroconymi (1867-1914). Kraków 2007 Impuls ss. 340, nlb. 4, il.

113. HARTMANN Stefan: Zakłady penitencjarne i poprawcze w Grudziądzu w latach 1831-1876. Rocz. Grudz. T. 17: 2007 s. 77-92.

114. HOMOLA-SKĄPSKA Irena: Z dziejów Krakowa, Galicji i Śląska Cieszyńskiego. Wybór pism historycznych. Wyboru dokonał, oprac. i wstępem poprzedził Grzegorz Nieć. Kraków-Warszawa 2007 Księg. Akademicka; IH PAN ss. 596, nlb. 4, tabl. 4, il. (Regiony, Historia, Kultura; nr 2).

Z treści: Nauczycielstwo krakowskie w okresie autonomii (1867-1914) s. 107-150; Prasa galicyjska wobec sprawy gimnazjum polskiego w Cieszynie (1895-1903) s. 495-514.

115. HOSZOWSKA Mariola: Miłość małżeńska i pozamałżeńska w podręcznikach historii ojczystej 1795-1830. Kresy Połudn.-Wsch. R. 2: 2004 nr 1 s. 85-96.

116. JOKIEL Irena: Romantyk je obiad i wychowuje dzieci. W: Codzienność w literaturze XIX (i XX) wieku. Od Adalberta Stiftera do współczesności. Pod red. Grażyny Borkowskiej i Anety Mazur. Opole 2007 s. 213-226.

117. JUŚKO Edmund: Szkolnictwo ludowe w Tarnowie i powiecie tarnowskim pod koniec XIX i na początku XX wieku. W: Tarnów w czasach burmistrza Tadeusza Tertila. Osiągnięcia miasta w okresie autonomii galicyjskiej i początkach II Rzeczypospolitej. Pod red. Pawła Juśko. Tarnów 2007 s. 145-173.

118. KOŁODZIEJCZYK Arkadiusz: Przemiany w oświacie i kulturze wsi Królestwa Polskiego w dobie rewolucji 1905 roku. W: Dziedzictwo rewolucji 1905-1907. Pod red. nauk. Anny Żarnowskiej [i in.]. Radom-Warszawa 2007 s. 227-243.

119. KOPRUKOWNIAK Albin: Aktywność oświatowo-kulturalna i społeczna ziemianek w regionie lubelskim na przełomie XIX i XX wieku. W: Hieronim Łopaciński. Epoka, ludzie, re- 
gion. Materiały z konferencji naukowej, Lublin, 19-20 września 2006 r. Pod red. Zdzisława Bielenia. Lublin 2006 s. 143-152.

120. KUDŁA Lucyna: Pozaszkolne życie gimnazjalistów krakowskich doby autonomicznej (1867-1918). W: Kraków. Studia z dziejów miasta. W 750 rocznicę lokacji. Pod red. nauk. Jerzego Rajmana. Kraków 2007 s. 186-198.

121. KUR Elżbieta M.: Nauczanie historii literatury polskiej w Królestwie Polskim. (1864-1905). Siedlce 2007 Wydaw. AP ss. 164. Akad. Podlaska. (Monografie; nr 77).

122. KWAK Jan: Zakład dla Sierot im. św. Heleny we Lwowie od końca XIX do początków XX wieku. Przyczynek do dziejów opieki społecznej. Rocz. Przem. R. 43: 2007 z. 4 s. 157-161.

123. LINDMAJER Józef: Szkoła miejska w Sławnie od końca XVIII wieku do 1914 roku. Cz. 2. Zesz. Stawień. [Z.] 2: 2004 s. 5-18.

Cz. 1. Dorzecze. Nr 11/12: 2001/2002 s. 5-13.

124. MAJ Sławomir: Rola podręczników i poradników rolniczych w upowszechnianiu postępu agrotechnicznego w XIX wieku. Studia Hist. R. 50: 2007 z. 3/4 s. 319-331, sum.

125. MASSALSKI Adam: Nauczyciele religii w szkołach średnich rządowych w diecezji krakowsko-kieleckiej i sandomierskiej w okresie międzypowstaniowym (1833-1862). Kiel. Studia Teol. T. 3: 2004 s. 381-399, sum.

126. MATEJUKOWA Maria Irena: Formy tajnej działalności oświatowej w Warszawie na przełomie XIX i XX w. w obronie przed rusyfikacją. Kronika Warszawy. 2003 nr 1/2 s. 29-54.

127. MĘDELSKA Jolanta: „Nauczyciel Adam Mickiewicz poprawiał i zdanie zapisywał”. Jęz. Pol. R. 87: 2007 z. 2 s. 120-134.

Mickiewicz jako nauczyciel języka polskiego i jego ówczesne słownictwo.

128. MOKLAK Jarosław: Szkoła i polityka. Na drodze do gimnazjum ukraińskiego w Kołomyi, 1892. W: Polska Ukraina. Osadczuk. Księga jubileuszowa ofiarowana profesorowi Bohdanowi Osadczukowi w 85. rocznicę urodzin. Pod red. Bogumiły Berdychowskiej i Oli Hnatiuk. Lublin 2007 s. 38-46.

129. NADOLSKI Waldemar: Wychowanie fizyczne i sport na Ziemi Sądeckiej w latach 1867 -1918. Nowy Sącz 2007 Waldemar Nadolski ss. 215, nlb. 1, il.

130. NAWROT-BOROWSKA Monika: Bony w wychowaniu domowym dzieci polskich w latach 1850-1914. Biul. Hist. Wychowania. 2005/2006 [dr.:] 2007 [nr] 1/2 s. 25-50.

131. NIEWĘGŁOWSKA Aneta: Średnie szkolnictwo żeńskie w Prusach Zachodnich w latach 1807-1911. Zapiski Hist. T. 72: 2007 z. 2/3 s. 89-110, Zsfg., sum.

132. NIKLEWSKA Jolanta: Polskie szkoły prywatne w Królestwie Polskim w latach 1905-1915 jako teren nauczania i wychowania. W: Dziedzictwo rewolucji 1905-1907. Pod red. nauk. Anny Żarnowskiej [i in.]. Radom-Warszawa 2007 s. 217-226.

133. NOWACKI Tadeusz W.: Zwycięska walka młodzieży o szkołę polską 1901-1917. Niepodl. i Pam. R. 14: 2007 nr 2 s. 37-91.

134. NOWAK Mariusz: Problematyka treści patriotycznych w tzw. „wychowaniu domowym” młodzieży ziemiańskiej w Królestwie Polskim w latach 1864-1914. W: Polski obyczaj patriotyczny od XVIII do przełomu XX/XXI w. - ciągłość i zmiana. Pod red. nauk. Andrzeja Stawarza i Wiesława Jana Wysockiego. Warszawa 2007 s. 77-88. 
135. OLAK Sławomir: Drzewica w XIX wieku. Szkoła elementarna, parafia, miasto. Radom-Rusinów 2007 Sławomir Olak ss. 200, il.

136. OLENDER Elżbieta: Strajki szkolne w południowo-zachodniej Wielkopolsce. W: Walka o polskość w południowo-zachodniej Wielkopolsce w I połowie XX wieku. Wzory postaw patriotycznych. Wypisy tekstów źródłowych. Leszno 2006 s. 6-12.

137. PIĄTKOWSKI Sebastian: Ewangelicka szkoła elementarna w Radomiu (1842-1919). W: Ewangelicy w Radomiu i regionie (XVI-XX w.). Studia i materiały. Pod red. Jarosława Kłaczkowa. Radom 2007 s. 59-70.

138. POCZET filomatów chojnickich. W 150. rocznicę śmierci Adama Mickiewicza i Tomasza Zana. Pod red. Kazimierza Jaruszewskiego. Chojnice 2005 Hegard; Tow. Przyj. LO im. Filomatów Chojnickich ss. 108, il. (Biblioteka Filomaty; t. 1).

Z treści: Boczek Paweł, Kuffel Bogdan: Z dziejów szkoły s. 5-23; Jaruszewski K.: Filomaci wileńscy s. 24-26; Jaruszewski K.: Rys historyczny ruchu filomackiego w gimnazjum chojnickim s. 27-31; Jaruszewski K.: Dr Hipolit Ostoja-Lniski [1853-1931]. Opiekun filomackiej braci s. 32-36; Jaruszewski K.: Sylwetki filomatów chojnickich zasłużonych dla historii i kultury Pomorza s. 37-91; Jaruszewski K.: Z filomackiego księgozbioru s. 92-96; Spis alfabetyczny członków tajnych kół filomackich w Chojnicach w latach 1830-1920 s. 97-101.

139. PYSZKO Stanisław: Zarys dziejów oświaty na ziemi chełmskiej w latach 1815-1875. Rocz. Chetm. T. 10: 2006 s. 73-97.

140. RUCHAŁA Krzysztof: „Szkolnictwo Ludowe” („Szkolnictwo”) 1891-1913. Almanach Sądecki. R. 16: 2007 nr 1/2 s. 92-120.

Czasopismo wyd. w Nowym Sączu.

141. SADURSKI Ireneusz: Korpus nauczający Gimnazjum Wojewódzkiego (Gubernialnego) w Lublinie w latach 1832-1864. Rocz. Nauk Spot. T. 35: 2007 z. 2 s. 143-166, sum.

142. SAWRYCKI Władysław: Kultura antyczna w szkolnej edukacji romantyków. W: Filhellenizm w Polsce. Rekonesans. Praca zbiorowa. Pod red. Małgorzaty Borowskiej [i in.]. Warszawa 2007 s. $182-201$.

143. SECH Jacek: Szkolnictwo polskie w Strzelnie w czasach zaboru pruskiego 1815-1918. W stulecie strajku szkolnego. W: Z dziejów pogranicza kujawsko-wielkopolskiego. Zbiór studiów. Pod red. Dariusza Karczewskiego. Strzelno 2007 s. 135-143.

144. STALIUNAS Darius: Kto powinien uczyć „innowierców”? Problem nauczycieli i szkół elementarnych dla Żydów w imperialnej polityce Rosji w połowie XIX wieku. Biul. Hist. Pogranicza. Nr 8: 2007 s. 23-39, sum., santr., rez.

145. STANISZEWSKI Karol: Prasa polska Prus Zachodnich a akty prawne dotyczące szkolnictwa Prus Zachodnich w latach 1850-1866. Studia Gnesnensia. T. 20: 2006 s. 283-290.

146. STĘPKOWSKI Dariusz: Sprawa domu Herbarta w Królewcu (na podstawie dokumentów odnalezionych w Olsztynie). Prz. Hist.-Ośw. R. 50: 2007 nr 3 s. 149-172.

Johann Friedrich Herbart (1776-1841), filozof i pedagog.

147. STINIA Maria: Rozwój krakowskich gimnazjów państwowych w latach 1867-1918. W: Problemy cywilizacyjnego rozwoju Białorusi, Polski, Rosji i Ukrainy od końca XVIII do XXI wieku. Pod red. Piotra Franaszka, Aleksandra N. Nieczuchrina. Kraków 2007 s. 271-277.

148. SUPADY Jerzy, Biegańska-Płonka Maria: Kolonie letnie dla dzieci w Łodzi na przełomie XIX i XX wieku. Arch. Hist. i Filoz. Med. T. 70: 2007 s. 76-79, streszcz., sum. 
149. SZOT Adam: Polskie szkoły ludowe w parafii Zabłudów w latach 1915-1919. Rocz. Zabłud. T. 1: 2007 s. 52-56.

150. WAJDA Kazimierz: Maturzyści Gimnazjum Kwidzyńskiego (1842-1914) i Gimnazjum Chojnickiego (1883-1913). Pochodzenie społeczne i wybór kierunku studiów. W: Nad Bałtykiem. W kręgu polityki, gospodarki, problemów narodowościowych i społecznych w XIX i XX wieku. Księga jubileuszowa poświęcona profesorowi Mieczysławowi Wojciechowskiemu. Zbiór studiów. Pod red. Zbigniewa Karpusa, Jarosława Kłaczkowa, Mariusza Wołosa. Toruń 2005 s. 177-188.

151. WAŚKIEWICZ Michał: Szkoła organistowska w Przemyślu (1838-1914). Premislia Christiana. T. 12: 2006/2007 [dr.:] 2007 s. 399-436, sum.

152. WNĘK Jan: Polska myśl pedagogiczna 1795-1863. Kraków 2007 Wydaw. MCDN ss. 295.

153. WODZIANOWSKA Irena: Rzymskokatolicka Akademia Duchowna w Petersburgu 1842-1918. Lublin 2007 TN KUL Jana Pawła II ss. 318, nlb. 1, il., rez. TN KUL Jana Pawła II. (Źródła i Monografie; 320).

154. WOŁCZUK Janina: Rosja i Rosjanie w szkołach Królestwa Polskiego 1833-1862. Szkice do obrazu. Wrocław 2005 Wydaw. Uniw. Wrocławskiego ss. 395, il.

Rec.: Radzik Tadeusz, Prz. Hist.-Ośw. R. 50: 2007 nr 1/2 s. 221-225.

155. WOŁOS Mariusz: Józef Beck jako uczeń Cesarsko-Królewskiej I Szkoły Realnej w Krakowie w latach 1908-1912. (Przyczynek do biografii). W: Nad Bałtykiem. W kręgu polityki, gospodarki, problemów narodowościowych i społecznych w XIX i XX wieku. Księga jubileuszowa poświęcona profesorowi Mieczysławowi Wojciechowskiemu. Zbiór studiów. Pod red. Zbigniewa Karpusa, Jarosława Kłaczkowa, Mariusza Wołosa. Torun 2005 s. 1193-1202.

\section{Okres 1918-1939}

156. BUDREWICZ Zofia: Cygan w międzywojennych podręcznikach do kształcenia literackiego. W: Romowie w Polsce i Europie. Historia, prawo, kultura. Pod red. Piotra Borka. Kraków 2007 s. $41-58$.

157. GLIMOS-NADGÓRSKA Anna: Autochtoni na Górnym Śląsku wobec tendencji centralizacyjnych w szkolnictwie polskim 1922-1939. W: Józef Chlebowczyk. Badacz procesów narodotwórczych w Europie XIX i XX wieku. Pod red. Marii Wandy Wanatowicz. Katowice 2007 s. $318-338$.

158. GLIMOS-NADGÓRSKA A.: Niemieckie dziedzictwo kulturowe a elementy prawa niemieckiego obowiązujące w szkolnictwie powszechnym międzywojennego województwa śląskiego. Pr. Nauk. UŚ w Katowicach. Nr 2483: Wieki Stare i Nowe. T. 5: 2007 s. 204-215, sum., Zsfg.

159. GRADOWSKI Henryk: Romantyzm w międzywojennych podręcznikach dla szkół średnich. W: Od oświecenia ku romantyzmowi i dalej... Autorzy, dzieła, czytelnicy. Cz. 2. Pod red. Marka Piechoty i Janusza Ryby. Katowice 2007 s. 175-195.

160. JUŚKO Edmund: Postać Marszałka w działalności wychowawczej szkół powszechnych powiatu tarnowskiego w latach 1918-1939. W: Józef Piłsudski. Historia, tradycja, edukacja. Materiały pomocnicze do nauczania historii Polski XIX i XX wieku. Pod red. Edmunda Juśko. Tarnów 2006 s. 226-238. 
161. KOŁTUN Weronika Barbara: Realizacja wychowania ideowego w szkołach powszechnych powiatu zamojskiego w latach 1918-1939. Lub. Rocz. Pedag. T. 26: 2006 s. 213-227.

162. KOZERA Andrzej: Oświata w myśli politycznej polskiej prawicy społecznej w latach 1918-1939. Kielce 2004 Zakł. Poligraficzno-Wydawniczy „U poety” ss. 66.

163. KRÓL Ewa: Żydowskie organizacje oświatowe i kulturalne w Łęcznej w okresie międzywojennym. Merkuriusz Łęczyński. Nr 17: 2004 s. 15-16.

164. LWOWSKI Album. Nauka, zabawa, polityka i awantura. Korporanci i Wszechpolacy w życiu akademickim Lwowa. Lata 30-ste XX wieku. [Oprac. Wojciech Jerzy Muszyński, Krzysztof Kaczmarski]. Glaukopis. Nr 5/6: 2006 s. 73-117, 119-180, 182-205.

Z treści: Wawrzków Jan: Lwowska Młodzież Wszechpolska. Uwagi na temat działalności, zaplecza i środowiska 1935-1939 s. 73-99; Zakrzewski Zdzisław: Na Politechnice Lwowskiej s. 109-113; Zaleszczyk Helena z d. Pisarek: Wspomnienia. Fragmenty z okresu studiów we Lwowie 1936-1939 s. 114-117; Łucki Stanisław: Studia z przygodami s. 127-138; Czarniecki Józef: Narodowa Organizacja Gimnazjalna w Tarnopolu. Uczniowska konspiracja 1899-1939 s. 139-147; W obronie autonomii wyższych uczelni 1933 s. 148-150; Blicharski Czesław E.: Tarnopolska NOG-a i lwowscy Wszechpolacy. W II Gimnazjum Państwowym w Tarnopolu. [Narodowa Organizacja Gimnazjalna] s. 151-180; Popławski Zbysław: Urywki lwowskich wspomnień. Powstanie Korporacji Akademickiej „Slavia” s. 184-205.

165. ŁAPOT Mirosław: Kształcenie wychowawców żydowskich domów sierot w Małopolsce w okresie międzywojennym. Prz. Hist.-Ośw. R. 50: 2007 nr 1/2 s. 41-52.

166. MAJCHRZYK-MIKUŁA Joanna: Początki opieki medycznej w szkołach na ziemiach polskich. Arch. Hist. i Filoz. Med. T. 70: 2007 s. 80-85, streszcz., sum.

167. MARCHEWKA Dariusz: Żydowscy akademicy z Kutna i powiatu kutnowskiego na uczelniach zagranicznych 1918-1939. Kutn. Zesz. Region. T. 11: 2007 s. 379-400.

168. MĄCZKA Dorota: Oświata w powiecie siedleckim 1918-1939. Rocz. Bial.-Podl. T. 14: 2006 s. $105-128$.

169. MEZGLEWSKI Artur: Szkolnictwo średnie w dobie reform systemu oświaty w II Rzeczypospolitej Polskiej. W: Historia magistra vitae. Księga jubileuszowa ku czci profesora Jerzego Flagi. Red. Antoni Dębiński. Lublin 2007 s. 255-266.

170. ODZIEMKOWSKI Janusz: Wychowanie patriotyczne i obywatelskie w Siłach Zbrojnych II Rzeczypospolitej. W: Polski obyczaj patriotyczny od XVIII do przełomu XX/XXI w. - ciągłość i zmiana. Pod red. nauk. Andrzeja Stawarza i Wiesława Jana Wysockiego. Warszawa 2007 s. $173-184$.

171. OLSTOWSKI Przemysław: Szkoły wydziałowe w Toruniu lat Drugiej Rzeczypospolitej. Rocz. Tor. [T.] 33: 2006 [dr.:] 2007 s. 119-147, sum., Zsfg.

172. POLAK Ryszard: Religia rzymskokatolicka w szkołach II Rzeczypospolitej. Lublin 2007 Polihymnia ss. 462, sum., Zsfg.

173. PRZENIOSŁO Marek: Sprawa niegospodarności w Oddziale Lwowskim Związku Profesorów Szkół Akademickich. W: Znani i nieznani międzywojennego Lwowa. Studia i materiały. Pod red. Marka Przeniosło i Lidii Michalskiej-Brachy. Kielce 2007 s. 123-132. 
174. PUDŁOCKI Tomasz: Pomiędzy ideałem a rzeczywistością. Życie codzienne uczniów Gimnazjum Morawskiego w Przemyślu w okresie międzywojennym. Wybrane zagadnienia. Rocz. Przem. R. 43: 2007 z. 4 s. 169-178.

175. REĆKO Jan: Wychowanie dzieci i młodzieży w polityce rządów obozu Józefa Piłsudskiego w latach 1926-1939. W: Myśl polityczna Józefa Piłsudskiego. Pod red. nauk. Wiesława Leszka Ząbka. Warszawa 2007 s. 173-179.

176. SIERŻĘGA Paweł: „Wiadomości Historyczno-Dydaktyczne” 1933-1939. W: Wielokulturowe środowisko historyczne Lwowa w XIX i XX w. T. 5. Pod red. Jerzego Maternickiego, Leonida Zaszkilniaka. Rzeszów 2007 s. 476-499.

177. SKŁADANOWSKI Henryk: Postać Józefa Piłsudskiego w podręcznikach do nauczania historii w szkołach powszechnych II Rzeczypospolitej. W: Józef Piłsudski wobec Europy i wybranych zagadnień wewnętrznych Drugiej Rzeczypospolitej (1918-1935). W 70. rocznicę śmierci. Studia. Pod red. Mieczysława Wojciechowskiego i Zbigniewa Karpusa. Toruń-Włocławek 2007 s. $183-195$.

178. [SKÓRCZYŃSKI Leon]: Leona Skórczyńskiego „Strajk nauczycieli we Włocławku i pow. włocławskim (ze wspomnień autora)". [Wyd.] Bogdan Ziółkowski. Zap. Kuj.-Dobrz. T. 22: 2007 s. $115-127$.

$9-10 \times 1937$ r.

179. SKRZYPEK Miłosz: Organizacja i podstawy prawne funkcjonowania polskiego szkolnictwa na Śląsku Cieszyńskim w latach 1920-1922. Pr. Nauk. UŚ w Katowicach. Nr 2483: Wieki Stare i Nowe. T. 5: 2007 s. 187-203, sum., Zsfg.

180. SZCZEPAŃSKA Beata: Czasopiśmiennictwo pedagogiczne i medyczne jako źródło do badań nad historią higieny szkolnej w Drugiej Rzeczypospolitej. Arch. Hist. i Filoz. Med. T. 70: 2007 s. 145-147, streszcz., sum.

181. SZLAWSKI Dariusz: Nauczyciele w samorządzie Zgierza w latach Drugiej Rzeczypospolitej. Rocz. Łódz. T. 53: 2006 s. 161-186, Zsfg.

182. SZULAKIEWICZ Władysława: Członkowie lwowskiego Oddziału Komisji do Badania Dziejów Wychowania i Szkolnictwa w Polsce (1920-1929). W: Wielokulturowe środowisko historyczne Lwowa w XIX i XX w. T. 5. Pod red. Jerzego Maternickiego, Leonida Zaszkilniaka. Rzeszów 2007 s. 386-394.

183. TUROS Lucjan: Solorzowa Rzeczpospolita Spółdzielcza (Aktualność koncepcji I[gnacego] Solorza w zakresie wychowania do spółdzielczości i samorządności młodzieży wiejskiej). Prz. Hum. R. 47: 2003 nr 4 s. 55-65, sum.

184. TYLIŃSKA Ewelina: Obraz społeczności studenckiej na łamach polskiej prasy wileńskiej w okresie międzywojennym. Kw. Hist. Nauki i Techn. R. 52: 2007 nr 2 s. 179-194.

185. TYLIŃSKA E.: Wpływ środowiska akademickiego w Wilnie w latach 1919-1939 na działalność miejskich placówek muzealnych i bibliotecznych. Kw. Hist. Nauki i Techn. R. 52: 2007 nr 3/4 s. 265-288.

186. WABISZCZEWICZ Aleksander: Oświata i kultura Żydów na terytorium województwa poleskiego w latach 1921-1939. Kw. Hist. Żydów. [R. 7]: 2007 nr 3 s. 285-293, sum.

187. WAGNER Wieńczysław: Włosko-polska umowa akademicka z 1938 roku. Relacja prof. Wienczysława Wagnera von Igelgrund zum Zornstein opowiedziana 13 września 1992 na spotka- 
niu ze studentami: University of Virginia w Miller Center of Public Affairs the Kościuszko Chair of Polish Studies, Charlottesville, Virginia. Glaukopis. Nr 1: 2003 s. 61-63.

188. WALASEK Stefania: Zagadnienie kwalifikacji nauczycieli szkół powszechnych II Rzeczypospolitej. W: Między Lwowem a Wrocławiem. Księga jubileuszowa profesora Krystyna Matwijowskiego. Pod red. Bogdana Roka i Jerzego Maronia. Toruń 2006 s. 939-948.

189. WALEWANDER Edward: Pedagogia katolicka w diecezji lubelskiej 1918-1939. Przedm. Kalina Bartnicka. Lublin 2007 Tow. Nauk. KUL ss. 366, tabl. 49, il., Zsfg. Akad. Hum. im. Aleksandra Gieysztora w Pułtusku, Tow. Nauk. KUL. (Biblioteka Pedagogiczna Katedry Pedagogiki Porównawczej Wydziału Nauk Społecznych Katolickiego Uniwersytetu Lubelskiego. Ser. A: Studia; t. 11) (Prace Wydziału Nauk Społecznych; 109).

Rec.: Tymosz Stanisław, Roczniki Nauk Prawnych. T. 17: 2007 nr 2 s. 233-236; Wieliczko Mieczysław, Rocz. Chetm. T. 11: 2007 s. 288-291.

190. WYSOCKI Tomasz: Struktura wyznaniowa studentów i absolwentów uczelni wyższych w roku akademickim 1937/1938. Prz. Hist.-Ośw. R. 50: 2007 nr 1/2 s. 111-132.

191. ZAJĄC Wojciech: Filozoficzno-ideologiczny kontekst oświaty polskiej w okresie międzywojennym. Katowice 2007 Wydaw. Uniw. Śląskiego ss. 238, nlb. 2. (Prace Naukowe Uniwersytetu Śląskiego w Katowicach; nr 2518).

192. ZAKRZEWSKA Aldona: Związek Strzelecki 1919-1939. Wychowanie obywatelskie młodzieży. Kraków 2007 Impuls ss. 351, il.

193. ZAMOJSKA Dorota: „Drugi organ państwa polskiego”. Powstanie warszawskich wyższych uczelni oraz kształcenie centralnych polskich władz oświatowych i naukowych w dobie odbudowy państwa polskiego. W: O polskich elitach raz jeszcze. Studia ofiarowane profesor Janinie Leskiewiczowej z okazji dziewięćdziesiątych urodzin. Red. Tadeusz Epsztein, Sławomir Górzyński, Andrzej Karpiński. Warszawa 2007 s. 201-258.

\section{Okres 1939-1945}

194. ADAMCZYK Mieczysław: Szkolnictwo i oświata w konspiracyjnej prasie ludowej. W: Dzieje partii i stronnictw chłopskich w Europie. T. 1: Narodziny i rozwój. Kom. red. Józef Ryszard Szaflik [i in.]. Pułtusk-Warszawa 2007 s. 615-622.

195. BIEGAŃSKA Olga: Spuścizny profesorów tajnego Uniwersytetu Ziem Zachodnich jako źródło do badań tajnego nauczania w Generalne Guberni. W: Pamiętnik VIII Ogólnopolskiego Zjazdu Studentów Archiwistyki. (Archiwista w świecie źródeł historycznych). Lublin, 28-29 kwietnia 2005. Pod red. Janusza Łosowskiego. Lublin 2007 s. 41-46.

196. EJANKOWSKI Jan: Nasi męczennicy Krwawej Kociewskiej Jesieni. Rocz. Gniew. [T.] 1: 2004 s. 19-22.

Zamordowanie przez hitlerowców jesienią 1939 r. nauczycieli - Franciszka Widźgowskiego i Jana Drosta.

197. GROCHOWINA Sylwia: Niemieckie szkolnictwo średnie ogólnokształcące w Toruniu w latach 1939-1945. Rocz. Tor. [T.] 34: 2007 s. 121-140, sum., Zsfg. 
198. KORNEĆ Grażyna: Tajna oświata na południowym Podlasiu i wschodnim Mazowszu 1939-1944. Siedlce 2006 Wydaw. Akad. Podlaskiej ss. 611, tabl. 40, il. Akad. Podlaska. (Monografie; nr 64).

Rec.: Charczuk Wiesław, Rocz. Hist. MHPRL. Nr 23: 2007 s. 261-263.

199. LACH Monika: Tajne nauczanie w Wołominie w latach 1939-1944. Rocz. Wołom. T. 3 : 2007 s. 76-94.

200. MIKITIUK Renata: Ustrój polskiego szkolnictwa powojennego w okupacyjnych programach partii politycznych i organizacji oświatowych. Krak. Studia Małop. Nr 11: 2007 s. 301-309.

201. MIKITIUK R.: Zakres i organizacja tajnego nauczania na Lubelszczyźnie podczas II wojny światowej. Krak. Studia Małop. Nr 11: 2007 s. 219-237, sum.

202. PACZYŃSKA Irena: „Aktion gegen Universitätsprofessoren” w listopadzie 1939 r. oraz działania na rzecz uwolnienia uczonych. W: Studia Lodomeriana. Historia, kultura, prawo. Pod red. Karoliny Grodziskiej i Grzegorza Niecia. Kraków 2007 s. 143-151.

203. SAMULEWSKA Alicja: Zachowani w pamięci uczniów. Rocz. Gniew. [T.] 1: 2004 s. $23-25$.

Zamordowanie przez hitlerowców jesienią 1939 r. gniewskich nauczycieli - Alojzego Gardzielewskiego i Edwarda Zajączka.

\section{Okres 1945-1989}

204. BĘDŹMIROWSKI Jerzy: Uczelnie cywilne a Marynarka Wojenna RP po 1945 roku. Nautologia. R. 41: 2006 s. 2-10.

205. BOHDAN Mieczysław: Oświata świebodzińska w okresie powojennym. W: Dzieje Świebodzina. Pod red. Wojciecha Strzyżewskiego. Zielona Góra-Świebodzin 2007 s. 399-418.

206. BYDLIŃSKA Urszula: Podręczniki do historii w okresie PRL jako nośnik propagandy politycznej i forma indoktrynacji młodzieży szkolnej. Koło Historii. Nr 7: 2003 s. 65-71.

207. CEYNOWA Tadeusz: Starania biskupa Ignacego Jeża o utworzenie Wyższego Seminarium Duchownego w Koszalinie. Studia Koszalińsko-Kołobrzeskie. Nr 11: 2007 s. 23-32.

Lata $1972-1981$.

208. CHMIELEWSKI Witold Jan: Edukacja nauczycieli szkół podstawowych po II wojnie światowej. Warszawa 2007 Neriton ss. 233, nlb. 1, sum.

Do 1956 r.

209. CHMIELEWSKI W. J.: Kształcenie nauczycieli w okresie ideologizacji szkolnictwa (1944-1956). Warszawa 2006 Neriton ss. 385, nlb. 4, sum.

210. CIEMIĘGA Katarzyna: Alumni w Wojsku Polskim w latach 1959-1980 w świetle dokumentów Głównego Zarządu Politycznego WP. Biul. Wojsk. Stużby Archiw. Nr 28: 2006 [dr.:] 2007 s. 252-266.

211. FELCHNER Andrzej: Niektóre problemy piotrkowskiej oświaty po wyzwoleniu spod okupacji niemieckiej. W: W kręgu literatury i języka. Praca zbior. pod red. Anny Grochulskiej. Piotrków Trybunalski 2005 s. 149-164. 
212. FILIP Magdalena: Uczniowska kontestacja. Historia rzekomej Bojowej Organizacji Antyradzieckiej. Kron. M. Łodzi. 2007 [nr] 3 s. 131-137.

$1962 \mathrm{r}$.

213. FUDALI Robert: Heteronomiczny charakter ról społecznych nauczycieli w warunkach ustroju totalitarnego w Polsce 1945-1989. Prz. Hist.-Ośw. R. 50: 2007 nr 1/2 s. 97-109.

214. GAŁASZEWSKI Dariusz: Postawy młodzieży wobec przymusowego werbunku i pracy w brygadach Powszechnej Organizacji „Służba Polsce” w latach 1948-1955. Pamięć i Sprawiedliwość. 2007 [nr] 1 s. 245-272, sum.

215. GŁĘBOCKI Henryk: Sieć agentury SB na uczelniach wyższych w PRL (na przykładzie Krakowa w latach 80. XX w.). Arcana. Nr 74/75: 2007 s. 303-324.

Zawiera też dokumenty SB z 1. 1985-1986.

Polem.: Paczkowski Andrzej, Tamże. Nr 76: 2007 s. 207; Repl.: Głębocki H., Tamże s. 207-208.

216. GŁĘBOCKI H.: Uniwersytety pod lupą SB. W: Agentura w akcji. Pod red. Filipa Musiała i Jarosława Szarka. Kraków 2007 s. 163-172. (Z Archiwów Bezpieki - Nieznane Karty PRL; t. 4).

217. JANOWSKI Włodzimierz: Młodzież i jej organizacje wobec wydarzeń politycznych 1956 roku. Zarys problematyki. W: Październik 1956 roku. Początek erozji systemu. Praca zbiorowa. Pod red. Marka Jabłonowskiego, Stanisława Stępki. Pułtusk 2007 s. 141-165.

218. JAROSZ Dariusz: Nauka i edukacja w stosunkach polsko-francuskich w latach 1971-1980. Analecta. R. 16: 2007 z. 1/2 s. 283-315, sum.

219. KOKOSZKO Marta: Zasada laicyzacji a praktyka szkolna. W: Dolnoślązacy? Kształtowanie tożsamości mieszkańców Dolnego Śląska po II wojnie światowej. Red. Joanna Nowosielska-Sobel, Grzegorz Strauchold. Wrocław 2007 s. 141-149.

220. KOWALSKI Tadeusz: Kształtowanie się szkolnictwa powiatu pułtuskiego w latach 1944 -1946. Rocz. Maz. T. 19: 2007 s. 174-192.

221. KOZAK Marzena: Kara śmierci dla Bronisława Kozaka. Kulisy ubeckiej zbrodni sądowej (1952). Sprawa gimnazjalistów szprotawskich. Wrocław 2007 Gajt Wydaw. ss. 120, il.

222. KRASUCKI Eryk: Alternatywne ruchy młodzieżowe wobec zmian społeczno-politycznych końca lat 80 . XX wieku. Zarys problematyki ze szczególnym uwzględnieniem obszaru Pomorza Zachodniego. W: Narodziny III Rzeczypospolitej. Pomorze Zachodnie w latach 1988-1990. Materiały z sesji naukowej. Red. Małgorzata Machałek, Jan Macholak. Szczecin 2006 s. $177-189$.

223. KULBAKA Jacek: Działalność Sekcji Szkolnictwa Specjalnego w pierwszym dziesięcioleciu po II wojnie światowej. Biul. Hist. Wychowania. 2005/2006 [dr.:] 2007 [nr] 1/2 s. 58-74.

224. KULBAKA Jacek: Szkolnictwo specjalne w pracach ministerstwa oświaty w okresie przygotowań i realizacji planu sześcioletniego (1950-1955). Prz. Hist.-Ośw. R. 50: $2007 \mathrm{nr}$ 1/2 s. $187-203$.

225. KULIŃSKI Sebastian: Trudne świętowanie. Rocznica siedemdziesięciolecia urodzin oraz śmierci Stalina w propagandzie partyjnej w wyższych uczelniach Krakowa, Łodzi i Wrocławia w 1949 i 1953 roku. W: Od Napoleona do Stalina. Studia z dziejów XIX i XX wieku. Pod red. Teresy Kulak. Toruń 2007 s. 251-267. 
226. KUŹMA Ewa: Organizacja szkolnictwa rolniczego w lubelskim okręgu szkolnym w latach 1944-1950. Krak. Studia Małop. Nr 11: 2007 s. 202-218, sum.

227. MACHALIŃSKI Zbigniew: Pomoc Szwecji w uruchomieniu Akademii Lekarskiej w Gdańsku (1945-1948). W: Polska Szwecja w XX wieku. Wpływy i inspiracje. Studia pod red. Jana Szymańskiego. Gdańsk-Sopot 2007 s. 67-75.

228. MARECKI Józef: Likwidacja niższych seminariów zakonnych na terenie woj. krakowskiego w 1952 r. W: Kościół katolicki w czasach komunistycznej dyktatury. Między bohaterstwem a agenturą. Pod red. Ryszarda Terleckiego i Jana Szczepaniaka. Kraków 2007 s. 135-164.

229. MURANYI Roman: Niektóre aspekty programowe i organizacyjne kształcenia instruktorów harcerskich po Zjeździe Łódzkim. Rocz. Hist. Harcerstwa. [T.] 3: 2007 s. 45-63.

Lata 1956-1961.

230. NOWAKOWSKI Andrzej: Szkolne wychowanie fizyczne w ustawodawstwie oświatowym PRL. W: Szkice z dziejów ustroju i prawa Polski. In memoriam dr Krzysztof Brześkiewicz. Praca zbiorowa. Pod red. A. Nowakowskiego. Rzeszów 2006 s. 129-148.

231. NOWARSKI Czesław: Kraków średniowieczny w języku szkolnych podręczników historii (1945-1989). W: Kraków. Studia z dziejów miasta. W 750 rocznicę lokacji. Pod red. nauk. Jerzego Rajmana. Kraków 2007 s. 261-277.

232. PELKA Anna: Teksas-land. Moda młodzieżowa w PRL. Warszawa 2007 Trio ss. 263, il. (W Krainie PRL).

233. PILARCZYK Władysław: Początki szkolnictwa w Lipnicy Wielkiej po II wojnie światowej. W: Z dziejów Lipnicy Wielkiej. Orawa. R. 18/19: 2007 s. 29-41.

234. PLICHTA Pawel: „Odrodzenie Harcerstwa i walka o jego oblicze ideowe w latach 1956-1959” - konferencja naukowa (Kraków, 4 grudnia 2006). Studia Hist. R. 50: 2007 z. 2 s. $255-256$.

235. POGORZAŁA Ewa: Szkolnictwo ukraińskie w województwie lubelskim w latach 1944-1946. Prz. Hist.-Ośw. R. 50: 2007 nr 1/2 s. 63-79.

236. POLAŃSKA Mariola: Z dziejów szkolnictwa podstawowego na Pałukach - rola „tysiąclatek". W: Pałuki - ludzie, wydarzenia, miejsca. Wybrane zagadnienia z przeszłości regionu. Materiały opracowane na podstawie sesji popularno-naukowej, która odbyła się 26 września 2007 r. w Szubinie. Red. Kamila Czechowska. Szubin 2007 s. 104-123.

237. PULIŃSKI Andrzej Jarosław: Konspiracja i opór. Z dziejów oświaty na Warmii i Mazurach w latach 1945-1956. Białystok 2007 Wydaw. Niepańst. Wyższej Szkoły Pedag. ss. 191.

238. RADZISZEWSKA Maria: Potrzeby kadrowe szkolnictwa powszechnego na Warmii i Mazurach w latach 1945-1948. Biul. Hist. Wychowania. 2005/2006 [dr.:] 2007 [nr] 1/2 s. 86-94.

239. RYBA Mieczysław: Szkoła w okowach ideologii. Szkolna propaganda komunistyczna w latach 1944-1956. Lublin 2006 Fund. Servire Veritati. Inst. Edukacji Nar. ss. 138, nlb. 1.

240. SADOWSKA Joanna: Niepublikowane badania ankietowe - rys do portretu młodzieży u schyłku epoki gomułkowskiej. Dzieje Najn. R. 39: 2007 [nr] 3 s. 111-120, sum.

Prowadzone pod kierunkiem Albina Klementowskiego w 1970 r. 
241. SĘKOWSKI Paweł: Udział Polskiej Partii Socjalistycznej w działalności Towarzystwa Uniwersytetu Robotniczego w Krakowie w latach 1945-1948. Studia Hist. R. 50: 2007 z. 3/4 s. 333-348, sum.

242. SIKORA Mirosław: Kierunki działań operacyjnych Służby Bezpieczeństwa wobec inteligencji technicznej na przykładzie kadry naukowej Politechniki Śląskiej i Politechniki Częstochowskiej. Aparat Represji w Pol. Lud. 1944-1989. T. 4: 2007 z. 1 s. 152-196.

243. STĘPKA Stanisław: Społeczny Fundusz Budowy Szkół Tysiąclecia (1958-1966). Studia Hist. R. 50: 2007 z. 2 s. 233-242.

244. WĄSOWICZ Jarosław: Likwidacja salezjańskich zakładów wychowawczych. Biul. IPN. 2007 nr 4 s. $49-56$.

245. WITEK Danuta: Szkolnictwo podstawowe powiatu chełmskiego w latach 1944-1961. Rocz. Chetm. T. 10: 2006 s. 307-330.

246. WITEK D.: Szkolnictwo podstawowe powiatu radzyńskiego w XXX-leciu powojennym. Zbiór dokumentów z lat 1944-1975. Radzyń Podlaski 2007 Danuta Witek; Radzyński Ośr. Kultury i Rekreacji ss. 160 , il.

247. WOŁOSZYN Jacek Witold: Chronić i kontrolować. UB wobec środowisk i organizacji konspiracyjnych młodzieży na Lubelszczyźnie (1944-1956). Warszawa 2007 IPN-KŚZpNP ss. 735, nlb. 1, il., sum. IPN-KŚZpNP. (Monografie; t. 35).

248. WOŁOSZYN J.: Udział organów bezpieczeństwa w akcji rekrutacji na studia w województwie lubelskim w latach 1947-1956. Pamięć i Sprawiedliwość. 2007 [nr] 1 s. 193-226, sum.

Zawiera też dokumenty.

249. ZARADNY Ryszard: Polityka oświatowa w Zielonej Górze w pierwszym dziesięcioleciu powojennym. Rocz. Lubus. T. 33: 2007 cz. 1 s. 53-71, sum.

250. ZWIERNIK Przemysław: Młodzieżowe organizacje niepodległościowe w Wielkopolsce. W: Konspiracja antykomunistyczna i podziemie zbrojne w Wielkopolsce w latach 1945-1956. Pod red. Agnieszki Łuczak i Aleksandry Pietrowicz. Poznań 2007 s. 33-45. (Studia i Materiały IPN).

251. ŻERELIK Rościsław: Integracyjna rola szkoły na Dolnym Śląsku na przykładzie Szkoły Podstawowej w Szczepanowie. W: Dolnoślązacy? Kształtowanie tożsamości mieszkańców Dolnego Śląska po II wojnie światowej. Red. Joanna Nowosielska-Sobel, Grzegorz Strauchold. Wrocław 2007 s. $151-161$.

\section{Okres 1989-2007}

252. GAŁKOWSKI Adam: Konferencja Rektorów Akademickich Szkół Polskich (1997-2007). Z dziejów autonomii uczelni i samorządności akademickiej w Polsce. Kraków 2007 Fund. dla UJ ss. 206, nlb. 1, tabl. 56, il.

253. GERYK Marcin: Rynek uczelni niepublicznych w Polsce. Warszawa 2007 Szkoła Główna Handlowa. Oficyna Wydawnicza ss. 210, il. 
254. KADRY morskie Rzeczypospolitej. T. 4: Polska Marynarka Handlowa. Absolwenci uczelni morskich Gdyni i Szczecina 2000-2005. Pod red. Jana Kazimierza Sawickiego; tł. na ang. Barbara Thun. Gdynia 2007 Akad. Morska ss. CXXVIII, 329, nlb. 4, il.

T. 1. 1994.

255. KWADRANS Łukasz: Charakterystyka sytuacji edukacyjnej Romów w Czechach, Polsce i Słowacji po 1989 roku. W: Romowie w Polsce i Europie. Historia, prawo, kultura. Pod red. Piotra Borka. Kraków 2007 s. 233-248.

256. POGORZAŁA Ewa: Szkolnictwo mniejszości narodowych i etnicznych w Polsce w okresie transformacji. W: Mniejszości narodowe i etniczne w procesach transformacji oraz integracji. Pod red. Elżbiety Michalik i Henryka Chałupczaka. Lublin 2006 s. 327-338.

257. REJMAN Aneta: Struktury organizacyjne Szkolnego Związku Sportowego na Podkarpaciu w latach 1989-2005 (zarys problematyki). W: Szkice z historii oraz organizacji kultury fizycznej i turystyki in memoriam Stanisław Podobiński et Andrzej Wasiak. Praca zbior. pod red. Andrzeja Nowakowskiego. Wadowice 2007 s. 57-66.

258. ŚLIWERSKI Bogusław: Oświatowa „przeprowadzka” z III RP. Rocz. Pedag. T. 30: 2007 s. 21-37.

Reforma systemu edukacji.

\section{Oświata polonijna}

259. BIBRO Anna: Na „stałce”. Bogumiłowice 2007 Anna Bibro ss. 192.

Wspomnienia z pracy nauczycielki w polskiej szkole w Belgii.

260. BUTRYMOWICZ Maria: O kształceniu nauczycieli klas początkowych szkół polskich na Litwie (w kontekście historycznym i w warunkach transformacji ustrojowej państwa). Rocz. PTN na Obczyźnie. R. 49: 2005/2006 [dr.:] 2007 s. 87-102.

XX w.

261. DZIUBEK Alojzy młodszy: Walka o polskie liceum na Orawie. Orawa. R. 18/19: 2007 s. $115-136$.

Wspomnienia z 1. 50. XX w.

262. POLSKI Uniwersytet na Obczyźnie (PUNO). Sprawozdanie z działalności w roku akademickim 2005/2006. Rocz. PTN na Obczyźnie. R. 49: 2005/2006 [dr.:] 2007 s. 137-148.

263. ROKICKA Anna: Dziennik nauczycielki z Kazachstanu. Cz. 2. My, Sybiracy. Nr 18: 2007 s. $248-264$.

Zapiski nauczycielki jęz. polskiego z 1. 1992-1995; Cz. 1. Tamże. Nr 17: 2006.

264. STANISZEWSKI Adam: Problemy polskiej oświaty w Szwecji w latach 1939-1945. W: Historia i polityka. Tom specjalny doktorancki. Pod red. Huberta Stysa. Toruń 2007 s. 63-78.

265. SZWAGRZAK Bogdan: Emigracyjne organizacje młodzieżowe w Wielkiej Brytanii. W: Rola dawnej i nowej emigracji w warunkach Unii Europejskiej. Red. Wanda Lohman. Kraków 2006 s. $123-149$.

266. VALENTIN-STĄCZEK Ewa: Les Villardiens. Biographies. La création et vie du Lycée Polonais a Villard de Lans 1940-1946. Trad. de pol. par Marie Irene Malewiak et Barbara Pawłowska. Wrocław 2007 Ewa Valentin-Stączek ss. 565, nlb. 1, il. 
Tyt. oryg.: Villardczycy. Życiorysy. Powstanie i funkcjonowanie polskiego liceum w Villard de Lans 1940-1946. Wrocław 2003.

267. WOLNICKI Paweł: Powstanie Veritas - okręg Szwajcaria. Rocz. Bibl. Nauk. PAU i PAN Kr. R. 52: 2007 s. 421-439, sum.

Polskie Katolickie Stowarzyszenie Uniwersyteckie Veritas, powstałe w 1946 r.

268. ZAWADA Stefania: Polska szkoła w Nowej Zelandii. Ze wspomnień i innych źródeł. W: Z Sybiru na drugą półkulę. Wojenne losy polskich dzieci z Pahiatua. Lublin 2007 s. 167-190.

\section{DZIEJE SZKÓŁ RÓŻNYCH STOPNI}

\section{Szkoły podstawowe i zakłady wychowawcze}

269. GLINICA - zarys dziejów. Red. Edward Pawołka, Józef Bremer. Glinica 2007 Rada Sołecka ss. 114, tabl. 18, il., Zsfg.

Księga pamiątkowa w 100-lecie Szkoły Podstawowej w Glinicy.

270. GNIEWSKIE szkoły w XIX i XX wieku]. Rocz. Gniew. [T.] 2: 2005 s. 6-14, 20-27, 34-44.

271. HISTORIA daleka i bliska. Suwalska szkoła z tradycjami. Oprac. zespół w składzie Jadwiga Błażewicz [i in.]. Białystok-Suwałki 2007 Libra Wydaw. i Drukarnia PPHU; Zespół Szkół nr 5 ss. 224, il.

Zespół Szkół nr 5 w Suwałkach.

272. HISTORIA szkolnictwa podstawowego w Janikowie. Janikowo 2007 Tow. Przyj. Janikowa ss. 195 , il.

XX-XXI w.

273. HISTORIA Szkoły w Głogoczowie. O ważnych wydarzeniach w 150-leciu szkoły. Red. Bolesław Malinowski, Renata Faron, Edyta Szeląg. Głogoczów-Kraków 2007 Wydaw. i Drukarnia Tow. Słowaków w Polsce ss. 82, nlb. 1, il.

XIX-XXI w.

274. KACHNIARZ Teresa, Kuna Barbara, Wierzbicka Iwona: Przygoda z turystyką. Chełmża 2007 Pow. i MBP im. Juliana Prejsa ss. 79, il.

Szkolne Koło Krajoznawczo-Turystyczne PTTK nr 16 przy Szkole Podstawowej nr 3 w Chełmży, po $1945 \mathrm{r}$

275. KRĘŻEL Janusz: Państwowy Dom Dziecka w Mielcu-Smoczce 1947-1952 (zarys). Rocz. Miel. T. 9: 2006 [dr.:] 2007 s. 161-166.

Uzup.: Smaczniak Feliks: Wspomnienie wychowanka Domu Dziecka o Bronisławie Nodze [1906-1966]. Tamże s. 295-297.

276. KUCHA-FRANKIEWICZ Ewa: Zarys dziejów Szkoły Podstawowej nr 35 im. Emilii Plater w Lublinie. Lub. Rocz. Pedag. T. 26: 2006 s. 241-255.

Od 1966 r.

277. LIPIEC Antoni: Dzieje szkoły w Głowaczowie. Oprac. i wyd. Przemysław Zieliński. Wieś Radomska. T. 8: 2007 s. 103-145.

XIX-XX w. 
278. ŁAŻEWSKA Ewa, Chmura Barbara: Łobzowska szkoła w Bronowicach Małych (1831-2004). Bron. Zesz. Hist.-Liter. Z. 19: 2004 s. 14-21.

279. MARCJASZ Czesław: Zarys dziejów szkolnictwa w Górkach Wielkich. Zaranie Śląskie. R. 61: 2004 nr 9 s. 71-76, Zsfg.

XVII-XX w.

280. MILLER Anna, Piotrowska Jolanta: W cieniu Lucjana Rydla (Szkoła Podstawowa nr 93 w latach 1960-2004). Bron. Zesz. Hist.-Liter. Z. 19: 2004 s. 25-28.

281. NOWAKOWSKA Joanna: Historia szkolnictwa specjalnego w Białej Podlaskiej. Rocz. Bial.-Podl. T. 14: 2006 s. 95-103.

XIX-XX w.

282. SIEDEMDZIESIĄT lat służby Polsce (1936-2006). Dzieje Szkoły Powszechnej i Podstawowej nr 46 w Poznaniu. Oprac. Dariusz Matelski. Poznań 2007 Zakł. Poligraf. „Grafika” ss. 364, il.

283. SIELEZIN Elżbieta: Z perspektywy 25-lecia. Krótka historia Zabobrzańskiej „Czwórki”. Rocz. Jel.-Gór. T. 38: 2006 s. 177-184, shrnutí, Zsfg.

Szkoła Podstawowa nr 4 w Jeleniej Górze, od 1981 r.

284. SKOLARUS Brygida: Dzieje Szkoły Podstawowej nr 9 w Słupsku w latach 1957-2007. Wprow. i oprac. red. Jan Wild. Słupsk 2007 Szkoła Podstawowa nr 9 ss. 140, il. (Biblioteka Dziewiątki; $\mathrm{nr}$ 7).

285. SZKOŁA Powszechna w Bronowicach Małych. Bron. Zesz. Hist.-Liter. Z. 23: 2006 s. $3-27$.

Treść: Hausner Wojciech: „Wzniesiony budynek ma być przybytkiem wiedzy...” (lata 30-te) s. 3-9; Młodzież szkolna pomaga w budowie szkoły (Relacja z „Ilustrowanego Kuriera Codziennego” z dnia 5 października 1936 r.). Oprac. Barbara Miszczyk s. 10-11; Rydlowa Maria z Trabków: Stara, niezapomniana szkoła. [Wspomnienia] s. 12-14; Hausner W.: Szkolne archiwalia - ,przymus szkolny” s. 15-17; Kronika wizyt szkoły trywialnej w Bronowicach Małych od r. 1858. (Wpisy z lat 1919-1930) s. 18-26; Szkoła w Bronowicach Małych w prasie krakowskiej („Ilustrowany Kurier Codzienny” z dnia 23 sierpnia 1936 r.) s. 27.

286. WIŚNIEWSKA Julita, Andrys Wiesław: Dzieci romskie w Szkole Podstawowej nr 7 w Świeciu. W: Romowie w Polsce i Europie. Historia, prawo, kultura. Pod red. Piotra Borka. Kraków 2007 s. 272-284.

287. WOJCIECHOWSKI Daniel: „Biskupia” Zespół Szkół Katolickich im. św. Stanisława Kostki w Kielcach. Jubileusz 200-lecia diecezji kieleckiej. Kielce 2005 Wydaw. Jedność ss. 239, nlb. 1, il.

XX-XXI w.

288. WSPOMNIENIA z bronowickiej szkoły. Bron. Zesz. Hist.-Liter. Z. 24: 2007 s. 15-30.

Wspomnienia ze Szkoły Podstawowej w Bronowicach Małych w okresie PRL i III RP - Marka Kudasiewicza, Marii Kozłowskiej, Jana Młodzianowskiego, Alicji Sułkowskiej-Dygut i Justyny Słowikowskiej.

\section{Szkoły średnie ogólnokształcące}

289. ARVANITI Joanna: Nauczyciele i uczniowie Eksperymentalnego Państwowego Liceum im. Jana i Jędrzeja Śniadeckich w Wilnie w zasobie Archiwum Polskiej Akademii Nauk. W: Polsko-litewskie kontakty naukowe w świetle zbiorów archiwalnych i bibliotecznych. Moksliniai lenku-lietuviu kontaktai archyvniu ir bibliotekiniu rinkiniu šviesoje. Red. nauk. J. Arvaniti, Arkadiusz Roszkowski. Warszawa 2004 s. 182-204. 
290. HISTORIA szkoły wspomnieniami pisana. 60 lat Liceum Ogólnokształcącego, jubileusz Zespołu Szkół nr 1 im. Bolesława Krzywoustego w Choszcznie. Wspomnienia zebrała i oprac. Bożena Widła. Choszczno 2006 Kombinat Artystyczny ASz Artur Szuba ss. 102, il.

291. JANECZEK Leszek: Gimnazjum i Liceum im. Władysława Jagiełły w Krasnymstawie w czasie II-ej wojny światowej. Krasnystaw 2007 Polianna ss. 69, il.

292. JUBILEUSZ częstochowskiego „Sienkiewicza”. Do dr. przygot. Ludomir Olkuśnik. Sowiniec. Nr 30: 2007 s. $13-25$.

Historia Gimnazjum i Liceum im. Henryka Sienkiewicza, od 1862 r.

293. KSIĘGA jubileuszu 40-lecia Liceum Ogólnokształcącego nr VII im. K. K. Baczyńskiego we Wrocławiu. Całość mater. zebr., oprac. i przygot. do dr. Irena Okowiak-Magiera. Wrocław 2007 LO nr VII im. K. K. Baczyńskiego ss. 236, il.

294. OLSZOWSKA Maria: Siostry nazaretanki i ich szkoły w Rabce. Wierchy. R. 71: 2005 [dr.:] 2007 s. 196-197.

Gimnazjum i Liceum Ogólnokształcące (1933-1939), Liceum Administracyjno-Handlowe (1946-1952).

295. PODLASZEWSKA Krystyna: Gimnazjum Toruńskie w latach 1817-1920. Do dr. przygot. Magdalena Niedzielska. Torun 2007 Tow. Nauk.; UMK ss. 223, nlb. 1, il. Tow. Nauk. w Toruniu; UMK w Toruniu.

296. PRZEBOJEM. 100-lecie Gimnazjum i Liceum im. Gen. Jana Henryka Dąbrowskiego w Kutnie 1907-2007. XI Zjazd Absolwentów 23-24 czerwca 2007. Red. odp. Barbara Purgat. Kutno 2007 [B.w.] ss. 112, il.

Rec.: Urbaniak Izabella, Kutn. Zesz. Region. T. 11: 2007 s. 532-534.

297. RACŁAWSKI Kazimierz: Szczęśliwe lata. Gimnazjum i Liceum Ogólnokształcące w Niepokalanowie w latach 1945/1947. Paprotnia 2004 Wydaw. „Perła” ss. 79, nlb. 1, il.

Wspomnienia.

298. RAFIŃSKI Stefan: Z dziejów gimnazjum i liceum ogólnokształcącego w Chełmnie. Wyd. 3, popr. i uzup. Bydgoszcz 2007 Bydgoskie Tow. Nauk. ss. 154, tabl. 10, il., Zsfg.

XIX-XX w.; Wyd. 1. 2001.

299. SAMSONOWSKA Krystyna: I Liceum Ogólnokształcące im. Kazimierza Brodzińskiego w Tarnowie w latach 1939-2000. Tarnów 2006 „S-CAN” Wydaw. ss. 543, nlb. 1, il.

300. [STO] 100 lat Gimnazjum i Liceum im. Marcina Kromera w Gorlicach 1906-2006. Księga pamiątkowa - suplement. Pod red. Renaty Kochan i Stanisława Przybyłowicza; współpr. red. Irena Wierzchołek-Kamińska [i in.]. Tuchów 2006 Mała Poligrafia Redemptorystów ss. 266, nlb. 1, il.

301. [STO] 100 lat historii, 100 lat tradycji. Z dziejów Liceum Ogólnokształcącego im. Tadeusza Kościuszki w Wieluniu w latach 1906-2006. Wieluń 2006 I LO im. Tadeusza Kościuszki ss. 431, nlb. 1, il.

Rec.: Kałwa-Mączyńska Maria, Rocz. Wiel. T. 6: 2006 s. 173-175.

302. SUMA Tomasz: Z kart stuletniej tradycji szkolnej I Liceum Ogólnokształcącego we Wrocławiu. Ludzie i fakty. Dolny Śląsk. Nr 12: 2007 s. 101-108.

Od $1863 \mathrm{r}$.

303. SYRNYK Jarosław: „Szkoła pod specjalnym nadzorem”- inwigilacja IV Liceum Ogólnokształcącego w Legnicy przez komunistyczną Służbę Bezpieczeństwa. W: Ukraińcy w najnowszych dziejach Polski 1918-1989. T. 3. Pod red. Romana Drozda. Słupsk 2007 s. 269-279. 
304. SZKOŁA gostynińska. Sto lat w służbie oświaty 1907-2007. Pod red. Barbary Konarskiej-Pabiniak. Gostynin 2007 Liceum Ogólnokształcące im. Tadeusza Kościuszki ss. 256, il.

305. SZKOŁA na Wiejskiej. Red. Katarzyna Kujawska [i in.]. Wyd. 2 popr. i rozsz. Warszawa 2007 Muzeum Hist. m.st. Warszawy ss. 471, il. (Biblioteka Warszawska).

Pamiętniki z lat 1900-1945 dot. Prywatnego Gimnazjum i Liceum Żeńskie Jadwigi Kowalczykówny i Jadwigi Jawurkówny w Warszawie; Wyd. 1. Kraków 1974.

306. TRUŚCIŃSKI Jerzy: Kultura fizyczna i sport w 100-letniej historii Gimnazjum i Liceum Ogólnokształcącego im. gen. Jana Henryka Dąbrowskiego w Kutnie. Kutno 2007 „Intro-Druk” Barbara i Piotr Żaczek; Społ. Fund. M. Kutna ss. 135, il.

307. Z DZIEJÓW Liceum Ogólnokształcącego im. Kazimierza Wielkiego w Łęczycy. Red. merytoryczna Lucyna Sztompka. Łęczyca-Sierpc 2006 Drukarnia ss. 356, tabl. 1, il. Liceum Ogólnokształcące im. Kazimierza Wielkiego w Łęczycy, Oddz. Tow. Nauk. Płockiego w Łęczycy.

$\mathrm{XX}-\mathrm{XXI}$ w.

Rec.: Szymczak Jan, Rocz. Łódz.. T. 53: 2006 s. 288-290.

308. Z DZIEJÓW I Liceum Ogólnokształcącego. IV wieki kształcenia w Bydgoszczy. Red. nauk. Marian Pawlak. Bydgoszcz 2007 Bydgoskie Tow. Nauk.; Stow. Przyj. I Liceum Ogólnokształcącego C.K.Norwida Jedynka ss. 411, nlb. 1, tabl. 9, il.

Publ. wydana z okazji jubileuszu 130-lecia budynku Szkoły.

\section{Szkoły zawodowe}

309. CHOŁYK Helena: Pod płaszczem Pani i Matki Kijańskiej. Dzieje szkoły w latach 1964 -1969. Lublin [i in.] 2006 Wydaw. Polihymnia ss. 154, tabl. 2, il.

Zespół Szkół Rolniczych w Kijanach.

310. [CZTERDZIEŚCI] 40 lat Zespołu Szkół Technicznych w Lesznie. Zespół red. Piotr Kalitka, Henryk Ratajczyk. Leszno 2005 Zespół Szkół Technicznych ss. 78, il.

311. DĘBOWSKI Grzegorz: Kuźnia charakteryzatorów. Zapomniana szkoła rzadkiej sztuki. Kron. M. Łodzi. 2007 [nr] 3 s. 55-58.

Szkoła Charakteryzacji Artystycznej dla Teatru i Filmu w 1. 1945-1949.

312. DUDA Jerzy, Dzionek Dariusz: Zarys dziejów Zespołu Szkół Mechanicznych w Opolu. Prz. Hist.-Ośw. R. 50: 2007 nr 3 s. 173-178.

Lata $1947-2006$.

313. DUDEK Aleksandra: Materiały do dziejów Szkoły Muzycznej w Gliwicach. Rocz. Muz. Gliw. T. 20: 2006 [dr.:] 2007 s. 501-533, sum., Zsfg.

W 1. 1945-2005.

314. DZIADEK-WILK Józefa: Od szkoły kupieckiej do szkoły ekonomicznej 1897-2007. Księga jubileuszowa z okazji 110 rocznicy powstania Zespołu Szkół Ekonomicznych w Chorzowie. Chorzów 2007 Zespół Szkół Ekonomicznych im. Oskara Langego ss. 72, tabl. 16, sum., rés., Zsfg.

Zespół Szkół Ekonomicznych im. Oskara Langego w Chorzowie.

315. KLEMANTOWICZ Dariusz: Z dziejów szkolnictwa fabrycznego na terenie Łodzi szkoła Ludwika Geyera. Rocz. Łódz. T. 54: 2007 s. 229-242, sum.

XIX-XX w. 
316. MIELCZAREK Andrzej: Korzenie 170-letniej tradycji (zanim „budowlanka” znalazła swój dom w Bronowicach Małych). Bron. Zesz. Hist.-Liter. Z. 20: 2004 s. 30-36.

Zespół Szkół Budowlanych Nr 1 w Krakowie-Bronowicach i jego poprzedniczki.

317. MIELCZAREK A.: Szkoła ze 170-letnią tradycją. Zespół Szkół Budowlanych nr 1 w Bronowicach (1959-2004). Bron. Zesz. Hist.-Liter. Z. 19: 2004 s. 39-45.

318. NOSOWSKI Wiesław: Technikum Chemiczne w Pionkach. Obrazy z przeszłości. Warszawa 2006 Bel Studio ss. 146, il.

W okresie PRL.

319. [OSIEMDZIESIĄT] 80 lat Warszawskiej Szkoły Poligraficznej 1926-2006. Księga jubileuszowa. Pod red. Andrzeja Gierkowskiego; zespół red. A. Gierkowski, Tomasz Pietrzykowski, Andrzej Żurawski. Warszawa 2007 Zespół Szkół Poligraficznych im. Marszałka Józefa Piłsudskiego ss. 436 , il.

320. SALEZJAŃSKA Szkoła Organistowska w Przemyślu i jej likwidacja w roku 1963. Pod red. Roberta Witalca, Igora Witowicza. Rzeszów-Przemyśl 2007 IPN - KŚZpNP. Oddz. w Rzeszowie; Tow. Salezjańskie Dom Zakonny w Przemyślu ss. 308, nlb. 4, tabl. 56, il. IPN - KŚZpNP. Oddz. w Rzeszowie; Tow. Salezjańskie Dom Zakonny w Przemyślu.

Treść: Skałka Kazimierz: Przedmowa s. 11-12; Witalec R., Witowicz I.: Wstęp s. 13-17; Świeży Artur: Powstanie i rozwój Salezjańskiej Szkoły Organistowskiej w Przemyślu w latach 1916-1939 s. 19-49; Żurek Waldemar Witold: Kształcenie organistów w Przemyślu w latach 1946-1963 s. 51-77; Krzysztofiński Mariusz: Likwidacja Szkoły Organistowskiej w 1963 r. Działania aparatu bezpieczeństwa, postawa mieszkańców Przemyśla s. 79-99; Dokumenty. [Z 1. 1916-1965] s. 101-268; Wspomnienia. [Z 1. 50. i 60. XX w., autorstwa: Jana Godlewskiego, Jana Piecucha, Wojciecha Zwierzyńskiego, Jana Sobieskiego, Władysława Szurki, Józefa Herby, Mariana Niedzieli, Antoniego Bylicy, Stanisława Węgrzyna, Jana Pryputniewicza, Zdzisława Majchera, Stefanii Ekiert, Mieczysława Iwaneczki, Ireny i Teodora Kuropatwów, Czesława Rogowskiego] s. 269-296.

321. SAMOLIŃSKI Stefan: Szkoła Rolnicza w Czernichowie k. Krakowa w okresie II wojny światowej 1939-1945. Jej dzieje i losy ludzi z nią związanych. T. 1: Fakty i zdarzenia. Warszawa 2006 Oficyna Wydawnicza Łośgraf ss. 421, il., sum., rés., Zsfg., rez.

Toż. T. 2: Losy życiowe pracowników i wychowanków szkoły. Warszawa 2006 ss. 659, nlb. 2, il.

322. STĘPNIEWSKI Stefan: Historia i teraźniejszość Zespołu Szkół Ekonomicznych w Mińsku Mazowieckim. Mińsk Mazowiecki 2007 Zespół Szkół Ekonom.; Poligrafia Wydaw. ,Żelazo” ss. 349, il.

XX-XXI w.

323. STRAWA Czesław: Z początków szkolnictwa rolniczego na Ziemi Lubuskiej (na przykładzie Państwowego Technikum Rachunkowości Rolnej (PTRR) w Zieleńcu 1948-1963). Nadwarc. Rocz. Hist.-Archiw. Nr 14: 2007 s. 235-265.

324. ŚWISTOWSKI Franciszek: Zamknięta historia chełmskiej szkoły technicznej. Rocz. Chetm. T. 10: 2006 s. 345-372.

Lata $1878-2006$.

325. ZAWISTOWSKI Henryk Jan: Szkoła Żeńska Gospodarstwa Wiejskiego w Nałęczowie w nurcie potrzeb patriotycznych, oświatowych i ekonomicznych wsi polskiej oraz aspiracji programowych Stowarzyszenia Zjednoczonych Ziemianek. W: Ziemiaństwo na Lubelszczyźnie. [Cz. 3]: Panie z dworów i pałaców. Materiały III sesji naukowej zorganizowanej w Muzeum Zamoyskich w Kozłówce, 11-13 października 2006. T. 2. Pod red. Huberta Łaszkiewicza. Lublin 2007 s. 366-401.

326. ZIEMBA Tomasz: Zarys dziejów Zespołu Szkół Zawodowych w Brodnicy. Brodnica 2007 Zespół Szkół Zawodowych ss. 86, nlb. 2, tabl. 4, il.

XX-XXI w. 
327. ŻUREK Waldemar Witold: Salezjańska Szkoła Organistowska w Przemyślu 1915-1963. Arch. Bibl. i Muzea Kośc. T. 86: 2007 s. 379-391, Zsfg.

\section{Zakłady kształcenia nauczycieli (z wyjątkiem szkół wyższych)}

328. CHMIELEWSKI Witold: Licea pedagogiczne - formą kształcenia nauczycieli szkół podstawowych w latach 1944-1956. Prz. Hist.-Ośw. R. 50: 2007 nr 1/2 s. 81-95.

329. KRAJEWSKI Mirosław: Wymyślińska Alma Mater. Seminarium i Liceum Pedagogiczne (1867-1969). Rypin-Wymyślin 2007 Dom Wydawniczy „Verbum” ss. 113, nlb. 3, il.

\section{Szkoły wyższe}

\section{Akademia Górniczo-Hutnicza}

330. CHOCZEWSKI Bogdan: Z dziejów Instytutu Matematyki i Wydziału Matematyki Stosowanej Akademii Górniczo-Hutniczej. Kraków 2007 AGH. Uczelniane Wydaw. Nauk.-Dydaktyczne ss. 164 , tabl. 22, il., sum.

\section{Akademia Marynarki Wojennej}

331. POSIŁA Janusz: Moja droga na morze. Jubileuszowe wspomnienia absolwentów rocznika 1951-1955 oksywskiej Alma Mater. Gdynia 2007 Akad. Marynarki Wojennej im. Bohaterów Westerplatte ss. nlb. 2, 249, nlb. 2, tabl. 98, il.

\section{Akademia Medyczna w Warszawie}

332. KRAWCZYK Marek: Dzieje Wydziału Lekarskiego Akademii Medycznej w Warszawie (1809-2006). Arch. Hist. i Filoz. Med. T. 70: 2007 s. 26-34, streszcz., sum.

\section{Akademia Muzyczna im. Fryderyka Chopina w Warszawie}

333. WASZAK Małgorzata: Karol Szymanowski. Pierwszy rektor Wyższej Szkoły Muzycznej w Warszawie. Warszawa 2007 Wydaw. AM im. F. Chopina ss. 184, il. Akad. Muzyczna im. Fryderyka Chopina w Warszawie. 


\section{Akademia Rolnicza w Szczecinie}

334. PAŁASZ Lech: Rola Akademii Rolniczej w Szczecinie w kształceniu kadr dla rolnictwa. W: Od Państwowych Nieruchomości Ziemskich do restrukturyzacji i prywatyzacji Państwowych Gospodarstw Rolnych na Pomorzu Zachodnim. Materiały z sesji naukowej z 23 czerwca 2006 r. Praca zbior. pod red. Kazimierza Kozłowskiego i Lecha Pałasza. Szczecin 2007 s. 69-81.

\section{Akademia Teatralna im. Aleksandra Zelwerowicza}

335. AKADEMIA Teatralna im. Aleksandra Zelwerowicza. 75 lat kształcenia dla teatru. Kom. red. Magdalena Raszewska [i in.]. Warszawa 2007 Akad. Teatralna im. A. Zelwerowicza ss. 337, nlb. 4, il.

336. [SIEDEMDZIESIĄT pięć] 75 lat kształcenia dla teatru. Akademia Teatralna im. Aleksandra Zelwerowicza. Oprac. red. Marcin Rochowski. Warszawa 2007 Akad. Teatralna im. A. Zelwerowicza ss. 337 , nlb. 3 , il.

\section{Akademia Wychowania Fizycznego we Wrocławiu}

337. TYSZKIEWICZ Jakub: Dzieje Akademii Wychowania Fizycznego we Wrocławiu 1946-2006. Wrocław 2007 Wydaw. AWF ss. 181, nlb. 3, il.

\section{Akademia Wychowania Fizycznego Józefa Piłsudskiego w Warszawie}

338. MY, ABSOLWENCI 1948-1951. Wspomnienia. Red. i oprac. Mieczysław Bilski. Warszawa 2005 Mieczysław Bilski ss. 219. Akad. Wychowania Fizycznego Józefa Piłsudskiego w Warszawie.

\section{Gdańskie Seminarium Duchowne}

339. GDAŃSKIE Seminarium Duchowne 1957-2007. Księga jubileuszowa. Red. Maciej Kwiecień. Gdańsk 2007 Gdańskie Seminarium Duchowne ss. nlb. 4, 234, nlb. 3, il.

Z treści: Rotta Alojzy: Gdańskie Seminarium Duchowne - rys historyczny s. 11-14; Jażdżewski Leszek: Gdańskie Seminarium Duchowne 1957-2000 s. 15-71; Paracki Mirosław: Zaangażowanie biskupa Edmunda Nowickiego w dzieło powołań kapłańskich s. 73-78; Potykanowicz-Suda Lidia: Próby wprowadzenia państwowego nadzoru nad Biskupim Seminarium Duchownym w Gdańsku-Oliwie w świetle akt partyjno-państwowych województwa gdańskiego s. 79-92; Poczet rektorów Gdańskiego Seminarium Duchownego 1957-2007 s. 93-99; Rektorzy Gdańskiego Seminarium Duchownego 1957-2007 s. 101; Wicerektorzy Gdańskiego Seminarium Duchownego 1957-2007 s. 101; Księża profesorowie Gdańskiego Seminarium Duchownego 1957-2007 s. 102-104; Ojcowie duchowni i wykładowcy teologii życia wewnętrznego w Gdańskim Seminarium Duchownym 1957-2007 s. 104-105; Profesorowie świeccy w Gdańskim Seminarium Duchownym 
1957-2007 s. 105; Siostry zakonne ze Zgromadzenia Sióstr Miłosierdzia św. Wincentego à Paulo pracujące w Gdańskim Seminarium Duchownym 1957-2007 s. 106; Pracownicy świeccy Gdańskiego Seminarium Duchownego 1957-2007 s. 107-110; Absolwenci Gdańskiego Seminarium Duchownego 1957-2007 s. 111-118; Zmarli rektorzy, moderatorzy i wykładowcy Gdańskiego Seminarium Duchownego 1957-2007 s. 119-134; Zmarli absolwenci Gdańskiego Seminarium Duchownego 1957-2007 s. 135-152; Wspomnienia absolwentów Gdańskiego Seminarium Duchownego s. 153-189.

\section{Katolicki Uniwersytet Lubelski}

340. INSTYTUT Jana Pawła II KUL. 25 lat działalności. Oprac. red. Danuta WalczewskaBelniak. Lublin 2007 Inst. Jana Pawła II KUL ss. 51, nlb. 1, il.

341. [SZEŚĆDZIESIĘCIOLECIE] 60-lecie Katedry Historii Sztuki Nowożytnej KUL. Rocz. Hum. T. 54: 2006 z. 4 s. 5-65, sum.

Treść: Nieciecki Jan: Katedra Historii Sztuki Nowożytnej Katolickiego Uniwersytetu Lubelskiego Jana Pawła II. Zarys dziejów s. 5-14; Bibliografia prac osób zatrudnionych w Katedrze Historii Sztuki Nowożytnej KUL za lata 1945-2005. (Wybór). Oprac. Irena Rolska-Boruch s. 15-40; Rozprawy doktorskie powstałe w Katedrze Historii Sztuki Nowożytnej KUL w latach 1986-2005. Oprac. I. Rolska-Boruch s. 41; Prace magisterskie powstałe w Katedrze Historii Sztuki Nowożytnej KUL w latach 1946-2006. Oprac. I. Rolska-Boruch s. $42-65$.

342. TEATR, dramat, sacrum. Katedra Dramatu i Teatru KUL (1975-2005). Red. Wojciech Kaczmarek, Anna Podstawka. Lublin 2007 Wydaw. KUL ss. 238, il. KUL Jana Pawła II.

Z treści: Lewko Marian: Tradycje i dzień dzisiejszy Katedry Dramatu i Teatru s. 9-14; Kaczmarek W.: „Post scriptum” do dziejów Katedry s. 15-21; Kaczmarek W.: Irena Sławińska [1913-2004] - erudycja i praca s. 25-55; Staniszewska Maria: Młodzieńcze fascynacje Ireny Sławińskiej s. 57-68; Sawicki Stefan: W kręgu nauki i wiary s. 69-74; Japola Józef: Pani Profesor wobec imponderabiliów s. 75-82; Fert Józef J.: W kręgu Norwida s. 83-86; Sawecka Halina: Romanistka s. 87-93; Strzelecki Ryszard: Ku antropologii teatru s. 103-111; Wójcicki Krzysztof: Teatr i wiara s. 113-119; Ciechowicz Jan: O Irenie Sławińskiej w ogólności s. 121-126; Popowski Remigiusz: Ks. Marian Lewko [1936-2002] - salezjanin s. 129-139; Kaczmarek W.: Teatrolog i literaturoznawca s. 141-148; Podstawka A.: Badacz Strindberga s. 149-156; Strzelecki R.: Krytyk teatralny s. 157-165; Michalczuk Joanna: Mistrz i nauczyciel s. 167-173; Podstawka A.: Księgozbiór Profesora s. 183-189; Inicjatywy badawcze i prace Katedry Dramatu i Teatru w latach 1975-2005 s. 193-238.

343. WOŹNIAKOWSKI Jacek: KUL w PRL. Zesz. Liter. R. 25: 2007 z. 97 s. 131-132. Wspomnienia.

\section{Papieska Akademia Teologiczna}

344. KUBIŚ Adam: Dramatyczne początki Papieskiej Akademii Teologicznej w Krakowie. Analecta Cracoviensia. [T.] 38/39: 2006/2007 [dr.:] 2007 s. 1-73, Zsfg.

Lata 1971-1983.

345. ŻUREK Antoni: Geneza i historia powstania Wydziału Teologicznego sekcja w Tarnowie Papieskiej Akademii Teologicznej w Krakowie. Tarn. Studia Teol. T. 26: 2007 s. 157-160.

Lata 1945-2004. 


\section{Politechnika Krakowska}

346. FOROWICZ Jan: Wolne Radio Nowinki. Wspomnienia ze studiów w Politechnice Krakowskiej. Kraków-Warszawa 2007 Jan Forowicz ss. 32, il.

Lata 1959-1963.

\section{Politechnika Świętokrzyska}

347. ADAMCZAK Stanisław, Lubecki Paweł: 40 lat Wydziału Mechatroniki i budowy Maszyn Politechniki Świętokrzyskiej w Kielcach dawnego Wydziału Mechanicznego 1965-2005. Kielce 2005 Politech. Świętokrzyska ss. 194, il.

\section{Seminarium Duchowne we Wrocławiu}

348. HANC Wojciech: Nauczanie teologii dogmatycznej we włocławskim Seminarium Duchownym po II wojnie światowej. Studia Włocławskie. T. 10: 2007 s. 366-401.

\section{Śląski Uniwersytet Medyczny}

349. SŁOWNIK medycyny i farmacji Górnego Śląska. T. 6: Monograficzny: Śląski Uniwersytet Medyczny w 60-lecie Śląskiej Akademii Medycznej. Pod red. Władysława Pierzchały. Katowice 2007 ŚUM. BG ss. 234, nlb. 6, il. Śląski Uniw. Medyczny w Katowicach. Bibl. Gł.

T. 1. 1993.

\section{Uniwersytet Gdański}

350. [CZTERDZIEŚCI] 40 lat oceanografii na Uniwersytecie Gdańskim. Historia, wspomnienia, fakty. Zebrał, zestawił i komentarzem opatrzył Marcin Pliński. Gdańsk-Sopot 2007 Wydaw. Uniw. Gdańskiego ss. 396, nlb. 1, il.

\section{Uniwersytet Jagielloński}

351. BASTER Marcin: Rola dochodów żupnych i nadań solnych w funkcjonowaniu uniwersytetu krakowskiego. Studia i Materiaty do Dziejów Żup Solnych w Polsce. T. 25: 2007 s. 93-102, sum.

XIV-XVIII w. 
352. BŁOŃSKA Diana: Studium Kolonialne Uniwersytetu Jagiellońskiego. Zesz. Nauk. UJ. [Nr] 1291. Prace Hist. Z. 134: 2007 s. 91-103, sum.

Lata $1937-1939$.

353. OKOŃ Jan: Z dziejów teatru Akademii Krakowskiej epoki Wazów - jubileuszowo (historia, folklor i fikcja na scenie szkolnej 1637 roku). W: Rzeczy minionych pamięć. Studia dedykowane profesorowi Tadeuszowi Ulewiczowi w 90. rocznicę urodzin. Pod red. Andrzeja Borowskiego i Jakuba Niedźwiedzia. Kraków 2007 s. 385-402.

\section{Uniwersytet Lwowski}

354. CIARA Stefan: Nauki pomocnicze historii na Uniwersytecie Jana Kazimierza we Lwowie w dobie II Rzeczypospolitej. W: Wielokulturowe środowisko historyczne Lwowa w XIX i XX w. T. 5. Pod red. Jerzego Maternickiego, Leonida Zaszkilniaka. Rzeszów 2007 s. 395-408.

355. DRAUS Jan: Uniwersytet Jana Kazimierza we Lwowie 1918-1946. Portret kresowej uczelni. Kraków 2007 Księg. Akademicka ss. 328, nlb. 8, il.

356. PODRAZA Antoni: Studenci historii na Uniwersytecie Lwowskim w latach II wojny światowej (ze wspomnień własnych). W: Studia Lodomeriana. Historia, kultura, prawo. Pod red. Karoliny Grodziskiej i Grzegorza Niecia. Kraków 2007 s. 153-162.

357. SYTNYK Ołeksandr: Katedry archeologii Uniwersytetu Lwowskiego w latach 1905-2005. Prz. Archeol. T. 54: 2006 s. 125-159, abstr., sum.

\section{Uniwersytet Łódzki}

358. CZERWIŃSKA Jadwiga, Danek Zbigniew, Zalewska-Jura Hanna: Filologia klasyczna Uniwersytetu Łódzkiego - wielcy badacze, niezapomniane osobowości. Acta UL. Folia Litteraria Polonica. [Vol.] 9: 2007 s. 371-378.

359. GAJOS Mieczysław: Z kart historii Katedry Filologii Romańskiej Uniwersytetu Łódzkiego. Acta UL. Folia Litteraria Polonica. [Vol.] 9: 2007 s. 347-352.

Od 1945 r.

360. KRYPTONIM „Heca”. Red. Włodzimierz Domagalski; przy współpr. Adama Hohendorffa, Wiesława Maciejewskiego, Piotra Wojtczaka. Łódź 2006 NZS Regionu Łódzkiego ss. 136, il. Niezależne Zrzeszenie Studentów, Stow. Niezależni RP.

Antologia wspomnień o pacyfikacji strajku studentów na Wydziale Prawa Uniw. Łódzkiego w 1981 r. Rec.: Śreniowski Józef: Relacja ustna na wiele głosów. Kron. M. Łodzi. 2007 [nr] 1 s. 245-251.

361. OSTROWSKI Marek: Szkice z historii germanistyki na Uniwersytecie Łódzkim. Acta UL. Folia Litteraria Polonica. [Vol.] 9: 2007 s. 359-363.

Od 1945 r.

362. TADEUSIEWICZ Hanna: Katedra Bibliotekoznawstwa i Informacji Naukowej (1945-2007). Acta UL. Folia Litteraria Polonica. [Vol.] 9: 2007 s. 327-331. 


\section{Uniwersytet Marii Curie-Skłodowskiej}

363. DOMAŃSKI Cezary W.: Chlubne tradycje. Początki psychologii na Uniwersytecie Marii Curie-Skłodowskiej. Annales UMCS. Sec. J: Paedagogia - Psychologia. Vol. 20: 2007 s. 13-21, sum.

Lata 1944-1949.

364. WÓJCIUK Michał: Koło Naukowe Historyków Studentów UMSC w Lublinie (1953-2001). Działalność studenckiej organizacji naukowej na tle przemian społecznych i ustrojowych w Polsce. Radz. Rocz. Hum. T. 5: 2007 s. 190-215.

365. WYDZIAŁ Ekonomiczny Uniwersytetu Marii Curie-Skłodowskiej w Lublinie 19652005. Księga jubileuszowa. Oprac. i red. Józef Duda, Zdzisław Szymański, Jerzy Węcławski. Lublin 2005 Wydaw. UMCS ss. 479, il.

\section{Uniwersytet Mikołaja Kopernika}

366. DZIAŁALNOŚĆ naukowa i dydaktyczna Zakładu Klimatologii Instytutu Geografii UMK w latach 1947-2007. Red. i przygot. do dr. Rajmund Przybylak, Marek Kejna, Kazimierz Marciniak. Torun 2007 Wydaw. UMK ss. 165, nlb. 2, il. UMK. Wydz. Biologii i Nauk o Ziemi.

367. GOMOLISZEK Joanna: Periodyki studentów Wydziału Nauk Historycznych Uniwersytetu Mikołaja Kopernika w Toruniu. Folia Toruniensia. [T.] 6: 2006 s. 57-71.

Od $1993 \mathrm{r}$.

\section{Uniwersytet Opolski}

368. [PIĘĆDZIESIĄT] 50 lat Wydziału Filologicznego Uniwersytetu Opolskiego. Księga jubileuszowa. Pod red. Mieczysława Balowskiego i Stanisława Kochmana. Opole 2005 Wydaw. Uniw. Opolskiego ss. 124, tabl. 28, il. Uniw. Opolski. Wydz. Filologiczny.

Z treści: Kochman S.: Wydział Filologiczny Uniwersytetu Opolskiego - początki i stan obecny s. 23-27; Piasecki Zdzisław: Literaturoznawstwo opolskie w okresie ostatniego półwiecza s. 29-48; Pluta Feliks: Językoznawstwo opolskie w okresie ostatniego półwiecza s. 49-64; Simonides Dorota: Folklorystyka opolskie w okresie ostatniego półwiecza s. 65-75; Balowski M.: Wydział Filologiczny Uniwersytetu Opolskiego w latach $2002-2005$ s. 77-118.

\section{Uniwersytet Szczeciński}

369. KOŹMIAN Danuta: Studenci Uniwersytetu Szczecińskiego i ich organizacje w latach 1985-2000. Szczecin 2007 Wydaw. Nauk. Uniw. Szczecińskiego ss. 185, il. Uniw. Szczeciński. (Rozprawy i Studia; t. 660 (734)). 


\section{Uniwersytet Śląski}

370. ZWIĄZEK Jan: Sprawozdanie z działalności Podyplomowych Studiów Archiwistyki Kościelnej na Wydziale Teologicznym Uniwersytetu Śląskiego w latach 2005-2006. Śl. Studia Hist.-Teol. T. 39: 2006 z. 2 s. 504-507.

\section{Uniwersytet Warszawski}

371. KSIĘGA pamiątkowa absolwentów Wydziału Geologii 1952-2007. Red. Wojciech Salski. Warszawa 2007 Stow. Absolwentów Wydz. Geologii Uniw. Warszawskiego ss. 194, nlb. 1, il. Stow. Absolwentów Wydz. Geologii Uniw. Warszawskiego.

Antologia wspomnień.

372. MIZIOŁEK Jerzy, Baliszewski Mikołaj: Educatio te ars. Zbiory artystyczne pierwszego Uniwersytetu Warszawskiego i ich rola w muzeologii warszawskiej. W: 200 lat muzealnictwa warszawskiego - dzieje i perspektywy. Materiały sesji naukowej, Zamek Królewski w Warszawie 16-17 listopada 2005 roku. Kom. red. Andrzej Rottermund, Andrzej Sołtan, Marek Wrede. Warszawa 2006 s. 217-233.

373. NA CHWAŁĘ i pożytek nasz wzajemny. Złoty jubileusz Polonicum. Kom. red. Ewa Rohozińska, Marta Skura, Anna Piasecka. Warszawa 2006 Wydaw. Uniw. Warszawskiego ss. 365, tabl. 24. Centrum Języka Pol. i Kultury Pol. dla Cudzoziemców Polonicum.

Centrum Języka Polskiego i Kultury Polskiej dla Cudzoziemców Polonicum Uniwersytetu Warszawskiego.

Z treści: Dubisz Stanisław: Do czego glottodydaktyka jest potrzebna? Tytułem wprowadzenia - na 50-lecie Polonicum s. 15-18; Kacprzak Lidia: Polonicum Uniwersytetu Warszawskiego s. 21-32; Jekiel Wojciech: Pierwsze lata s. 43-51; Kacprzak L.: Polonicum - od serca i „od podszewki” s. 53-63; Wrocławski Krzysztof: Polonicum w moich wspomnieniach (lata 1965-1978) s. 73-85; Teklińska-Kotulska Eulalia: Pierwsze kroki w Polonicum s. 87-90; Red.: Kształcenie lektorów s. 115-118; Frybes Stanisław: Irena Quirini. Wspomnienie (1914-1998) s. 119-120; Masłowski Michał: Pojęcie „kanon kultury” w nauczaniu historii i literatury polskiej za granicą s. 195-199; Mirkulovska Milica: Macedońsko-polskie i polsko-macedońskie kontakty w dziedzinie językoznawstwa s. 209-215; Molnár István D.: O związkach polskiego i węgierskiego kalwinizmu (do 2001 roku) s. 241-253; Trepte Hans-Christian: Endstation Deutschland? - Stacja końcowa Niemcy? Czyli „Anioły i świnie (nie tylko) w Berlinie" s. 275-282; Masi Leonardo: STS, Bim-Bom, Piwnica pod Baranami: trzy strategie satyryczne w latach odwilży s. 283-289; Sękowska Elżbieta: Historyczno-kulturowy aspekt frazeologii s. 303-309; Ananiewa Natalia E.: O Polonicum i polonikach słów kilka s. 311-316.

374. [SIEDEMDZIESIĄT pięć] 75 lat Instytutu Orientalistycznego Uniwersytetu Warszawskiego. Praca zbiorowa. Pod red. nauk. Macieja Popko. Warszawa 2007 Wydaw. Uniw. Warszawskiego ss. 179 , nlb. 1.

Treść: Popko M.: Z dziejów Instytutu Orientalistycznego UW s. 9-22; Piłaszewicz Stanisław: Afrykanistyka s. 23-36; Kopp Edyta: Egiptologia s. 37-42; Sandowicz Małgorzata: Asyriologia s. 43-51; Taracha Piotr: Hetytologia s. 53-62; Tomal Maciej: Hebraistyka s. 63-72; Dziekan Marek M.: Arabistyka i Islamistyka s. 73-81; Nalborczyk Agata S.: Zakład Islamu Europejskiego s. 83-88; Malicki Jan: Studium Europy Wschodniej s. 89-94; Majda Tadeusz: Studia turkologiczne (1983-2006) s. 95-100; Sierakowska-Dyndo Jolanta, Surdykowska Sylwia: Iranistyka s. 101-109; Mejor Marek: Studia sanskrytologiczne i buddologia s. 111-121; Stasik Danuta: Studia nad językiem i literaturą hindi s. 123-131; Walter Elżbieta: Bengalistyka s. 133-139; Kusio Joanna: Studia drawidyjskie s. 141-155; Bareja-Starzyńska Agata: Mongolistyka i tybetologia s. 147-156; Kțnstler M. Jerzy: Sinologia s. 157-162; Rurarz Joanna P.: Koreanistyka s. 163-169; ŻuławskaUmeda Agnieszka: Japonistyka s. 171-179. 
375. SIKORSKI Robert: Szczególna Szkoła Leśnictwa 1818-1832. Ciech. Rocz. Muz. T. 3: 2007 s. $97-102$.

376. SOCJOLOGIA na Uniwersytecie Warszawskim. Fragmenty historii. Zebr., oprac. i w całość ułożył Antoni Sułek. Warszawa 2007 Wydaw. IFiS PAN ss. 543. Inst. Socjologii Uniw. Warszawskiego.

Treść: Sułek A.: Idea i treść tomu s. 9-14; Szacki Jerzy: Środowisko socjologów warszawskich s. 15-28; Szyszkowski Wacław: Na wykładach Petrażyckiego i Krzywickiego s. 56-59; Sułek Róża: Droga Stefana Czarnowskiego do katedry socjologii w Uniwersytecie Warszawskim s. 63-96; Ossowski Stanisław: Stefan Czarnowski (1879-1937) s. 97-100; Gerber Rafał: Ankieta Koła Socjologii Pozytywnej S.U.J.P. o warunkach życia młodzieży akademickiej w Polsce s. 101-104; Bartoszewski Władysław: Tajny komplet na Żoliborzu. Tragiczna karta z dziejów nauki podziemnej s. 119-122; Kraśko Nina: Ramy instytucjonalne socjologii na Uniwersytecie Warszawskim 1946-1956 s. 125-137; Nowakowski Stefan: Badania Zakładu Socjologii UW. Stanisław Ossowski jako badacz terenowy s. 138-147; Ossowski Stanisław: Uwagi o prowadzeniu seminarium dla studentów na Wydziale Filozoficzno-Społecznym s. 157-167; Sarapata Adam: Z pracy Zakładu Materializmu Historycznego UW s. 168-172; Prace magisterskie z socjologii na Uniwersytecie Warszawskim, 1949-1957 s. 177-184; Katedry socjologiczne na Uniwersytecie Warszawskim S. 208-217; Sułek A.: Fata i fatum „Studentów Warszawy" s. 229-238; Raciborski Jacek: Marksizm w warszawskiej socjologii uniwersyteckiej. Rozkwit i zmierzch s. 239-260; Karpiński Jakub: Na Uniwersytecie s. 261-274; Hirszowicz Maria: Socjologia na Wydziale Filozoficznym UW w latach sześćdziesiątych s. 275-283; Akcja i reakcja: dokumenty z marca 1968 roku s. 294-305; Instytut Socjologii wobec Solidarności s. 323-334; W Instytucie Socjologii s. 337-399; Wspomnienia s. 403-496; Aneksy s. 499-526.

\section{Uniwersytet Wrocławski}

377. ALECHNOWICZ Iwona: Filozofia na Uniwersytecie Wrocławskim w latach 1895-1935. Opole 2007 Wydaw. Uniw. Opolskiego ss. 231, Zsfg. Uniw. Opolski. (Studia i Monografie; nr 384).

378. CZAPLIŃSKI Marek: Wolność, obiektywizm, niezależność poglądów profesorów Uniwersytetu Wrocławskiego w XIX wieku. Studium wybranych przykładów. W: Tempus nostrum est. Księga pamiątkowa ofiarowana profesorowi Edwardowi Włodarczykowi w 60. rocznicę urodzin. Pod red. Włodzimierza Stępińskiego, Dariusza Szudry, Ryszarda Techmana. Szczecin 2006 s. $427-442$.

379. CZAPLIŃSKI M.: Wydział Filozoficzno-Historyczny, potem Wydział Nauk Historycznych i Pedagogicznych, w latach 1970-1994. W: Między Lwowem a Wrocławiem. Księga jubileuszowa profesora Krystyna Matwijowskiego. Pod red. Bogdana Roka i Jerzego Maronia. Toruń 2006 s. $1019-1030$.

380. KOREDCZUK Józef: 60-lecie powołania katedr historyczno-prawnych na Wydziale Prawa Uniwersytetu Wrocławskiego. Acta Univ. Wr. No 3015: Prawo. [T.] 303: Studia historycznoprawne: 2007 s. 9-73, Zsfg.

381. KOREDCZUK J.: Wspomnienia i plotki, czyli o tych, co odeszli, lecz w pamięci pozostali. Acta Univ. Wr. No 3015: Prawo. [T.] 303: Studia historycznoprawne: 2007 s. 75-101, Zsfg.

Osoby związane z Zespołem Katedr Historyczno-Prawnych Uniwersytetu Wrocławskiego.

382. KOZUSCHEK Waldemar: Rozwój anatomii patologicznej na Uniwersytecie Wrocławskim oraz w Akademii Medycznej we Wrocławiu wraz z zarysem historycznym przedmiotu. Die Entwicklung der pathologischen Anatomie der Universität Breslau sowie der Medizinischen Aka- 
demie Wrocław zugleich ein Rückblich in die Geschichte des Faches. Wrocław 2007 Wydaw. Uniw. Wrocławskiego ss. 337, nlb. 3, il., sum. (Acta Universitatis Wratislaviensis; no 2932).

Tekst równol. pol., niem.

Rec.: Janiuk Jerzy, Medycyna Nowożytna. R. 8: 2007 z. 1/2 s. 175-178; Ostrowska Teresa, Kw. Hist. Nauki i Techn. R. 52: $2007 \mathrm{nr}$ 3/4 s. 329-331.

383. NOWAK Konrad: Grundniss der Geschichte er Rechtswissenschaften an der Universität Breslau. Übers. von Ewa Perucka-Szczygieł, Tomasz Milej. Wrocław 2007 Wydaw. Uniw. Wrocławskiego ss. 219, nlb. 2, il. (Acta Universitatis Wratislaviensis; no 2989).

Tyt. oryg.: Zarys dziejów prawa na Uniwersytecie Wrocławskim.

XVIII-XX w.

384. [TRZYDZIESTOPIĘCIOLECIE] 35-lecie Instytutu Nauk Administracyjnych Uniwersytetu Wrocławskiego. Pod red. Jana Bocia. Wrocław 2007 Kolonia Limited ss. 158, il.

Mater. posiedzenia nauk., 29 XI 2005 r.

\section{Uniwersytet Zielonogórski}

385. SZCZEGÓŁA Hieronim: Zielonogórska droga do uniwersytetu. (Cz. 1). Studia Ziel-Górs. T. 13: 2007 s. $127-146$.

XX-XXI w.

Wyższa Szkoła Handlowa we Wrocławiu

386. STRASZAK-CHANDOHA Sylwia: Pochodzenie terytorialne i środowiskowe pierwszych studentów WSH w latach 1947-1950. W: Gospodarka i społeczeństwo w czasach PRL-u (1944-1989). Wrocławskie Spotkania z Historią Gospodarczą, spotkanie 2. Pod red. Elżbiety Kościk i Tomasza Głowińskiego. Wrocław 2007 s. 274-285.

\section{Wyższa Szkoła Rozwoju Lokalnego}

387. GAŁĄZKA Ewa, Rakowski Witold: Wyższa Szkoła Rozwoju Lokalnego i jej działalność w latach 1997-2004. Rocz. Żyr. T. 4: 2006 s. 477-485.

\section{Wyższe Seminarium Duchowne w Pińsku}

388. WIERNA Renata: Nauczanie teologii moralnej w Wyższym Seminarium Duchownym w Pińsku w latach 1926-1939. Studia Teol. [T.] 24: 2006 s. 343-349. 


\section{BIOGRAFIE}

\section{Zbiory życiorysów}

389. BIOGRAFIE nauczycieli zasłużonych dla oświaty i środowiska regionu puławskiego. T. 1. Oprac. red. Stanisław Jednacz, Danuta Kaliszczuk. Puławy 2002 Tow. Przyj. Muzeum Oświatowego ss. 147, nlb. 2, il.

Toż. T. 2. Puławy 2004 ss. 160, il.; Toż. T. 3. Kom. red. Sławomir Pać [i in.]. Puławy 2007 ss. 94, il.

XIX-XX w.

390. FEITEK Alojzy: Zasłużeni nauczyciele gminy Stara Kiszewa. Okres za lata 1918-1939 i od 1945 roku do chwili obecnej. Ziemia Gdańska. R. 5: 2006 s. 129-134.

391. GLIMOS-NADGÓRSKA Anna: Nauczyciele w powstaniach śląskich. Materiały biograficzne. W: W 85. rocznicę. Red. nauk. Zbigniew Kapała. Bytom 2007 s. 172-179.

392. KALISZUK Tomasz: Miejsca pamięci narodowej w Białej Podlaskiej poświęcone walce narodowo-wyzwoleńczej i martyrologii. Cz. 2: Tablice pamiątkowe poświęcone bialskim nauczycielom poległym i zamordowanym w okresie II wojny światowej i zmarłym w latach powojennych. Rocz. Bial.-Podl. T. 14: 2006 s. 145-191.

Cz. 1. Tamże. T. 12: 2004.

393. KĘTRZYN - oni tworzyli historię. Życiorysy mieszkańców. Praca zbiorowa. Red. Lucyna Tokarczyk, Maria Rutkowska-Kupran. Olsztyn-Kętrzyn 2007 Studio „Antykwa”; staraniem Tow. Miłośn. Kętrzyna ss. 191, il.

$\mathrm{Z}$ treści: Oświata s. $79-122$.

394. KORZENIOWSKA Wiesława: Słownik biograficzny historii myśli pedagogicznej. Bielsko-Biała 2006 Wyższa Szkoła Administracji ss. 148. Wyższa Szkoła Administracji w Bielsku-Białej. Wydz. Nauk Społecznych.

395. KOWALSKI Wiesław: Przedwojenni nauczyciele Łodzi. Wspomnienia i refleksje. Łódź 2007 Drukarnia Cyfrowa i Wydaw. „Piktor” ss. 81, il. (Łódź i Łodzianie).

Słownik, XIX-XX w.

396. KUPISIEWICZ Czesław, Kupisiewicz Małgorzata: Poczet wybitnych nauczycieli. Pułtusk 2006 Akad. Hum. im. Aleksandra Gieysztora; „Głos Nauczycielski” ss. 199, nlb. 1, il. (Biblioteka „Artes Liberale"; 1-2).

Toż. Cz. 2. Pułtusk 2007 ss. 222, il.

397. LEKSYKON profesorów Akademii Pedagogicznej im. Komisji Edukacji Narodowej 1946-2006. Pod red. Józefa Hampla, Feliksa Kiryka, Iwony Pietrzkiewicz. Kraków 2006 Wydaw. Nauk. Akad. Pedag. ss. 660, il.

W Krakowie.

398. PEST Czesław: Rektorzy Seminarium Duchownego w Gnieźnie 1602-2005. Gniezno 2005 Prymasowskie Wyższe Seminarium Duchowne ss. 219, nlb. 1, tabl. 24, il.

399. POCZET rektorów Wyższej Szkoły Handlowej, Wyższej Szkoły Ekonomicznej i Akademii Ekonomicznej we Wrocławiu 1947-2007. Pod red. Józefa M. Soroki. Wrocław 2007 Wydaw. Akad. Ekonomicznej im. Oskara Langego ss. 228, nlb. 1.

Treść: Fiedor Bogusław: Słowo wstępne JM Rektora s. 7-8; Straszak-Chandocha Sylwia: Kamil Ignacy Stefko 1947-1951 s. 9-25; Sobczak Mieczysław: Stefan Górniak 1951-1952 s. 27-46; Sobczak M.: Antoni 
Wrzosek 1952-1955 s. 47-63; Soroka J. M.: Krzysztof Jeżowski 1955-1956 s. 65-77; Jasiński Jan: Wincenty Styś 1956-1959 s. 79-119; Kocowski Tadeusz: Adam Chełmoński 1959 s. 121-137; Śmieja Andrzej: Józef Fiema 1959-1966 s. 139-151; Linek Stefan: Józef Popkiewicz 1966-1979 s. 153-164; Bogacka-Kisiel Ewa: Józef Kaleta 1979-1987, 1990-1993 s. 165-173; Ryszawska-Grzeszczak Bożena: Wiesław Pluta 1987-1990 s. 175-187; Owoc Mieczysław Lech: Andrzej Baborski 1993-1999 s. 189-202; Sawicka Magdalena: Marian Noga 1999-2005 s. 203-213; Graczyk Andrzej: Bogusław Fiedor 2005- s. 215-229.

400. POLSKA myśl pedagogiczna po 1918 roku. Praca zbior. pod red. Ewy Brodackiej-Adamowicz. Wyd. 2 uzup. i rozsz. Siedlce 2007 Wydaw. Akad. Podlaskiej ss. 197.

Słownik biograficzny; Wyd. 1. 2001.

401. [PROFESOROWIE Politechniki Łódzkiej. Biogramy]. Zesz. Hist. Politech. Łódz. Z. 5: 2007 s. $7-164$.

402. PROFESOROWIE prawa Katolickiego Uniwersytetu Lubelskiego. Pod red. Antoniego Dębińskiego, Wojciecha S[zczepana] Staszewskiego, Moniki Wójcik. Lublin 2006 Wydaw. KUL ss. 336.

Rec.: Olszewski Henryk, Czasop. Prawno-Hist. T. 59: 2007 z. 1 s. 350-353.

\title{
2. Poszczególne biografie
}

\author{
Bronisław Markiewicz, bł.
}

403. WOLICKI Marian: Błogosławiony ks. Bronisław Markiewicz (1842-1912) jako promotor wychowania i nauczania młodzieży na Podkarpaciu. Premislia Christiana. T. 12: 2006/2007 [dr.:] 2007 s. 193-208, Zsfg.

\section{Dobrowolski Antoni Bolesław}

404. GLISZCZYŃSKA Halina: Antoni Bolesław Dobrowolski [1872-1954] jako teoretyk organizacji szkolnictwa. Wrocław 2007 Wydaw. Mar-Mar Marian Kaczorowski ss. 71.

\section{Domagała Ludwik}

405. KSIĄŻEK Jan: Ludwik Domagała [1880-1951] - pedagog, działacz społeczny i polityczny. Rocz. Wiel. T. 6: 2006 s. 81-98.

\section{Frycie Stanisław}

406. BANACH Czesław: Profesor Stanisław Frycie [ur. 1933] jako pedagog i organizator prac nad treściami kształcenia ogólnego w latach 1976-1990. W: W kręgu literatury i języka. Praca zbior. pod red. Anny Grochulskiej. Piotrków Trybunalski 2005 s. 539-544. 


\section{Jarzębowski Wojciech Bogumił}

407. SIKORSKI Robert: Wojciech Bogumił Jarzębowski (1799-1882) przyrodnik, pedagog, wizjoner zjednoczonej Europy. Ciech. Rocz. Muz. T. 1: 2005 s. 199-205.

\section{Karbowiak Antoni}

408. WAŁĘGA Agnieszka: Antoni Karbowiak (1856-1919) - współtwórca polskiej historii wychowania jako dyscypliny naukowej. Biul. Hist. Wychowania. 2005/2006 [dr.:] 2007 [nr] 1/2 s. $11-24$.

\section{Klepacz Michał}

409. WIECZOREK Edward: Działalność pedagogiczna biskupa Michała Klepacza [18931967]. Łódź 2007 Archidiec. Wydaw. Łódzkie ss. 175, il. (Z Dziejów Kościoła Łódzkiego).

\section{Kołakowski Jerzy, Kołakowski Leszek}

410. KOŁAKOWSCY w Radomiu. Ojciec i syn. Oprac. wyd. Marcin Olifirowicz [i in]. Radom 2007 Wydaw. Inst. Technologii Eksploatacji - PIB ss. 105, tabl. 14, il.

Treść: Chudoba Wiesław: Wprowadzenie do spółdzielczych koncepcji Jerzego Kołakowskiego (Jerzego Karona) [1894-1943] s. 9-23; Karon Jerzy: Działalność kulturalno-oświatowa na terenie miasta Radomia. [Podtyt.: Monografia społeczna. Reprint: Radom 1930 Druk. S. Nowakowski ss. 56] s. 25-79; Chudoba W.: Szkolne lata Leszka Kołakowskiego [ur. 1927] z Radomiem w tle s. 81-88; Kołakowski Leszek: Cywilizacja na ławie oskarżonych s. 89-97; Żytnicki Dariusz: Mikrohistoria XX wieku, czyli słów kilka o dziejach II Liceum Ogólnokształcącego im. Marii Konopnickiej w Radomiu w latach 1902-2006 s. 99-106.

\section{Kołłątaj Hugo}

411. BUCZEK Katarzyna: Hugo Kołłątaj i edukacja. Warszawa 2007 Wydawnictwa Uniw. Warszawskiego ss. 194, nlb. 2, tabl. 4.

\section{Komeński Jan Amos}

412. DANCÁK Pavol: Sens wychowania w zamyśle Jana Amosa Komeńskiego. W: Cnoty i wady. Społeczeństwo baroku po obu stronach Karpat. Pod red. J[ózefa] Mareckiego i L[ucyny] Rotter. Kraków 2007 s. 197-207. 


\section{Korczak Janusz}

413. KORCZAK i jego dzieło. Red. Maria Grażyna Szpyra, Zuzanna Orlińska. Krasnobród 2006 Samodzielne Publiczne Sanatorium Rehabilitacyjne dla Dzieci im. Janusza Korczaka w Krasnobrodzie ss. 72 , il.

Katalog wystawy.

\section{Krasuski Józef}

414. MAJEWSKI Stanisław: Józef Krasuski [ur. 1933] - historyk wychowania i nauczyciel akademicki. Prz. Hist.-Ośw. R. 50: 2007 nr 3 s. 193-196.

\section{Majewski Stanisław}

415. PLUTA Leonard: Stanisław Majewski [1878-1955] koordynator i organizator średniego szkolnictwa dozoru górniczego w Polsce (1924-1939 i 1945-1948). Katowice 2007 Muzeum Śląskie ss. 18, il. (Wszechnica Muzeum Śląskiego).

\section{Malec Stanisław}

416. WASIAK Marek: Stanisław Malec (1895-1943) i jego dorobek dydaktyczny. Prz. Hist.-Ośw. R. 50: 2007 nr 1/2 s. 205-216.

\section{Marcelina Darowska, bł.}

417. MAJEWSKA Marta: Program pedagogiczny Matki Marceliny. W: Bł. Marcelina Darowska [1827-1911] - dar na trzecie tysiąclecie. Ogólnopolska sesja naukowa z okazji dziesięciolecia beatyfikacji, Szymanów, 23 IX 2006. Red. Marek Chmielewski, Janina Martynuska. Lublin-Szymanów 2007 s. 89-108.

\section{Michalski Ryszard}

418. GULCZYŃSKI Janusz: Ryszard Michalski [1905-1985] - nauczyciel, publicysta, malarz regionalny. Rocz. Konin. T. 16: 2007 s. 235-244. 


\section{Podgórska Eugenia}

419. WITKOWSKA-URBAN Ewa: Eugenia Podgórska (1914-2006). Prz. Hist.-Ośw. R. 50: 2007 nr 3 s. $185-188$.

\section{Rogaliński Józef}

420. CHŁAPOWSKI Franciszek: Józef Rogaliński [1728-1802] - uczony poznański czasów Oświecenia. Fizyk, astronom, pedagog. Komentarze Hieronim Hurnik, Wojciech Szczęsny Kaczmarek; posł. Jacek Wiesiołowski. Wyd. 2 uzup. Poznań 2007 Wydaw. Miej. ss. nlb. 2, XI, nlb. 1, 177, nlb. 3, il. (Biblioteka „Kroniki Miasta Poznania”) (Wznowienia).

Wyd. 1. Cz. 1-2. Poznań 1902-1905.

\section{Ruta Zygmunt}

421. GAWLIK Stanisław: Z „małej ojczyzny” do grodu Kraka. Biul. Hist. Wychowania. 2005/2006 [nr] 1/2 [dr.:] 2007 s. 121-124.

Profesor Zygmunt Ruta z okazji 75-lecia urodzin.

422. GAWLIK S., Jakubiak Krzysztof: 75-lecie urodzin Profesora zwyczajnego Zygmunta Ruty. Biul. Hist. Wychowania. 2005/2006 [nr] 1/2 [dr.:] 2007 s. 115-120.

\section{Sikorski Walerian}

423. TOMIK Rajmund: Działalność Waleriana Sikorskiego (1876-1940) w zakresie wychowania fizycznego i sportu szkolnego. Katowice 2006 Wydaw. Akad. Wychowania Fizycznego ss. 109, il. Akad. Wychowania Fizycznego w Katowicach.

\section{Still Johann}

424. KONTRIKOVÁ Iveta, Kontrik Jozef: Johann Still [1805-1890], nauczyciel i przewodnik górski. Wierchy. R. 71: 2005 [dr.:] 2007 s. 208-213.

\section{Stonawski Jerzy}

425. KRÓL Józef: Pierwszy dyrektor pierwszej polskiej szkoły. Kalendarz Cieszyński. [R. 24]: 2008 [dr.:] 2007 s. $133-139$.

Jerzy Stonawski (1883-1936), dyrektor Państwowej Szkoły Przemysłowej w Bielsku. 


\section{Strzałkowska Zofia}

426. SANOJCA Karol: Ideały wychowawcze Zofii Strzałkowskiej (1861-1923). W: Między Lwowem a Wrocławiem. Księga jubileuszowa profesora Krystyna Matwijowskiego. Pod red. Bogdana Roka i Jerzego Maronia. Toruń 2006 Adam Marszałek s. 887-894.

\section{Tatar Antonina}

427. ANTONINA Tatar [1899-1958]. Człowiek - pedagog. Oprac. i red. Krystyna Zabrzewska, Barbara Jurak. Suche-Kraków 2003 Szkoła Podstawowa; Wydaw. „Gotów” Katolickiego Stow. Młodzieży ss. 40, nlb. 8, il.

Treść: Wspomnienia: Tatar Stanisław: Moja siostra s. 5-10; Jędrol Józef: O ciotce s. 11-14; Świżek Władysław: Z pamiętnika księdza s. 15; Wywiady s. 17-30; Przegląd prasy - „Gazeta Podhalańska” (1922-1932) s. 31-39; Posłowie s. 40.

\section{Tyzenhauz Rajnold}

428. ZIEMCZONOK Józef: Twórczość Rajnolda Tyzenhauza [1830-1880]. Warszawa 2007 Katedra Białorutenistyki Uniw. Warszawskiego ss. 92, nlb. 1, il.

Pedagog.

\section{Więckowski Ryszard}

429. RYSZARD Więckowski [1935-2002]. Życie, twórczość i działalność pedagogiczna. Księga pamiątkowa dedykowana pamięci profesora Ryszarda Więckowskiego twórcy polskiej pedagogiki wczesnoszkolnej. Pod red. Anny Tyl i Anny Buły. Łódź 2007 Wydaw. Uniw. Łódzkiego ss. 253 , nlb. 2, tabl. 2.

Treść: Więckowska Zofia: Życie - twórczość i działalność Profesora Ryszarda Więckowskiego s. 9-49; Znaczenie dorobku Profesora Ryszarda Więckowskiego dla rozwoju pedagogiki wczesnoszkolnej w Polsce. Puślecki Władysław: Twórca polskiej pedagogiki wczesnoszkolnej s. 53-65; Frycie Stanisław: Wkład Profesora Ryszarda Więckowskiego w modernizację kształcenia wczesnoszkolnego w latach 70. i 80. XX wieku s. 67-78; Ratajek Zdzisław: Dominująca rola edukacji wczesnoszkolnej w reformowaniu polskiego systemu oświatowego w świetle dokonań naukowych, organizacyjnych i dydaktycznych Ryszarda Więckowskiego na Ziemi Świętokrzyskiej w latach 1970-1989 s. 79-91; Włoch Stanisław: Aspekty rozwojowe dziecka w twórczości Ryszarda Więckowskiego s. 93-100; Kwaśniewska Małgorzata: Nauka pisania w dorobku naukowo-badawczym Profesora Ryszarda Więckowskiego s. 101-112; Wolny Irena: Kształcenie nauczycieli według koncepcji Profesora Ryszarda Więckowskiego s. 113-121; Marek Elżbieta: Działalność redakcyjna Profesora Ryszarda Więckowskiego s. 123-146; Więckowska Z.: Bibliografia dorobku naukowego i organizacyjnego Profesora Ryszarda Więckowskiego s. 147-253.

\section{Zakrzewska Zofia}

430. KOSMALA Włodzimierz: Wspomnienie o Zofii Zakrzewskiej [1916-1999]. Rocz. Hist. Harcerstwa. [T.] 3: 2007 s. 101-109. 


\title{
Żmichowska Narcyza
}

431. ZWOLIŃSKA Barbara: O Narcyzie Żmichowskiej [1819-1876]. Szkic do portretu nauczycielki i pisarki. W: Księga Janion. Oprac. Zbigniew Majchrowski i Stanisław Rosiek. Gdańsk 2007 s. $437-456$.

\section{DZIEJE OŚWIATY POZASZKOLNEJ}

\author{
1. Oświata dorosłych
}

432. MAŁY skrawek wolnej Polski. Szkoła Spółdzielcza dla Dorosłych Związku Spółdzielni Spożywców RP „Społem” na Lubelszyźnie 1940-1953. Zespół aut. Zofia Olszakowska-Glazer [i in.]. Warszawa 2007 MHPRL ss. 140, il. MHPRL. Zakł. Historii Ruchu Lud.

W Łysołajach.

\section{Biblioteki}

433. BIBLIOTEKI Leszna. Historia i współczesność. Materiały z konferencji w dniu 12 maja 2005 r. Pod red. Janiny Małgorzaty Halec. Leszno 2007 Stow. Bibliotekarzy Pol. Zarząd Oddz.; Miej. Bibl. Publ. im. Stanisława Grochowiaka. Wydaw. Cicer ss. 131, nlb. 4, il.

Z treści: Halec J. M.: Wprowadzenie s. 7-8; Stachowiak Aleksandra: Biblioteka gimnazjum leszczyńskiego w XVI-XIX wieku s. 9-16; Chrostecka Krystyna: Biblioteka Pedagogiczna w Lesznie. Zarys dziejów s. 29-39; Dzikowska Krystyna: Szkolne biblioteki we współczesnym Lesznie s. 41-57; Szczygieł Hanna: Leszczyńskie szkoły wyższe i ich księgozbiory s. 59-78.

434. DZIENIAKOWSKA Jolanta: Biblioteka dla nauczycieli kuratorium szkolnego poleskiego w Brześciu nad Bugiem (1927-1939). Prz. Hist.-Ośw. R. 50: 2007 nr 1/2 s. 133-148.

435. DZIENIAKOWSKA J.: Biblioteka Ministerstwa Wyznań Religijnych i Oświecenia Publicznego (1917-1939). Rocz. Bibliot. R. 51: 2007 s. 145-168, sum.

436. JARCZYK Aleksandra: Polskie biblioteki gimnazjalne w województwie śląskim w latach 1922-1939 oraz ich rola w kształtowaniu kultury czytelniczej młodzieży. Katowice 2007 Wydaw. Uniw. Śląskiego ss. 236, nlb. 4, sum., Zsfg. (Prace Naukowe Uniwersytetu Śląskiego w Katowicach; nr 2529).

437. JUŚKO Edmund: Biblioteki w szkołach powszechnych powiatu tarnowskiego w okresie międzywojennym. Arch. Bibl. i Muzea Kośc. T. 86: 2007 s. 107-116, Zsfg.

438. KARDYŚ Piotr: Izba Pamięci księdza profesora Włodzimierza Sedlaka [1911-1992] i jej rola w edukacji regionalnej. Prz. Hist.-Ośw. R. 50: 2007 nr 3 s. 179-183.

W Miejskiej Bibliotece Publicznej w Skarżysku-Kamiennej. 


\title{
VI. DZIEJE RUCHU NAUCZYCIELSKIEGO
}

\author{
1. Opracowania ogólne
}

439. CIEŚLA Andrzej: Związek Nauczycielstwa Polskiego i jego poprzednicy na Pomorzu w latach Drugiej Rzeczypospolitej. W: Nad Bałtykiem. W kręgu polityki, gospodarki, problemów narodowościowych i społecznych w XIX i XX wieku. Księga jubileuszowa poświęcona profesorowi Mieczysławowi Wojciechowskiemu. Zbiór studiów Pod red. Zbigniewa Karpusa, Jarosława Kłaczkowa, Mariusza Wołosa. Toruń 2005 s. 269-276.

440. DOROSZEWSKI Jerzy: Słownik biograficzny nauczycieli miasta Lublina w latach 1918-1939. Lublin 2007 Lubelskie Tow. Nauk. ss. 272, il.

441. GRĘDZIK-RADZIAK Agnieszka: Polscy nauczyciele z byłych ziem wschodnich II Rzeczypospolitej, ofiary terroru sowieckiego w latach 1944-1949 - deportowani, więzieni, zamordowani. Prz. Hist.-Ośw. R. 50: 2007 nr 1/2 s. 149-185.

442. KORBA Nina: ZNP ma już 100 lat. Z historii Związku Nauczycielstwa Polskiego 1905-2005. Merkuriusz Eęczyński. Nr 17: 2004 s. 24-26.

443. NOWY Sącz w stuletniej historii Związku Nauczycielstwa Polskiego. Praca pod red. Ireny Cepielik. Nowy Sącz 2005 Oddz. Miej. ss. 195, nlb. 3, il. Zw. Nauczycielstwa Pol.

Rec.: Kruczek Maria, Rocz. Sadec. T. 35: 2007 s. 363-366.

444. ROMANIUK Zbigniew, Usakiewicz Jarosław: Związek Nauczycielstwa Polskiego w Brańsku i okolicach. Brańsk 2006 Oddz. Zw. Nauczycielstwa Polskiego; przy współpr. Tow. Przyj. Brańska ss. 138, il.

XX w.

445. SOWADA Renata: Dziesięć lat Oddziału Towarzystwa Nauczycieli Bibliotekarzy Szkół Polskich w Częstochowie. Almanach Częstochowy. [T. 20]: 2007 s. 274-282.

Lata $1997-2007$.

446. SZCZĘŚSIAK Henryk, Szcześniak Waldemar: Zarys dziejów ZNP w Łukowskiem, 1905-2005. Łuków 2007 ZNP. Oddz. Krzywda, Łuków, Gmina, Stoczek Łukowski, Trzebieszów ss. 564 , il.

\section{Pamiętniki nauczycieli}

447. CZARNUCH Zbigniew: Osiem gawęd o moim zielonogórskim pedagogicznym raju. (Cz. 3). Studia Ziel.-Górs. T. 13: 2007 s. 227-243.

Wspomnienia z 1. 1961-1968; Cz. 1. Tamże. T. 11: 2005.

448. FALSKA Maria: Nasz dom. Zrozumieć, porozumieć się, poznać. Wybór i oprac. Marta Ciesielska, Barbara Puszkin. Warszawa 2007 Muzeum Hist. m.st. Warszawy ss. 402, tabl. 24, il. Zakład Wychowawczy „Nasz Dom”. (Materiały Źródłowe; t. 1) (Z Kręgu Korczaka. Tematy, ludzie, dokumenty). 
Zbiór źródeł dotyczących Zakładu Wychowawczego „Nasz Dom” im. Maryny Falskiej w Warszawie obejmujący teksty wieloletniej jego kierowniczki i obecnej patronki (żyjącej w 1. 1877-1944) poświęcone powstaniu (w 1919 r.) placówki w Pruszkowie, przeniesieniu do stolicy w 1928 r., jej organizacji i pracy, wspomnienia wychowanków oraz 60 listów z 1. 1915-1943.

449. FALSKI Marian: Z okruchów wspomnień. Oprac. i przypisy Maria Kossecka; wstęp Aldona Ossowska-Zwierzchowska. Bydgoszcz 2007 Wydaw. Uniw. Kazimierza Wielkiego ss. XXXVIII, 256, nlb. 1, il.

Wspomnienia pedagoga (1881-1974).

450. MITKOWSKA Jadwiga: Gdy kartki gubi kalendarz... Zespół red. Ewa Dąbek [i in.]. Pułtusk 2007 TPD. ZM-P s. 3-77, nlb. 1, il. Tow. Przyj. Dzieci. Zarząd Miej.-Pow. w Pułtusku.

Pamiętniki nauczycielki języka polskiego, żyła w 1. 1923-2002.

451. PATRO Gustawa Michalina: Autobiografia. Wągrowiec 2007 Agencja Reklamowa JT Belfer; nakł. Gustawy Patro ss. 44, il.

Wspomnienia z powiatu wągrowieckiego - o dzieciństwie w czasie wojny, powojennej edukacji, pracy w szkolnictwie, działalności literackiej i społecznej w ruchu regionalistycznym.

452. [ŻEBROK Jan]: Z pamiętnika śląskiego nauczyciela (na 125-lecie urodzin jego autora Jana Żebroka). [Wyd.] Jadwiga Miękina-Pindur. Kalendarz Cieszyński. [R. 24]: 2008 [dr.:] 2007 s. $112-118$.

Z 1. 1908 i 1931.

\section{ORGANIZACJE MLODZIEŻOWE}

453. BARTKOWIAK Przemysław: Struktura organizacyjna Zielonogórskiej i Gorzowskiej Chorągwi ZHP w latach 1975-1989. Studia Zach. Nr 9: 2007 s. 151-161, sum., Zsfg.

454. BARTKOWIAK P.: Zarys działalności szczepów harcerskich w Zielonej Górze w latach 1957-1989 na przykładzie Korczakowców i Makusynów. Studia Ziel.-Górs. T. 13: 2007 s. $165-173$.

455. BAZIUR Grzegorz: Harcerska działalność niepodległościowa w Prokocimiu (1946-1952). Annales APC. Folia 43: Studia Historica. [T.] 6: 2007 s. 195-234.

456. BAZIUR G.: Konspiracyjne organizacje młodzieżowe nawiązujące do tradycji piłsudczykowskiej w województwie krakowskim (1945-1950). Sowiniec. Nr 30: 2007 s. 27-58.

457. BAZIUR G.: Konspiracyjny Związek Harcerstwa Polskiego - Polska Straż Przednia jako przykład kontynuacji walki Szarych Szeregów w latach 1945-1949. Dzieje Najn. R. 39: 2007 [nr] 1 s. 61-92, sum.

458. BĄK Piotr: Zakopiańskie Harcerstwo na szlaku niepodległości 1980-1989. W: Drogi do niepodległości. Red. Jerzy Zacharko. Zakopane 2005 s. 300-357.

459. BEDNARSKI Mariusz D[ariusz]: Powszechna organizacja „Służba Polsce” w Lubelskiem (1948-1955). Radz. Rocz. Hum. T. 5: 2007 s. 156-189.

460. BEDNARSKI Waldemar Wojciech, Bednarski Mariusz Dariusz: Brygady rolne powszechnej organizacji „Służba Polsce” na Zamojszczyźnie w latach 1951-1955. Res Historica. T. 23: 2006 s. 285-305.

461. BRUZIEWICZ-MIKŁASZEWSKA Barbara, Karolonek Monika, Karolonek Gregor: Korporacje studenckie Wrocławia w XIX i XX wieku oraz próba przybliżenia sylwetki prof. Al- 
freda Meissnera w 120-stą rocznicę jego urodzin. W: Medycyna i farmacja XIX i XX wieku. Zagadnienia wybrane. Pokłosie Jubileuszowego Naukowego XX Krajowego Zjazdu Polskiego Towarzystwa Historii Medycyny i Farmacji. Pod red. Romana Meissnera. Poznań 2007 s. 23-35.

462. [BYŁY takie szczepy. Cz. 1]. Rocz. Hist. Harcerstwa. [T.] 3: 2007 s. 159-161. s. 161.

Treść: Szypowski Mirosław: „Pokrzywy” s. 159-160; „Makusyny” s. 160; Kiewicz Adam: „Błyskawica”

Szczepy harcerskie z 1. 50. XX w.

463. CHONIAWKO Andrzej: Kształtowanie świadomości historycznej młodzieży przez Związek Młodzieży Polskiej. Teki Archiw. T. 9: 2006 s. 23-32.

464. CZERNIAK Jan: O swojej drodze harcerskiej. Rocz. Hist. Harcerstwa. [T.] 3: 2007 s. 117-126. Wspomnienia z 1. 1932-1947.

465. DOBROŃSKI Aleksander: Udział harcerzy białostockich w czynie niepodległościowym (1917-1920). W: Lata Wielkiej Wojny. Dojrzewanie do niepodległości 1914-1918. Pod red. Daniela Grinberga, Jana Snopko, Grzegorza Zackiewicza. Białystok 2007 s. $463-477$.

466. DOKUMENTY do dziejów harcerstwa polskiego z lat 1942-1996]. Rocz. Hist. Harcerstwa. [T.] 3: 2007 s. 133-145.

467. EYCHLER Krzysztof: Harcerstwo Polskie („Hufce Polskie”) 1939-1944. Rocz. Hist. Harcerstwa. [T.] 3: 2007 s. 19-32.

468. FARBOTKO Władysław: Klub Filatelistów Polskiej YMCA w Łodzi. Z historii łódzkiej filatelistyki. Hist.-Badawczy Biul. Filat. R. 47: 2006 nr 1/2 s. 29-30.

469. GŁOWACKA-SOBIECH Edyta: Zjazd Łódzki i odrodzenie Związku Harcerstwa Polskiego w 1956 roku. Biul. Hist. Wychowania. 2005/2006 [dr.:] 2007 [nr] 1/2 s. 95-104.

470. HARCERSKI słownik biograficzny. T. 1. Pod red. Janusza Wojtyczy. Warszawa-Łódź 2006 Muzeum Harcerstwa; Marron Edition ss. 263, nlb. 1, tabl. 12, il.

471. HAUSNER Wojciech: Żółte barwy Bronowickich Harcerzy (1963-1975). Bron. Zesz. Hist.-Liter. Z. 24: 2007 s. 60-64.

472. HUK Andrzej: Krótka historia przemyskiej „Czarnej Trzynastki”. Kresy Poludn.-Wsch. R. 2: 2004 nr 1 s. 247-260.

Drużyna harcerska powstała w $1981 \mathrm{r}$.

473. JUREK Krzysztof: Lilijka i łódka. Historia harcerstwa łódzkiego do 1939 roku. Łódź 2007 Piątek Trzynastego Wydaw. Michał Koliński i Michał Wiercioch ss. 168, tabl. 16, il.

Rec.: Nartonowicz-Kot Maria, Rocz. Łódz. T. 54: 2007 s. 279-282.

474. KANTOR Ryszard: Koła krajoznawcze młodzieży szkolnej (1920-1950). Małopolska. [T.] 9: 2007 s. 181-184.

475. KIEŁB Zbigniew: Powstanie i organizacja Niezależnego Zrzeszenia Studentów UMCS w świetle akt lubelskiego oddziału Instytutu Pamięci Narodowej. W: Pamiętnik VIII Ogólnopolskiego Zjazdu Studentów Archiwistyki. (Archiwista w świecie źródeł historycznych). Lublin, 28-29 kwietnia 2005. Pod red. Janusza Łosowskiego. Lublin 2007 s. 237-249.

476. KIEWICZ Adam: Rok pierwszy dolnośląskiego harcerstwa. Rocz. Hist. Harcerstwa. [T.] 3: 2007 s. 33-44.

Okres 1945-1946. 
477. KIJOWSKI Maciej: Rzeszów, 17 listopada 2006 r. Sympozjum z okazji 100 rocznicy powstania skautingu. Rocz. Hist. Harcerstwa. [T.] 3: 2007 s. 153-154.

478. KOZIMALA Irena: Lwowska Chorągiew Harcerzy ZHP w latach 1921-1939. Przemyśl 2007 Państ. Wyższa Szkoła Wschodnioeuropejska ss. 465, tabl. 16, il. Państ. Wyższa Szkoła Wschodnioeuropejska w Przemyślu.

479. KRAKOWSKI Shmuel: Organizacje młodzieżowe w getcie łódzkim. W: Fenomen getta łódzkiego 1940-1944. Pod red. Pawła Samusia, Wiesława Pusia. Łódź 2006 s. 281-286.

480. KRAKOWSKI Stanisław: Harcerze w Przemyślu w latach 1944-1950. Kresy Poludn.-Wsch. R. 2: 2004 nr 1 s. 261-276.

481. KRONIKA Czeladzkiego Harcerstwa 1913-2005. T. 1. Oprac. red. Artur Rejdak, Jerzy Krzemień. Czeladź 2006 Stow. Miłośn. Czeladzi ss. 201, il.

482. „KRONIKA Wołomina” drużyny harcerek „GWIAZDY” z 1949 r. [Wyd.] Janusz Bublewski. Rocz. Wołom. T. 3: 2007 s. 203-215.

483. KRÓL Joanna: Problem religii i edukacji religijnej w ideologii wychowawczej Związku Młodzieży Polskiej (1948-1956). W: Religia jako źródło inspiracji w polskiej myśli politycznej XIX-XXI wieku. Pod red. Tomasza Sikorskiego, Adama Wątora. Szczecin 2007 s. 357-367.

484. KRYPTONIM „Wasale”. Służba Bezpieczeństwa wobec Studenckich Komitetów Solidarności 1977-1980. Wybór, wstęp i oprac. Łukasz Kamiński i Grzegorz Waligóra. Warszawa 2007 IPN-KŚZpNP ss. 517, nlb. 3, tabl. 28. IPN-KŚZpNP. (Dokumenty; t. 18).

485. KUBIAK Bronisław: Harcerski zostanie krzyż. Wspomnienia. Łódź 2006 Wydaw. Wing ss. 99 , nlb. 1 , il.

Relacja z harcerskiej służby autora - harcmistrza (ur. 1926) od wstąpienia do hufca w Zgierzu w 1937 r., poprzez Tajną Organizacje Młodzieżową „Brzask” w czasie II wojny światowej, powojenną pracę ponownie w Zgierzu (do likwidacji ZHP w 1950 r.) i w reaktywowanym harcerstwie łódzkim (do 1964 r.).

486. LECIEJEWSKA Katarzyna: Historia harcerstwa w Zakopanem w latach 1913-1939. Toruń 2007 Wydaw. Nauk. Grado ss. 169, il.

487. LIS Michał: Harcerstwo na Śląsku Opolskim jako obszar zainteresowania konsulów generalnych RP w okresie Republiki Weimarskiej. W: Księga jubileuszowa dedykowana profesorowi Romualdowi Gellesowi w sześćdziesiątą piątą rocznicę urodzin. Studia i szkice z historii, stosunków międzynarodowych i politologii. Wrocław 2006 s. 201-212.

488. MAŁSZYCKI Dariusz: Harcerstwo gdyńskie w latach 1928-1939. Rocz. Gdyń. Nr 18: 2006 s. $155-174$.

489. MUSZYŃSKI Wojciech J., Persa Jacek T.: II Rzeczpospolita korporancka. Działalność i oblicze ideowe. Glaukopis. Nr 1: 2003 s. 7-60.

Korporacje studenckie.

490. OJCZYŹNIE - wsi - sobie. W 50 rocznicę powstania Związku Młodzieży Wiejskiej na Rzeszowszczyźnie. Red. Stanisław Kornak, Maria Ożóg, Edward Ożóg. Rzeszów-Łąka 2007 Wydaw. AWR Atrium ss. 72, il.

491. ORGANIZACJE studenckie Politechniki Łódzkiej w latach 1945-1950 we wspomnieniach]. Zesz. Hist. Politech. Eódz. Z. 5: 2007 s. 165-174. 
Treść: Missala Tadeusz: Początki Bratniaka przy Politechnice Łódzkiej s. 165-166; Missala T.: Pierwsze niepokoje i manifestacje s. 167; Niezgodziński Michał E.: Działalność wydawnicza w początkach Politechniki Łódzkiej s. 169-170; Bogusławski Lech: Wspomnienia z działalności w Komisji Wydawniczej Bratniej Pomocy Studentów PŁ s. 171; Bogusławski L.: Wspomnienia z lat 1945-49, Bratnia Pomoc s. 173-174.

492. PO ZIEMI naszej roześlemy harcerzy... Z dziejów harcerstwa polskiego na Górnym Śląsku. Pod red. Krystyny Heskiej-Kwaśniewicz. Katowice 2007 Studio Noa Ireneusz Olsza; IPN ss. 368, il. IPN. Oddz. w Katowicach.

Materiały z konferencji, Katowice 28-29 listopada 2006 r.

493. ...POD rękę przez cały Mokotów. 40. rocznica przyjęcia przez Hufiec ZHP Mokotów imienia Szarych Szeregów. Warszawa-Ząbki 2007 Komenda Hufca ZHP Warszawa-Mokotów; Apostolicum ss. 311, il.

Księga pamiątkowa.

494. „POLSKĘ pięknić i uładzać...”. W 50. rocznicę powstania Związku Młodzieży Wiejskiej. Zred. Wojciech Borsuk. Warszawa 2007 MHPRL ss. 80. MHPRL.

Treść: Gmitruk Janusz: 50. rocznica powstania Związku Młodzieży Wiejskiej 1957-2007 s. 5-10; Tejchma Józef: Nasze pięćdziesięciolecie s. 13-21; Grabowicz Józef: Klimaty fenomenu ZMW s. 23-25; Markowicz Zygmunt: Czym wyróżniał się ZMW (1957-1976) s. 27-29; Gromkowa Krystyna: Widzieć i tworzyć przyszłość s. 31-33; Krzywdzianka-Wróblewska Halina: Dziewczęta i malwy s. 35-38; Socha Jan: Moja wspaniała przygoda s. 39-41; Rybczyńska Irena: Dwa razy do jednego worka s. 43-45; Łysek Jan: W deszczowy, jesienny wieczór s. 47-49; Woźniczko Joanna: Przyjacielska atmosfera s. 51-52; Borsuk W.: Złotymi zgłoskami s. 53-55; Oświadczenie Komitetu Przygotowawczego Krajowej Narady Młodzieży Wiejskiej, uchwalone w 1956 r. w Warszawie na spotkaniu inicjującym odrodzenie ZMW s. 57-63; Członkowie Komitetu Przygotowawczego Krajowej Narady Młodzieży Wiejskiej s. 64; Założenia ideowo-programowe, uchwalone 10-11 lutego 1957 r. przez uczestników Krajowej Narady ZMW s. 65-74; Centralne władze Związku Młodzieży Wiejskiej (stan na 30 kwietnia 1957 r.) s. 75-78.

495. POTKAŃSKI Waldemar: Robert Baden-Powell jako twórca światowego skautingu oraz polska koncepcja ruchu istniejącego w Galicji przed 1914 r. Czasy Nowożytne. T. 20: 2007 s. $102-114$.

496. ROSSMAN Jan: Harcerze w kampanii wrześniowej 1939 roku. Rocz. Hist. Harcerstwa. [T.] 3: 2007 s. 13-17.

497. RUTA Adam: Biblioteczka Harcerskich Drużyn Żeglarskich. Annales APC. Folia 47: Studia ad Bibliothecarum Scientiam Pertinentia. [T.] 5: 2007 s. 160-172, abstr.

Seria wydawnicza w 1. 1933-1938.

498. RZECZ o Związku Socjalistycznej Młodzieży Polskiej bez upiększeń, ale i bez negacji. Red. Daniela Mazur. Warszawa 2005 Kraj. Komisja Hist. Stow. „Pokolenia” ss. 285, nlb. 1, XII, il. Stow. „Pokolenia”. Kraj. Komisja Hist. (Z Dziejów Ruchu Młodzieżowego; 4).

499. RZECZKOWSKA Ewa: „My chcemy wolnej Polski!”. Tajne organizacje harcerskie na Lubelszczyźnie w latach 1944-1956. Glaukopis. Nr 7/8: 2007 s. 174-207.

500. SADOWSKA Joanna: ZMS wobec Marca 1968. Studia Polit. Nr 19: 2007 s. 273-310, sum.

501. SAMSONOWICZ Zdzisław: Wspomnienia o Straży Akademickiej Politechniki we Wrocławiu. Wyd. 2 popr. i uzup. Wrocław 2006 Oficyna Wydawnicza Politech. Wrocławskiej ss. 139, nlb. 1 , il.

Z 1. 1944-1956; Wyd. 1. 2002. 
502. SARAPATA Wilhelm: Bisko cztery lata prowadziłem wrocławską drużynę. Rocz. Hist. Harcerstwa. [T.] 3: 2007 s. 127-129.

Wspomnienia z 1. 1930-1939.

503. SERPUHAŬ Uladzìmìr: Belaruskiâ studènckiâ arganìzacyì Vilenskaga unìversìtèta (1919-1939). Białorus. Zesz. Hist. Nr 28: 2007 s. 54-68, streszcz.

504. STATUTY Koła Historyków Studentów KUL z okresu międzywojennego. Oprac. Andrzej Gładysz. Ibidem. T. 4: 2007 s. 73-91.

505. STOWARZYSZENIE Młodzieży Żydowskiej im. [Józefa] Trumpeldora w Polsce - Brith Trumpeldor (Bejtar). [Wyd.] Piotr Gontarczyk pt. Trumpeldorczycy czyli żydowski narodowy-radykalizm. Notatka z archiwum polskiego Ministerstwa Spraw Zagranicznych w sprawie żydowskiej organizacji narodowo-radykalnej. Glaukopis. Nr 2/3: 2005 s. 322-326.

Notatka z XI 1936 r.

506. SZAREK Jarosław: Nim powstał SKS. Biul. IPN. 2007 nr 5/6 s. 24-35.

Studencki Komitet Solidarności.

507. SZCZYPKA Andrzej: Organizacja Młodzież Wszechpolska na Politechnice Śląskiej w Gliwicach w latach 1946-1947. Rocz. Muz. Gliw. T. 20: 2006 [dr.:] 2007 s. 247-260, sum., Zsfg.

508. ZWIĄZEK Harcerstwa Polskiego na Kurpiowszczyźnie. Cz. 1. Zespół red. Zofia Topa, Jerzy Konkiel, Stanisław Dawidczyk. Ostrołęka 2005 Komenda Hufca ZHP; Tow. Przyj. Ostrołęki ss. 336, il.

Antologia wspomnień, XX-XXI w. 